\title{
Radiolysis of Actinides and Technetium in Alkaline Media
}

\author{
A. K. Pkgav \\ A. V. Gogolev \\ S. V. Krvitchkow \\ V. P. Shiov \\ V. N. Chulleor \\ L. I. Beilyacra \\ L. N. Astafurova \\ Pugainn rupdeny of Scinces: \\ hatiturs of Prinkes Cheringury \\ Mopecow, humite \\ Oome Pubdutad \\ Aupust 1996
}

Prepared for the U.S. Depatrient of Energy

Assistait Secretary for Emironmental Misnagement

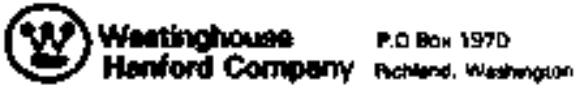

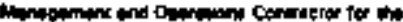

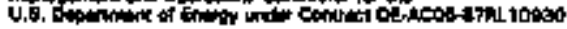




\section{RELEASE AUTHORIZATION}

Documont Humber: WiC-EP-090]

Documax Thte: Radiolysis of Actinides and Techet lun in Alkeline Med is

Aoberes One: $\quad \pi / 10 / 96$

Thts document was revilawed following the procedures described in WHC-CM+3.4 and is:

APPROVEO FOR PUELIC RELEASE

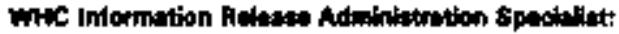

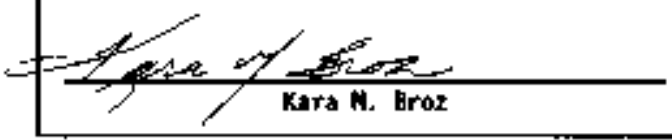

Jy7y 10,1996 


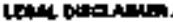

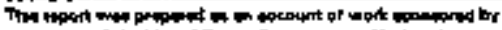

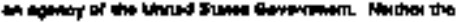

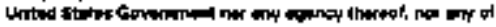

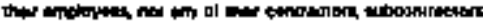

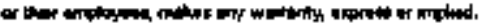

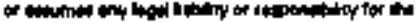

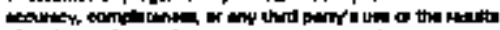

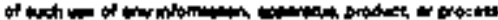

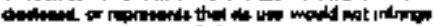

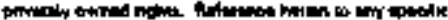

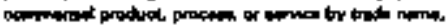

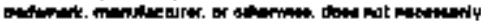

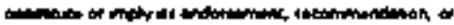

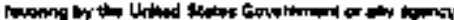

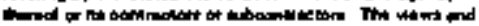

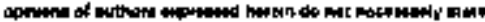

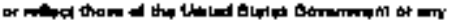
apenor dowed

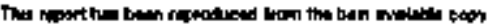

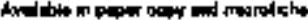

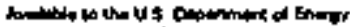

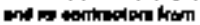

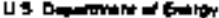

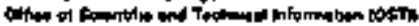

For mas

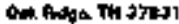

क1की काo-1401

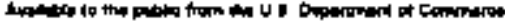

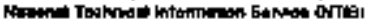

Btil Fort hone heed

Bpinglaty ve 2:161

mosi arditio

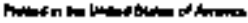

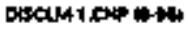




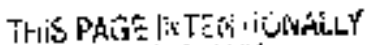

IEFT BUEN!K 


\section{ABSTRACT}

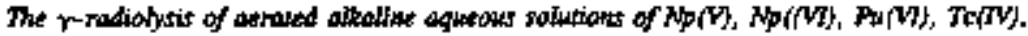

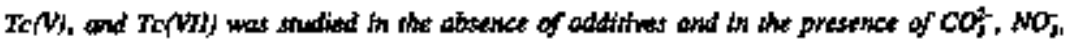

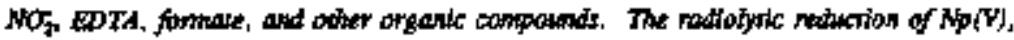

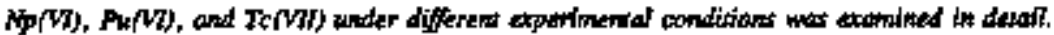

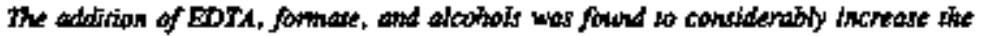

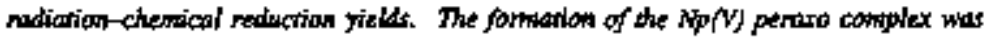

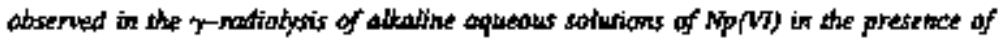
nivate. 
WHC-EP-0901

This pape interationally left blank. 


\section{CONTENTS}

1.0 INTRODUCTION $\ldots \ldots \ldots \ldots \ldots \ldots \ldots \ldots \ldots \ldots \ldots \ldots \ldots \ldots \ldots \ldots$

2.0 EXPFRMMENTAL MATERLALS AND METHODS $\ldots \ldots \ldots \ldots \ldots \ldots, 2-1$

3.0 GAMMLA RADIOLYSIS OF AQUEOUS ALKALINE SOLUTIONS OF NEPTUNIUM . . . . . . . . . . . . . . . . . . . . . . . . .

3.1 GABMLA RADHOLYYSLS OF ALKALINE AQUEOUS \$OLUTIONS OF NEPTUNTUM(V) IN THE ABSENCE OF ADDITVES . . . . . , 3-1

3.2 GAMOMA RADIOLYSIS OF ALKALNE AQUEOUS SOLUTIONS OF NEPTUMTIM(V) IN THE PRESENCE OF ADDTTVES $\ldots \ldots \ldots \ldots 3 \cdot 12$

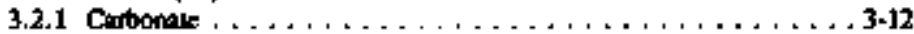

3.2 .2 Otganic Compownds $\ldots \ldots \ldots \ldots \ldots \ldots \ldots \ldots \ldots, \ldots \ldots$

3.1.3 Nitrite and Nitrate . . . . . . . . . . . . . . . . . . 3-18

3.3 GAMMA RADIOLYSIS OF ALKAJINE AQUEOUS SOLUTIONS OF

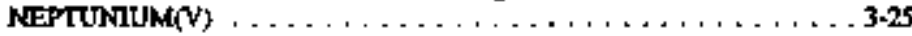

4.0 GAMMA RADIOLYSIS OF ALKALINE AQUEOUS \$SOLUTIONS OF PLUTONIIMA . . . . . . . . . . . . . . . . . . . . . . . .4-1

4.1 GAMMA RADIOLYSIS OF ALKALNE AQUEOUS SOLUTIONS OF PLUTONIUM JN THE ABSENCE OF ADDITTVES , . . . . , 4.1 4.2 GAMDSA RADIOLYSIS OF ALKALJNE AQUEOUS SOLUTJONS OF PLUTONITM IN THE PRESENCE OF ADDTIVES , . . . . . . . 4 ]

3.0 GAMMA RADIOLY\$SIS OF ALKALINE AQUEOUS SOLUTIONS DF TECHLNETIUM $\ldots \ldots \ldots \ldots \ldots \ldots \ldots \ldots \ldots \ldots \ldots, \ldots, \ldots, \ldots \ldots$ 5.1 RADIOLYTIC REDUCTION OF PERTECHNETATE , . . . . . , 5.1 \$.2 RADIOLYTC OXIDATTON OF Ta(UV) AND TO(V) HYDROXIDES , . . 5.5

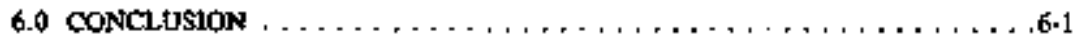

7.0 ACKNOWLEDGEMENTS $\ldots \ldots \ldots \ldots \ldots \ldots \ldots \ldots \ldots \ldots$

8.0 REFERENCES $\ldots \ldots \ldots \ldots \ldots \ldots \ldots \ldots \ldots \ldots \ldots \ldots \ldots \ldots$ 


\section{LIST OF FGURAS}

2-1 Opdeal Absomption Spectrum of the Propared Stock Np(VT) Solution in

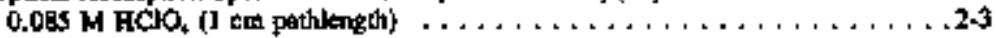

2-2 Optical Absoption Spectrun of a Prepared Slock Pu(VI) Solution in

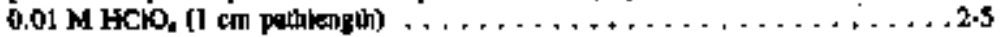

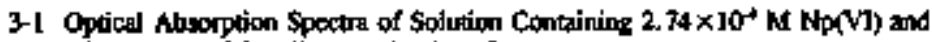

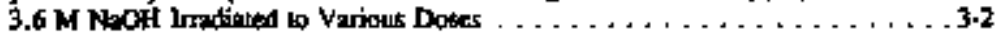

3.2 Dependence of Np(V) Concentration in $7 \mathrm{M}$ NeOH on Dose .......... . . 3-3

3.3 Dependence of Optisal Density a $275 \mathrm{~nm}$ for Alpling Solotions Comtaining $2.74 \times 10^{-4} \mathrm{M} N \mathrm{~N}(\mathrm{~V})$ ) and $7 \mathrm{M} \mathrm{NrOH}$ or Dose . . . . . . . . . . . . 34

3.4 Optieal Absorption Spectre of the Np(V) Perowo Complex in Solutions Conlaining $2.7 \mathrm{~A} \times 10^{-1} \mathrm{M} \mathrm{Np}(\mathrm{V}), 3.9 \times 10^{-1} \mathrm{M}, \mathrm{H}_{7} \mathrm{O}$, and $4.2 \mathrm{M} \mathrm{NaOH}$ After

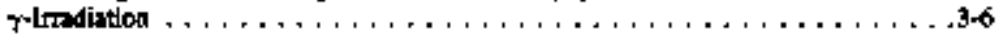

3.5 Optical Absomption Spectro of $2.74 \times 10^{4} \mathrm{M} N \mathrm{~N}(\mathrm{VI})$ and $7 \mathrm{M} \mathrm{NaOH} \ldots \ldots$

3.6 Opdeal Absorption Spectrom of the Sohuthon Prepared by Dissolution, in $2.1 \mathrm{M}$ EIClO, of Precipitales Oblained by Centrifupation Two Hours Alter Imatiation of $2.74 \times 10^{-1} \mathrm{M} \mathrm{Np}$ (V) and $7 \mathrm{M} \mathrm{NoOH}$ to $251 \times \mathrm{Gy} \ldots \ldots \ldots$

3.7 Opdinat Absomption Spectinum of the Solution Preparted by Dissolution, in $2.1 \mathrm{M} \mathrm{HClO}$, of Precipitales Oothined by Centrifugation 24 Hours After

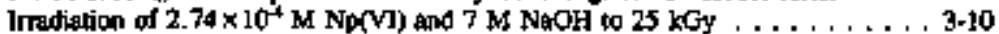

3.8 Optical Absompion Spectre of $3.56 \times 10^{-1} \mathrm{M} \mathrm{Np}(\mathrm{VI}), 0.67 \mathrm{M} \mathrm{Na} \mathrm{CO}_{3}$, and 2.4 M NrOH as a Fupction of Dase . . . . . . . . . . . . . . . . . . . 3-14

3-9 Dependence of $\mathrm{Np}(\mathrm{VI})$ Concentruion on Dose in $0.67 \mathrm{M} \mathrm{Na}_{1} \mathrm{CO}_{3}$ and

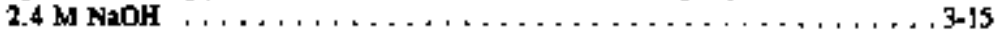

3-10 Depeature of Np(VT) Coneemration on Dove in 0.013 M EDTA and

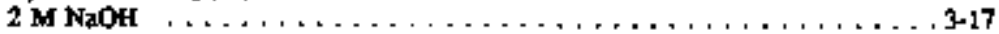

3-11 Optiegl Abeorption Spectre of NaOH, NaNO, NaNO, and $\mathrm{Np(VI)} \mathrm{Salutions;}$ Carbonde Complexes . . . . . . . . . . . . . . . . . . . . . . .

3-12 Cptichl Absorplion Specter of $\mathrm{NaOH}_{1}, \mathrm{NaNO}_{2}, \mathrm{NaNO}_{3}$, and Np(VT) Solutions; Fomation of Peroxa Complexes 


\section{LIST OF FIGURES (Condmed)}

3.13 Optica Abseaption Spectan of NaOH and Np(W) Sohutions $\ldots \ldots \ldots \ldots \ldots, 3-22$

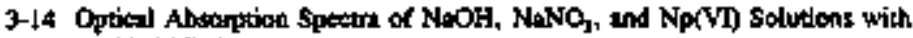

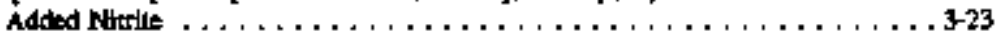

3-15 Optical Abeopthon Spean of NrOH, NaNO, and $\mathrm{Np}$ (VT) Solution will Added EDTA $\ldots \ldots \ldots \ldots \ldots \ldots \ldots \ldots \ldots \ldots \ldots \ldots \ldots, \ldots \ldots \ldots$

3-16 Optical Absorption Spectro of $\mathrm{NrOH}, \mathrm{Np}(\mathrm{V})$, and $\mathrm{Np}(\mathrm{VI})$ solutions $\ldots \ldots \ldots$ 3-26

3-17 Optical Abroption Spectrum of Dissolved Procipiate fiom lrmatiaked Np(V)

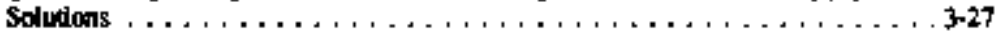

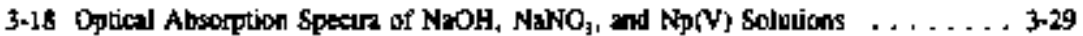

3-19 Optical Absorption Spectra of $\mathrm{NaOH}, \mathrm{NaNO}_{3} \mathrm{NaNO}_{2}, \mathrm{~Np}(\mathrm{~V})$, and $\mathrm{NprVI}$ )

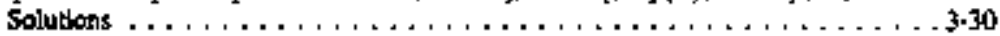

4.1 Optied Absoption Spectro of $\left(.9 \times 10^{-1} \mathrm{M}\right.$ Pu(VI) and $6.9 \mathrm{M}$ NaOH Solution as a Function of Dose $\ldots \ldots \ldots \ldots \ldots \ldots \ldots \ldots \ldots \ldots \ldots \ldots, \ldots, \ldots, \ldots$

4-2 Optical Atrsorition Siectra of $1.9 \times 10^{-4}$ M Pu(V) and I.3 M NaOH Solution as a Function of Dose $\ldots \ldots \ldots \ldots \ldots \ldots \ldots \ldots \ldots \ldots \ldots \ldots \ldots, \ldots, \ldots, 3$

4-3 Optical Absorption Spectrum of DAssolved Preciptakes from $10 \mathrm{kGy}$ lTadisted Pu(VD Solution $\ldots \ldots \ldots \ldots \ldots \ldots \ldots \ldots \ldots \ldots \ldots \ldots \ldots, \ldots \ldots$

4t Optical Absorption Spectroun of Dissolved Precipitales from 20 kGy Irradisted Fu(vT) solvcion $\ldots \ldots \ldots \ldots \ldots \ldots \ldots \ldots \ldots \ldots \ldots \ldots$

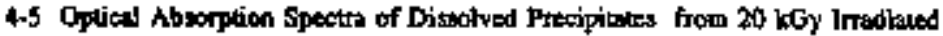

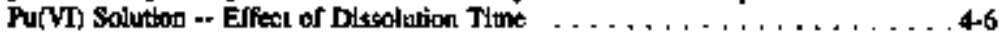

5-I Deperiftence of To0, Concentration on Dose in Aerated Aqueous Solution Containing 4 M NaOH and 0.04 M EDTA $\ldots \ldots \ldots \ldots \ldots \ldots \ldots, \ldots, 5$

5-2 Dependence of Technetum Concentation on Dose for \$uspensions of $\mathrm{TcO}_{3}, \mathrm{nH}_{2} \mathrm{O}$ a Varlous $\mathrm{NaOH}$ Concentrationis $\ldots \ldots \ldots \ldots$

5-3 Dependence of Technetium Contextration on Doye for Suspenslous of $\mathrm{Tc}_{2} \mathrm{O}_{2} \cdot \mathrm{nH}_{3} \mathrm{O}$ at Various $\mathrm{NaOH}$ Conceprations 


\section{LIST OF FIGURES (Conitnmed)}

5.4 Deptendetice of Tewhetium Concentration on Dose for Strpensions of

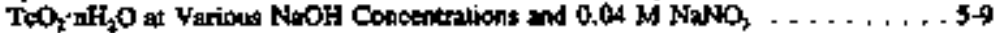

5.5 Dependence of Teclantirum Conoentation on Doxe for Suspensicaly of

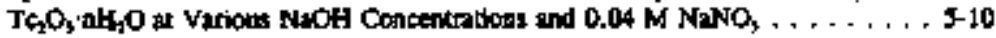




\section{UST OF TABLES}

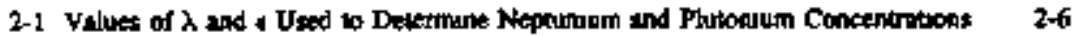

3-I Radison-Clonkgal Yualde of Np(VI) Reduction, G-Np(VI)], in herated Altihe Aggrows Soludunt

4-1 Intal Ratation-Chemural Yields of Pu(VI) Retukcuon, G[-PurV])] in Aeribed Allaline Aguepus Solutions

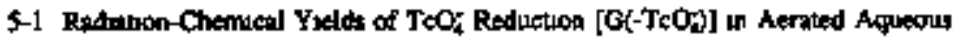
Sohubons

5-2 Rates, $Y$, of ToO, vH,O Post-Rodugtion Oxidahon al Vanows NaOH Concebrations and Absonbed Dasey

5-3 Rates, V, of $\mathrm{Tc}_{7} \mathrm{O}, \mathrm{nH}+\mathrm{O}$ Posi-Radiation Orudatron at Varkous $\mathrm{N}-\mathrm{OH}$ Concentrations and Absoted Doses

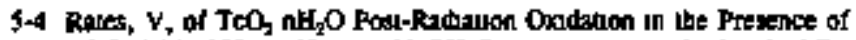
$004 \mathrm{M} \mathrm{NaNO}_{3}$ at Varous NaOH Concentrobons and absorbed Doses

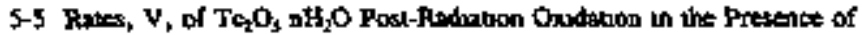
0 04 M NaNO, at Vanouts NaOH Concentramons and Absorbed Doses

5-6 Rates, $\mathrm{V}_{+}$of $\mathrm{TcO}_{2} \mathrm{nH}, \mathrm{O}$ Fod-Radanon Oxdation in the Presense of $005 \mathrm{M} \mathrm{NaNO}$ at Variout $\mathrm{NaOH}$ Concentrataons and Absorbed Doses

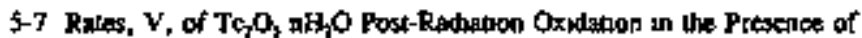

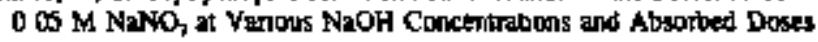

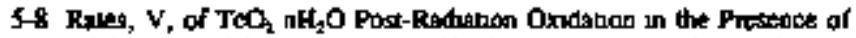
it of $\mathrm{M} \mathrm{Na}_{2} \mathrm{CO}_{3}$ at Vanows NaOH Coucentranons ard Abrorbed Doses

5-9 Rules, V, of $\mathrm{Ta}_{\mathrm{g}} \mathrm{O}, \mathrm{nH}, \mathrm{O}$ Post-Radiation Oxidation m the Presence of o OS M $\mathrm{Na}_{2} \mathrm{CO}_{1}$ at Varous NoOH Concentrathons and Abrorted Doses 
This page inkitiogally kf bank

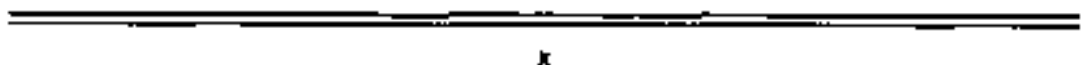




\section{RADIOLYSS OF ACTDNIPES AND TECENETIUM IN ALKALINE MEDIA}

\section{1.* INIRODUCTION}

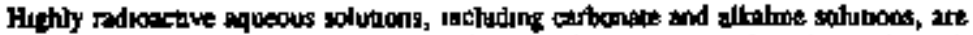

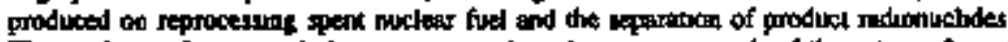

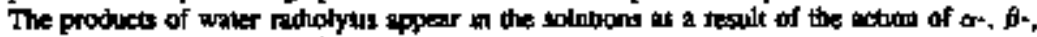

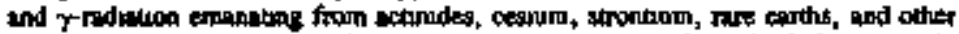

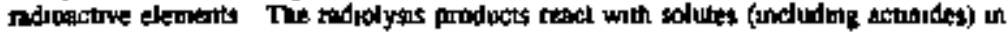

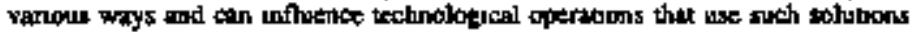

The radrosctuve wallo stored un underjound tanits at the Hanford Site are alloplene To manage weth wate successfully, it is tecessary to know the feetures of radiolytic conversions

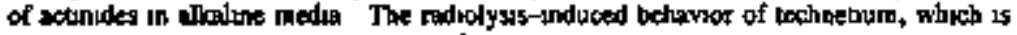
present in the wate solutions, is also of contien

Information on the radialuon-chemical properties of actumds in the $V, I V$, and UI valeni

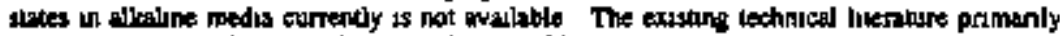

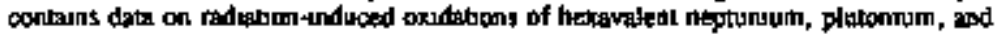
anesciem wo thetr nespectuve heptavalent stakes in alkaline solutions, reduetiog of heptavalent slates in the some sohtwons, oxidation of Am(III) in erbonate meda, and reacovily of scansde cons kowads wrter radtofysy produca and certan other free radicals in carbonale and alkaline solotions (Plkeev et al 1983 and Peretrukhun at al I995) Informotican on the

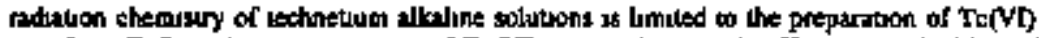
rons from TeO, and some properties of Te(VT) ions within a wode pH range sturted by pulse radrolyss (Peretrukthen ta al 1995)

The progent work a dewoted to the study of $\gamma$-radiolyss of alkaline and carbonale-allalide aqueous wolotont of penta- atod hexayalent nephoum, hexavalent plutonium, and letra-,

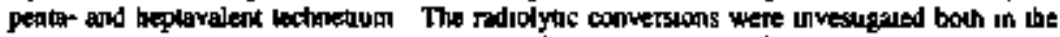
absence of any addowes and $u$ the presence of $\mathrm{NO}_{3}, \mathrm{NO}$, EDTA', and bethes organe adduver

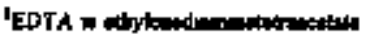


This page intentimually kfil blank. 


\section{2,0 EXPERMIZNTAL MATERIALS AND MISITODS}

Double and soretbes triple distilled water and chenieslly pure srode sodium hydroxide were used to pectperte the soluthoss. A portion of the initial NaOB solution mas first $\gamma$-irrodiated lo bout 70 LGy dose to temove posible ofpanic mikroimpuritios. Optical

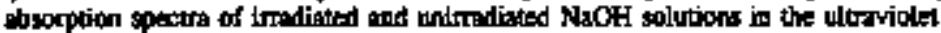
(UV)-rogion at wavelength, $\lambda$, preater thol $230 \mathrm{~nm}$ wer withally the same and did not conntin bands that could be attributtis bo organic impurities. Pure-for-analyas grode formic

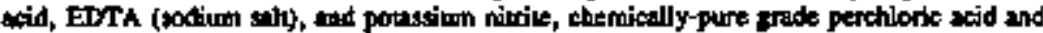

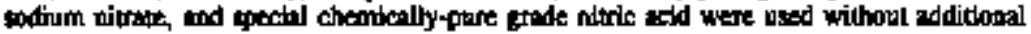

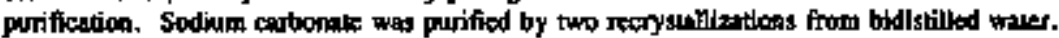

The stock solution of neptunyt perplalorate was preprared by the tollowing lown procedute.

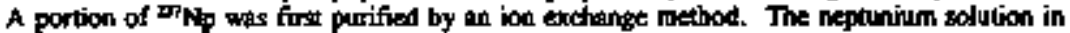
nitric acid that deagrbed from the polpmn wras fraporated o datip alts three times with perchkric acid. The residue was dissolved in $0.085 \mathrm{M} \mathrm{HCK}_{4}$, ther stomed in the dark. Spectrophotometrle andysis in the renge of 350 to $1,300 \mathrm{~nm}$ showed that the colntion

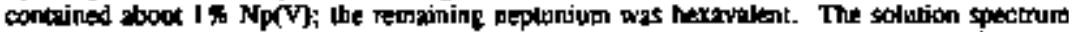
is shown in Figure 2-1. The Np(VT) concentration in the sock solotion was $1.4 \times 10^{-2} \mathrm{M}$. Tue neptudiom concentration was detervioned by complexonsetric titrotion wifl prediminary reduction to the teiravident rate.

Allaline Np(VI) soltulions were prepaned by adding mesured anounts of the stock

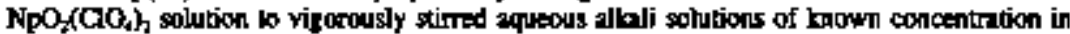
volumetrie flasks. The flalks bea were flled to volume wilh the stock allolt solution. The maximum Np(VT) concentrition in albaline solulions used in the experiments was $5.8 \times 10^{4}$

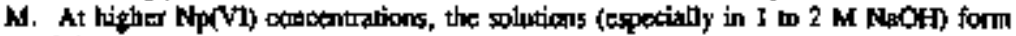
precipipives.

Perchloric acid colntions of $\mathrm{Ng}$ (V) were chtained by two thethods. The first coosisted of rirradiation of the stock perchloric acid solutions of Np[VT). Neptumium(V) is the product of radiolytic Np(VT) resuction in acid aqueous solutions (Piken th al. 1983). Spextrophovometry shomed thex only $\mathrm{Np}(\mathrm{V})$ is present in the solution after retreadiation to a dose of about 60 boy. Adling the prepined acid Np(V) solution to the alletine bolntiosts

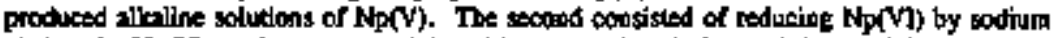

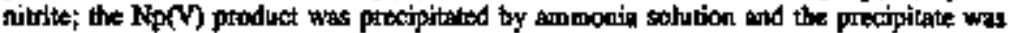
scparrted by contrifugation. The NyrY) procipitale was woshad twice with ice-cold bididilled water. The precipitate then oras disolved is 2 small excess of $\mathrm{HClO}_{4}$ solution.

The rtock perchloric acid solotions of hexavient plulonhum were preponed by the following

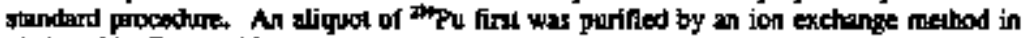

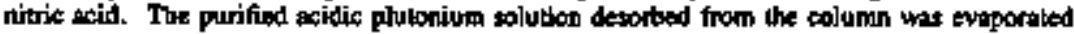

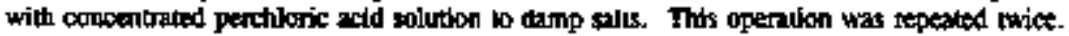


Figure 2-1. Optical Abuorption Spectrum of Le Prepared Srock Np(VI) Solution in $0.085 \mathrm{M} \mathrm{HClO}$, (1 $\mathrm{cm}$ pathiength).

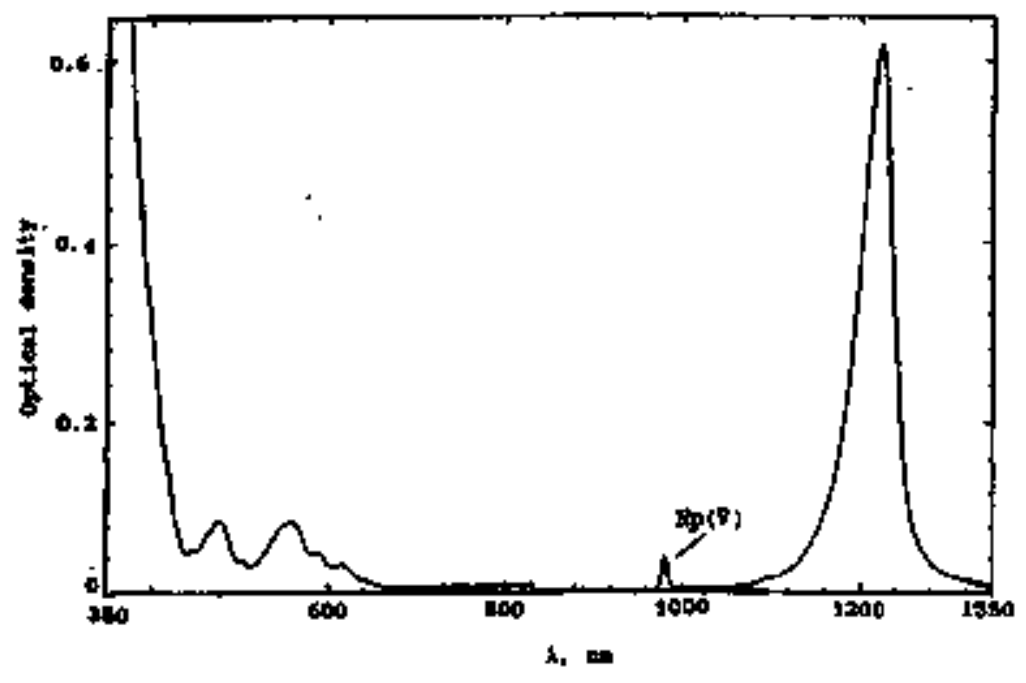




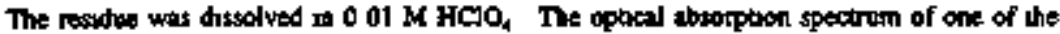
solutionl prepared is stown in Figure 2-2 The spectrun shows thrt only Pu(VI) is present

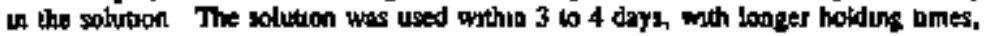

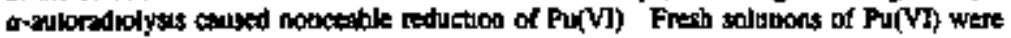

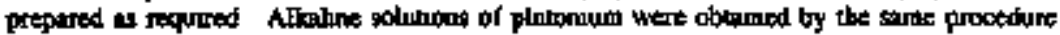

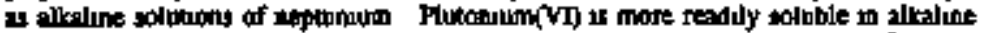
solutbons the acoponium(

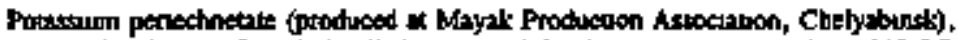

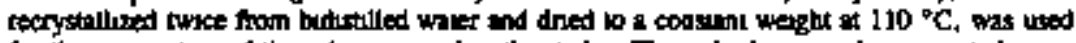
for the ptaperation of the solutions uned in the stady Thus all also served as an intial comporind for syothess of Tc(IV) and Te(V) orides

All the expenmetsis wete ponductiad in actated solobons

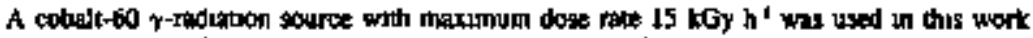

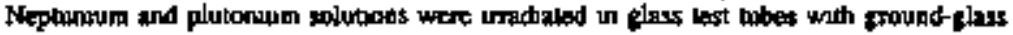
stopipers The test tubes were placed in th alass belat held in a metal contalner All

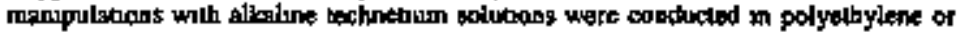

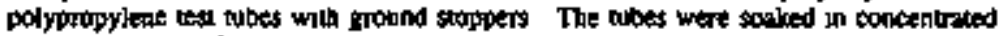

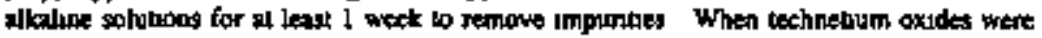

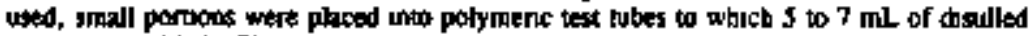

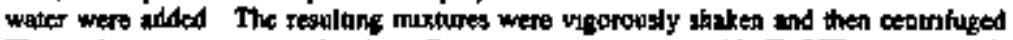

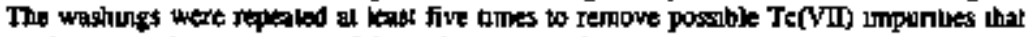
magl appear dunis slorse of the lechnetrum oxide spacimeas

Dosimetry was performed using doametric solntams of feriosulfale (for dose rates ranging

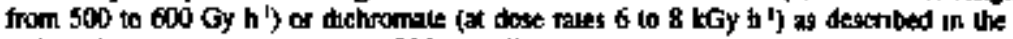

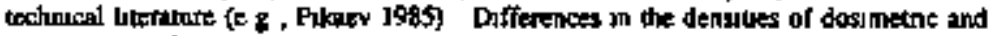

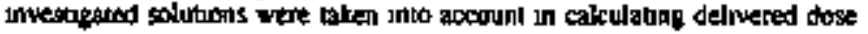

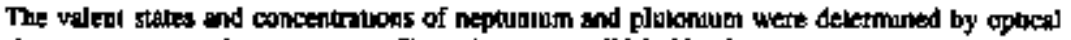
absomplion spactrophotometry A Stumadzu model UV-3100-PC spoctuopholometer (lapan) was used The wevelengths ( $k$ ) and molar exunction coefificatits (1) uged for these measurements are shown in Tible 2-1 Nepaunjum(S) un alkaline solution has no opucal absorption hands butatle for inetsurements Therefore. NP(V) was meawred by

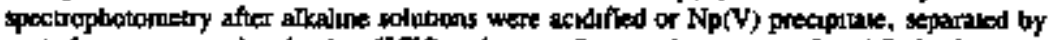

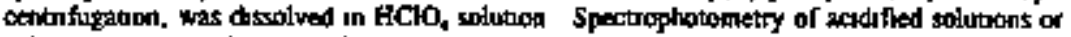
solsts also was usod to adonthfy Pa(TV) 
Figure 2-2. Opting Absonption Specinum of a Prepared Stock PUCVD Solution to $0.01 \mathrm{M} \mathrm{HCO}_{4}$ (I sm pathlength).

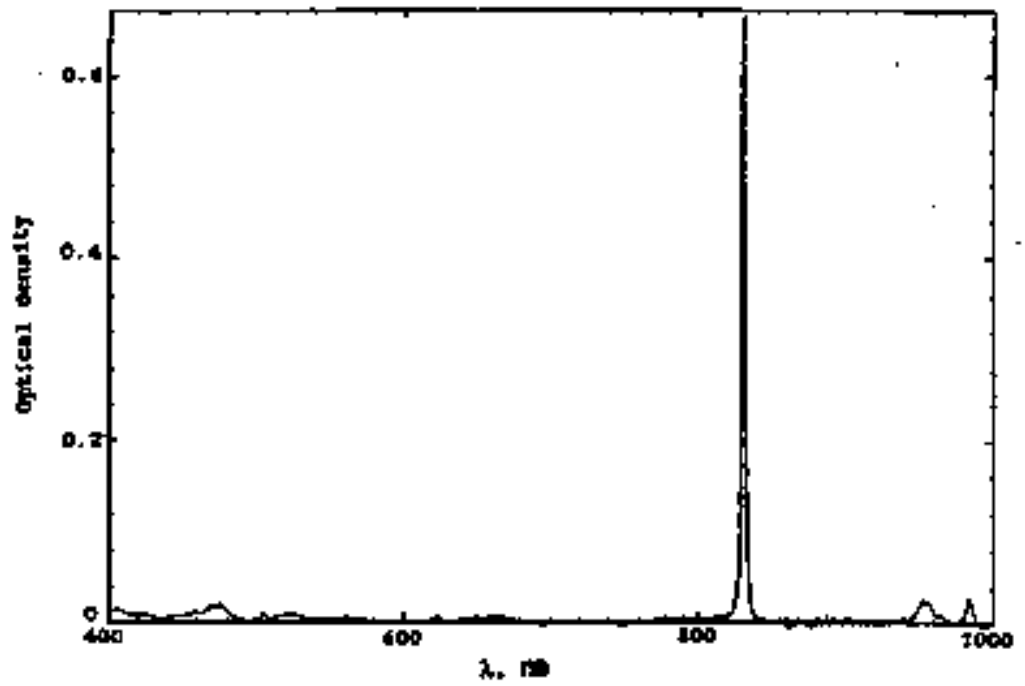


Table 2-L. Values of $\lambda$ and $\epsilon$ Used k Determine Keptukium and Pluknium Concentrotbon!. 1.2 .2

\begin{tabular}{|c|c|c|c|}
\hline 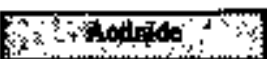 & Tedinat & $x_{1}$ & a, $34 x^{3}$ \\
\hline No(V) & $2 \mathrm{MHCO}$ & 1223 & 45 \\
\hline$N_{p}(\sqrt{T})$ & I M Nath & 275 & 2,400 \\
\hline $\mathrm{Np}$ (VI) & I M NaOH & 273 & $2,500^{\circ}$ \\
\hline Np(V) & 2 M NAOH & 275 & $2,550^{\circ}$ \\
\hline Np(V) & A M $\mathrm{MOH}$ & 275 & $2, \overline{450^{\circ}}$ \\
\hline $\mathrm{Np}(\mathrm{VI})$ & $6 \mathrm{MNOOH}$ & 275 & $2, \mathrm{BO} 00^{4}$ \\
\hline Np(VI) & $8.5 \mathrm{M} \mathrm{NaOH}$ & 275 & $2,850^{\circ}$ \\
\hline Np(V) & $2 \mathrm{M} \mathrm{HClO}_{4}$ & 982 & 400 \\
\hline Np(TV) & $2 \mathrm{M} \mathrm{HClO}$ & 962 & 162 \\
\hline Pu(v) & $6-8 \mathrm{AC}$ HC. & 831 & 500 \\
\hline Pu(v) & $\bar{M} \mathrm{~N}$ \&OH & $\overline{275}$ & 2,000 \\
\hline Pu(TV) & $6.8 .5 \mathrm{M} \mathrm{HClO}_{4}$ & $475-477$ & 50 \\
\hline Pu(IV) & $6-7.5 \mathrm{M} \mathrm{ENO}_{3}$ & $475-47$ & Bषे \\
\hline
\end{tabular}

Nows:

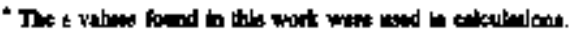

(C) (1960)

2 MDrdurvidy at al. (1979)

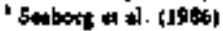

Metbods based on lise measurements of $\beta$ stadiogativity were used to determine the concentintions of "Ic in solution. The messumfunts were conducted using the aubmalic

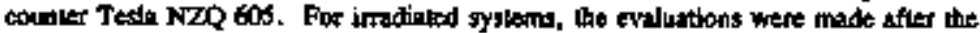

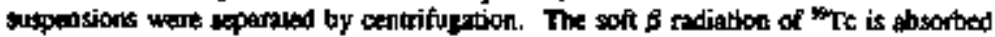
strongly by the alkgil alis. Corroction for thil self-gbsorpton was made by meihods

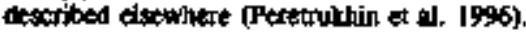

Dispetse particles wore soparated by centrifupatan. The centrifuge had a rotor ridius of $26 \mathrm{~cm}$ and a frequency of $50 \mathrm{~Hz}$. 
พHCे-EP-0,901

This pape intentionglly Left blentk 
WHC.EP.0\%01

\subsection{GAMTM RADHLYSIS OF AQUEOUS ALKALDE BOLUHYNS OF NETTUNIUM}

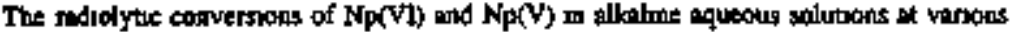

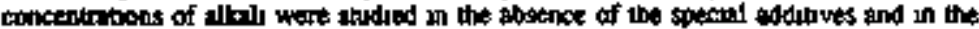
presence of $\mathrm{CO}^{\circ}, \mathrm{NOS}, \mathrm{NO}$, EDTh, and HCOO

\subsection{GAMDA RADOLYS1S OF ALKALDE AQUWOUS SOLUTTONS OF NGPTUNIUM(VD DN TRE ADSENCE OF ADDIMIXS}

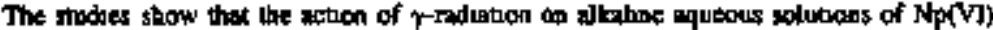

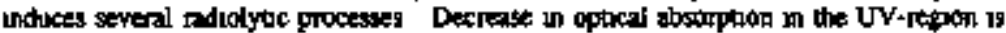
ghuterved at relanvely low doses (wo about 24 KGy) The decrease, consed by the reduction of $\mathrm{Np}$ (VI), ocourred wer the entre stholed range of allall coocentraton (0. 9 to $85 \mathrm{M}$ )

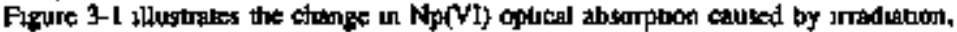

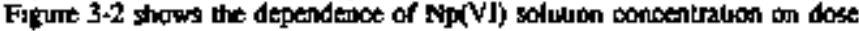

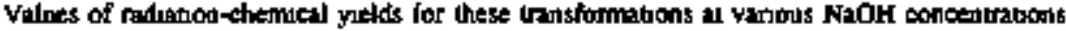

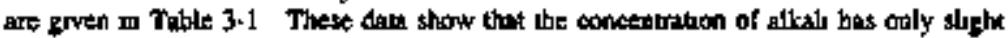

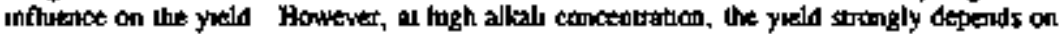

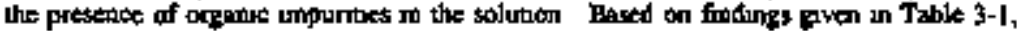

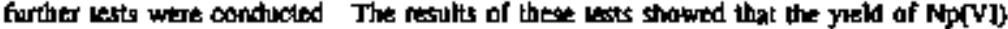

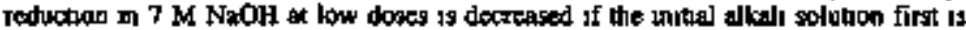

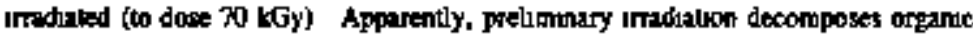

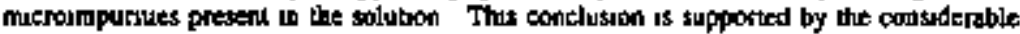
difference in yeid cbserved al relatively low dostes (sec Figure 3.2)

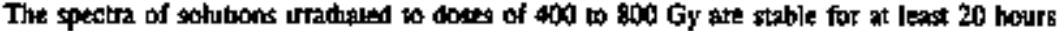

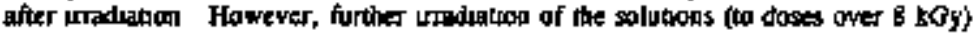
increases the optical sbsoption in the UV and vible regrons Figure 3-3 shows the

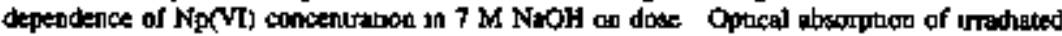
soivtloas also is found bo decreaste whth tme tored oustide the follabon fiedd However, turther urritiauon agan increases optacl absorpton Thus, a type of "oapllalupn" process is observed 


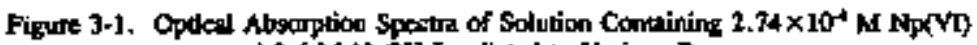
and 3.6 M NoOH Imodtaked to Variours Doses.

Dose, kGy: $1-0 ; 2 \cdot 0.47 ; 3 \cdot 0.94$.

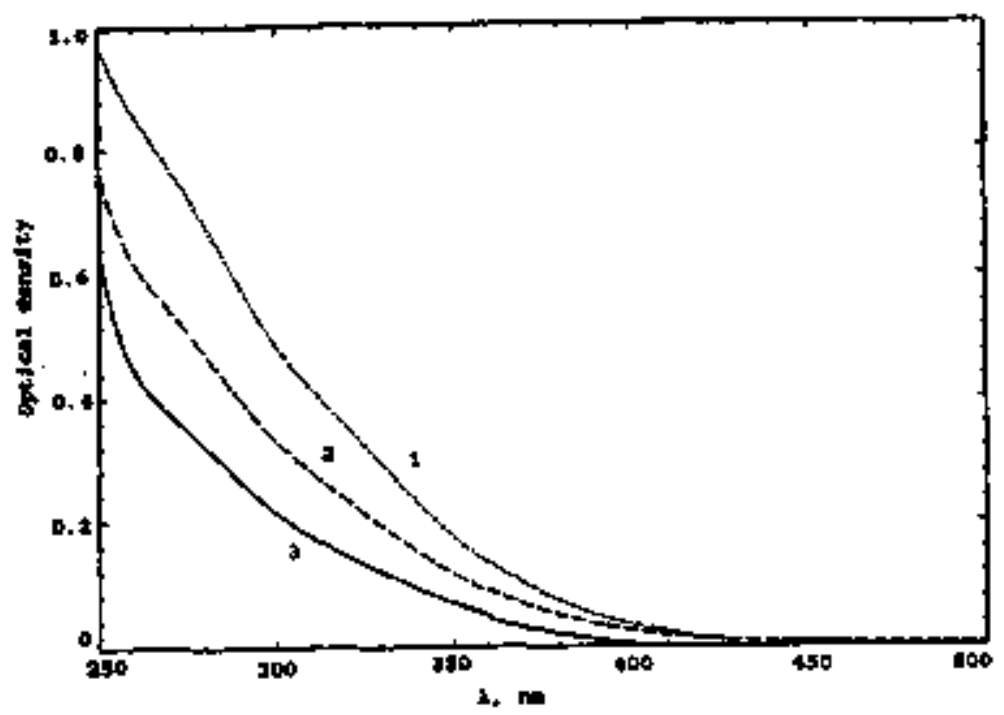


Figure 3-2. Deppeadedece of Np(V) Concentration in $7 \mathrm{M}$ NoOs on Dose.

Alteli solution used for prepsiration of Np(VI) solutions uaderwent preliminary trediation wo dos, kGy: $1=70 ; 2-9$.

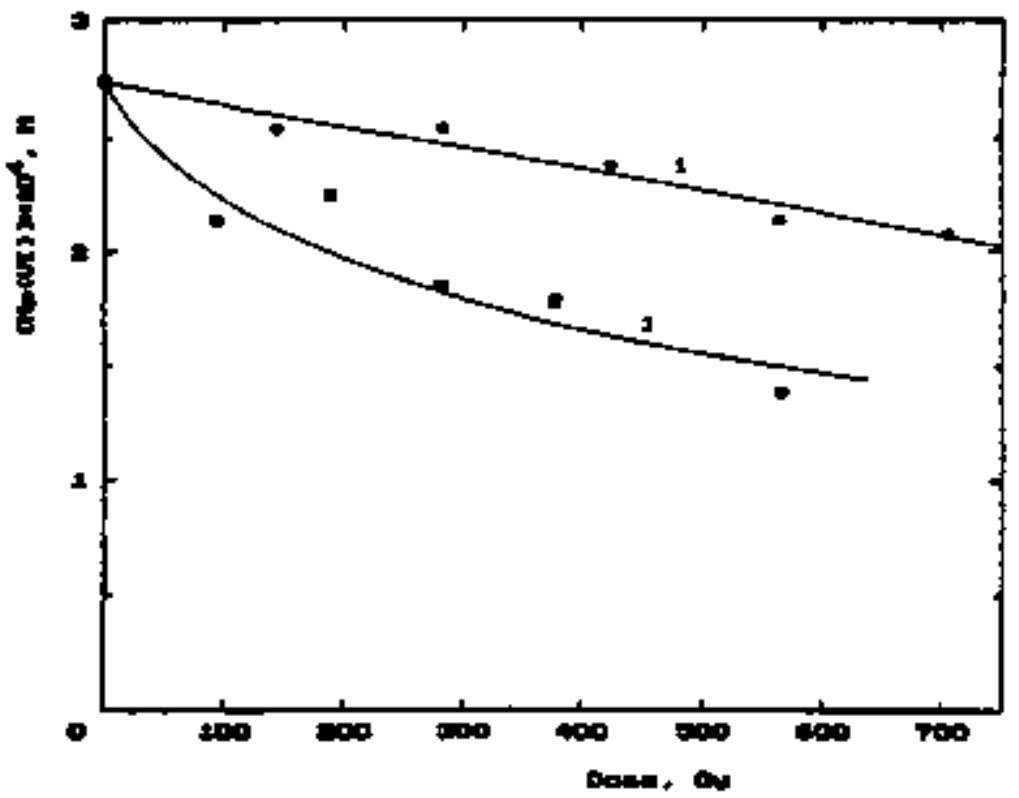




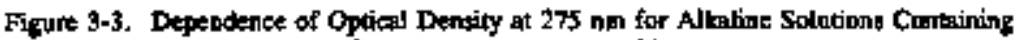
2.7A $\times 10^{-1} \mathrm{M} \mathrm{Np}(\mathrm{VI})$ and $7 \mathrm{M} \mathrm{NaOH}$ on Dast.

The fird 5 poists were obpined al $0.47 \mathrm{kGy}$ h" dose mie; the remaindng points were obtained at 4,3 kGy h'l dasa rato.

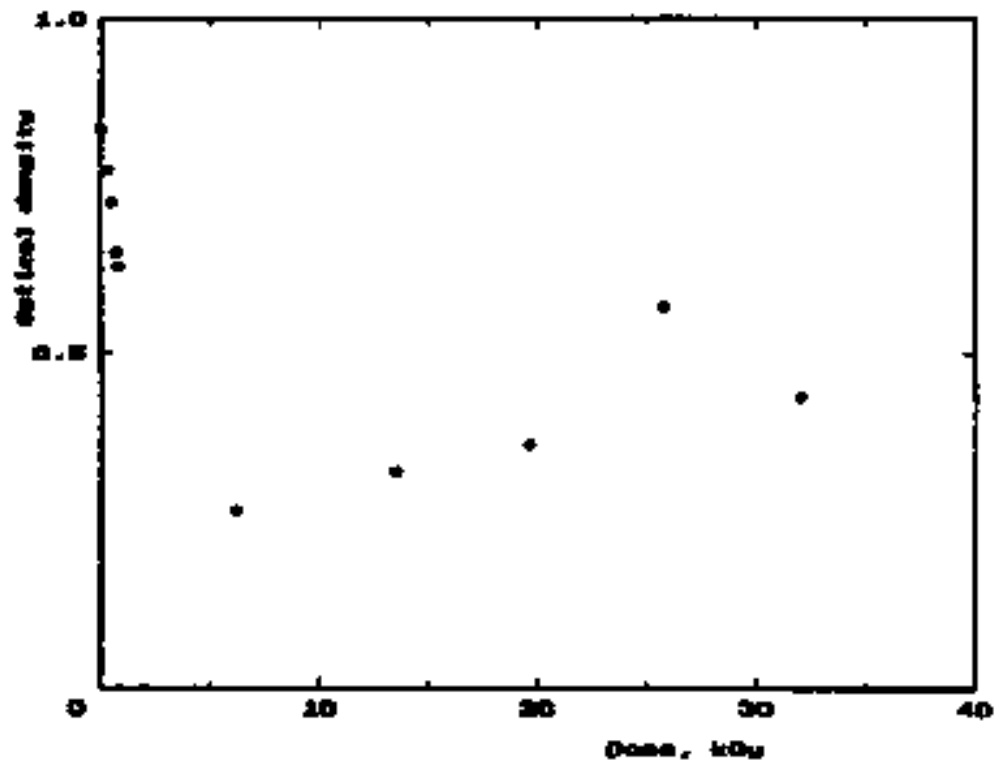


Table 3-1. Rudiption-Chericel Yields of WP(VT) Rectuction, G[-Np(VI)], in Aerived Alkplins Aqueous Solutions.

$[\mathrm{Np}(\mathrm{VT})]=(2.7 * 3.6) \times] \mathrm{O}^{\mathrm{N}} \mathrm{M}$

\begin{tabular}{|c|c|c|c|}
\hline Dethin & Hefilura : & Dovita, Gy & G[- \\
\hline 0.9 & $\cdot$ & 5630 & 1.4 \\
\hline 1.8 & - & 960 & $1.6^{\circ}$ \\
\hline 3.65 & - & $\leq 650$ & 1.4 \\
\hline 7 & $r$ & 5200 & 3.4 \\
\hline 7 & $\cdot$ & $270-650$ & 1.5 \\
\hline$\tau$ & - & $\leq 650$ & 0.7 \\
\hline 2.4 & $C 0^{+}, 0.67 \mathrm{M}$ & 5650 & 0.7 \\
\hline 2 & GDTA, $0.013 \mathrm{~N}$ & 109 & 8.5 \\
\hline 2 & EDTA, 0.013 M & 436 & 3.5 \\
\hline 1.5 & $\mathrm{HCOO}, 0.26 \mathrm{M}$ & 5250 & 5.8 \\
\hline
\end{tabular}

None:

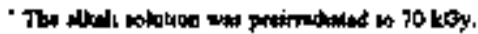

The increged optical absorption occurring a doses over 8 bGy is postulated to result from the formation of Np(V) peroxo complekes. To lest this mypothesis, alkaline NorV) peroso complex solutions wene prepared by adding excess $\mathrm{H}_{2} \mathrm{O}_{1}$ to allolite $\mathrm{NP}(\mathrm{V})$ solntions. The prodact solution spectrum conresponded to that described in Musikas (1974). However, the absurption spectrum caused by the complex decreased and completely disappeared following j-irradiation of the allatine Np(V) peroxa complex solution (see Figure 3-4). Based on these

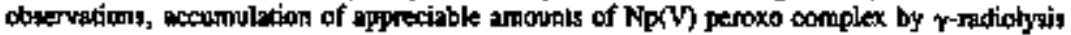
of alkaline soludions of $\mathrm{Np}(\mathrm{V})$ ) and $\mathrm{Np}(\mathrm{V})$ wilhoul additives is improbeble. Wilh $\alpha$-allordiolysis and the attendant hiphet $\mathrm{H}_{2} \mathrm{O}_{2}$ yield, fortmation of peroxo complenes may play a inportand role.

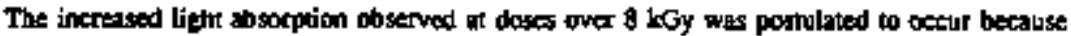
morie or less stable (depending on allati concentration) fine disperse ruspentioss were formed. The following facts corlfirdn this mafgedion. First, a Jyndall cone, enused by bigh sestefing on fine dipporse particles, is observed in such solutions. Second, the intensity of optical absorption depends on the length of time that irredionted solutions ate cenkrifuged. Centrifupation decreased optical shsorption over the entire ohserved spectrum (see Figure 3-5) and a fine settled precipinke accumulated. 


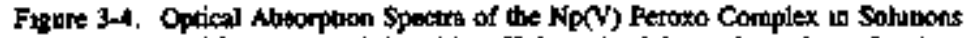
Containung $2.74 \times 10^{-4} \mathrm{M} \mathrm{ND}(\mathrm{V}), 3.9 \times 10^{-4} \mathrm{M} \mathrm{H}_{2} \mathrm{O}_{2}$ and $4.2 \mathrm{M} \mathrm{NaOH}$ After r-Imadiatloo.

Dose, k0y: 1 - 0;2 - 2.15; 3 - 43; 4, 3 - 645;6 - 12.9.

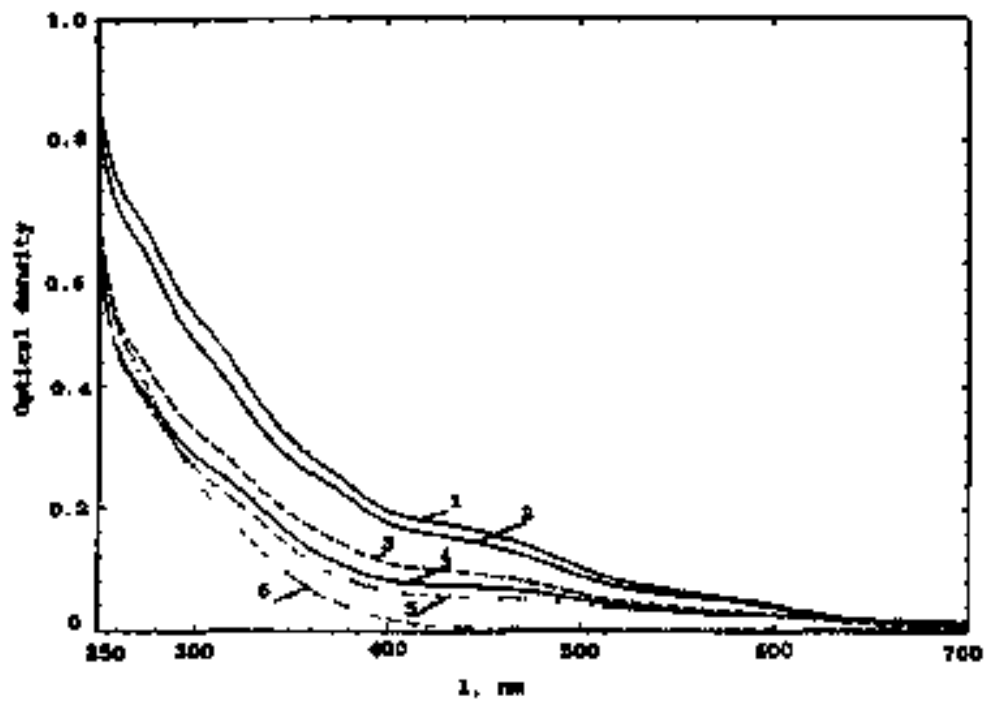


Flgure 3-5. Optical Atoorption Spectre of $2.74 \times 10^{-4} \mathrm{M} \mathrm{Np(VT)}$ and $7 \mathrm{M} \mathrm{NaOA}$.

Dow, kGy: 1 - 0; 2 - 25; 3 - 25 afler 3 Minumes' Centrifuration; 4- 25 after 13 Minukes' Additionss Centrifugallon.

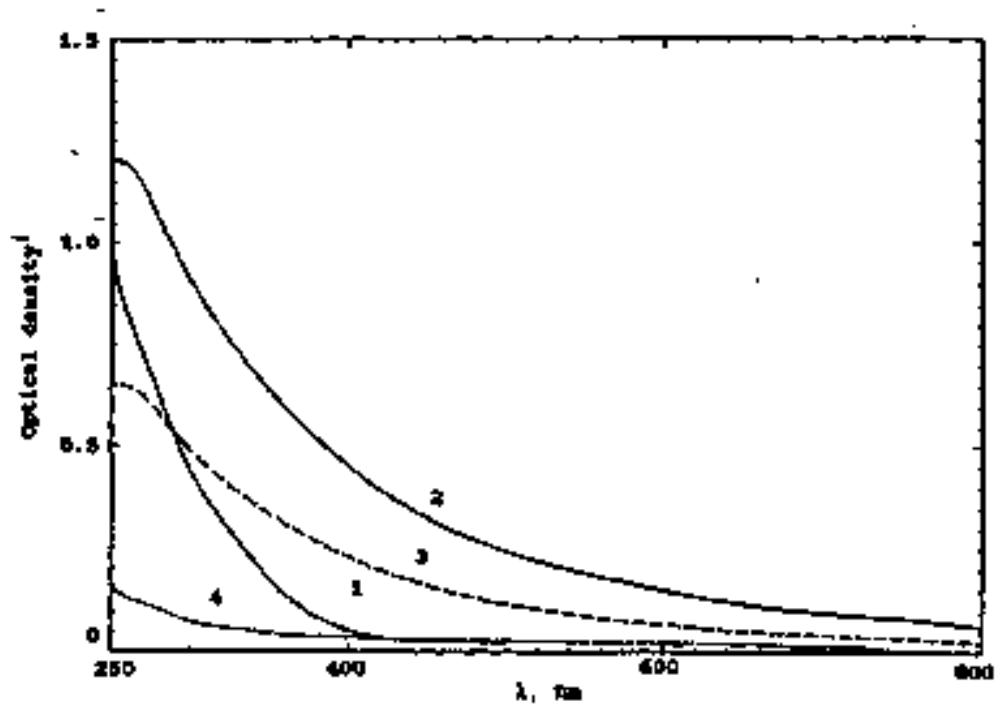




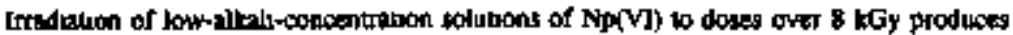

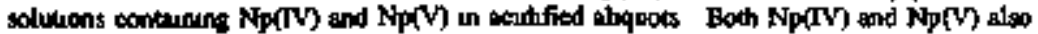

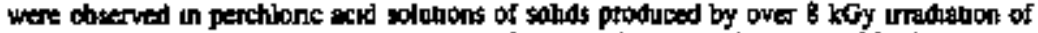

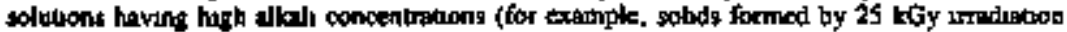

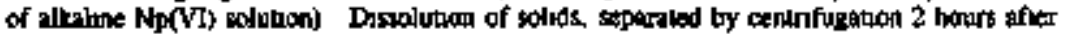

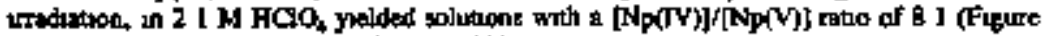
3-6) Sigauficandy, no Np(VI) $\lambda_{-}$at $1223 \mathrm{~nm}$ ) was observed by spectrophotometry

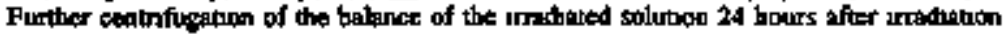
x-porated a preciptale whoch, after dissolubon in 21 M HCH., hed a [Np(TV)]/[Np(V)] ratao of 231 (see Figure 3-7) The kower ralo is explataed by the oxidation of NP(IV) by gtmosphenc oxygen followng worage of the urrachaled solution Oxidation of Np(TV)

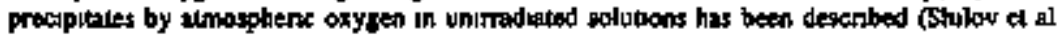
1996)

In summury, Np(TV) procipalates form in solutumb irtaliated to over 8 kGy dose, these

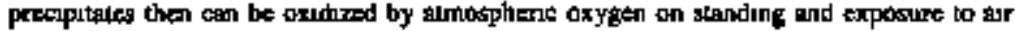

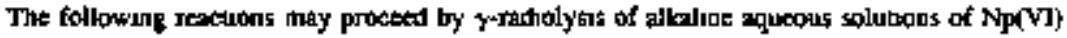

$$
\begin{aligned}
& \mathrm{H}_{2} \mathrm{O} \sim \mathrm{C}_{\mathrm{cq}} \mathrm{H}_{1} \text { OH, } \mathrm{H}_{2} \mathrm{O}_{2}, \mathrm{H}_{3}, \mathrm{H}^{*} \text {, OH } \\
& \mathrm{H}+\mathrm{OH} \rightleftharpoons \mathrm{E}_{3}+\mathrm{H}_{7} \mathrm{O} \\
& \mathrm{OH}+\mathrm{OH}=\mathrm{O}+\mathrm{H}_{2} \mathrm{O} \\
& \mathrm{H}_{2} \mathrm{O}_{2}+\mathrm{OH} \rightleftharpoons \mathrm{HO}_{3}+\mathrm{H}_{2} \mathrm{O} \\
& \mathrm{H}+\mathrm{O}_{3}+\mathrm{HO}_{3} \\
& c_{14}+a_{2} \rightarrow a_{2} \\
& \mathrm{HO}+\mathrm{OH} \rightarrow \mathrm{O}_{3}+\mathrm{H}_{7} \mathrm{O} \\
& e_{m}+\mathrm{Np}(\mathrm{VI})-\mathrm{Np}(\mathrm{V}) \\
& \mathrm{e}_{m}+\mathrm{Np}(\mathrm{V})+\mathrm{Np}(\mathrm{IV}) \\
& \mathrm{HO}_{2}+\mathrm{Np}(\mathrm{Vl}) \rightarrow \mathrm{Np}(\mathrm{V})+\mathrm{HO}_{3} \\
& \mathrm{O}_{2}+\mathrm{Np}(\mathrm{Vl}) \rightarrow \mathrm{Np}(\mathrm{V})+\mathrm{O}_{2} \\
& H O_{2}+N p(I V)+N p(V)+O+O H
\end{aligned}
$$


Figure 3-6. Optial Absomption Spectrum of the Solution Paepanted by Dissolution, in $2.1 \mathrm{M}$ KClO., of Precipitates Obained by Centrifugation Twn Hours Afles Irstiation of $2,74 \times 10^{+} \mathrm{M} \mathrm{Np}(\mathrm{VI})$ and $7 \mathrm{M} \mathrm{MaOH}$ o $25 \mathrm{kGy}$.

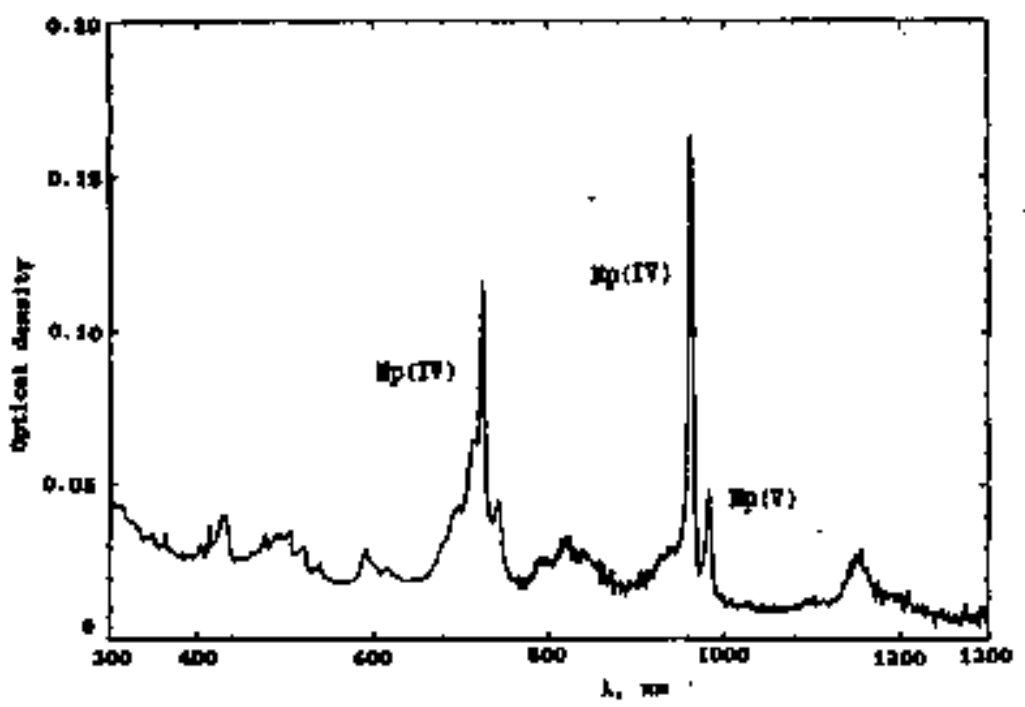


Figute 3-7. Optical Absorption Spectivm of the Solvtion Pripared by Disbolution, In $2.1 \mathrm{M} \mathrm{HC1O}$, of Precipitres Obuined by Centrifogation 24 Hours After Lradiation of $2.74 \times 10^{-4} \mathrm{M} \mathrm{Np}(\mathrm{VI})$ and $7 \mathrm{M}$ NaOH $225 \mathrm{kGy}$.

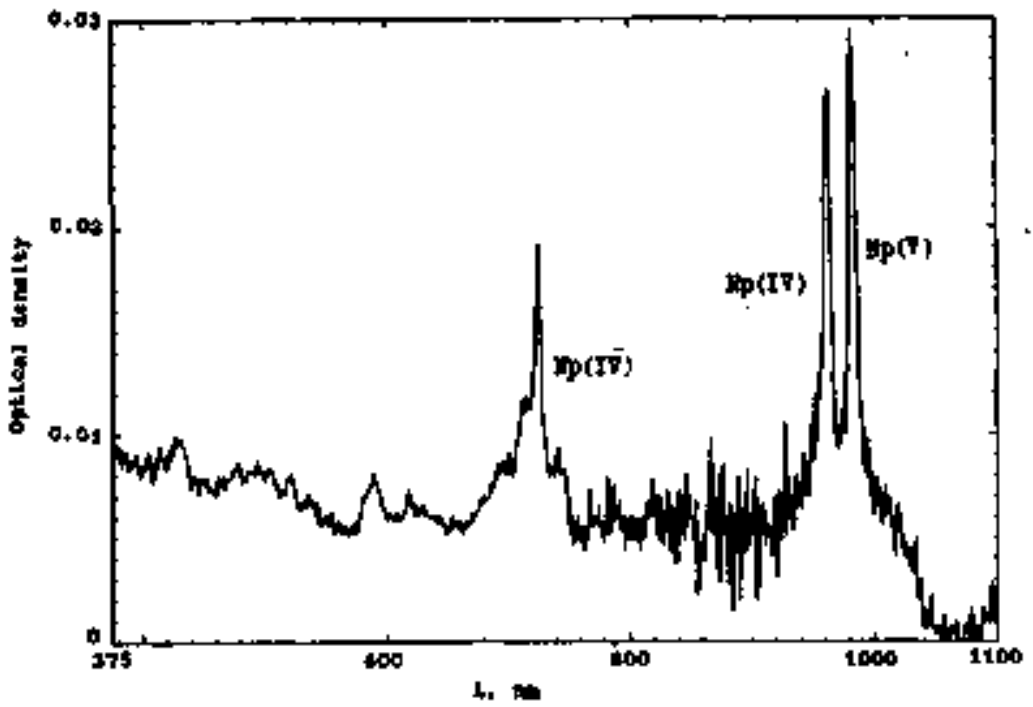




$$
\begin{aligned}
& \mathrm{O}_{1}+\mathrm{Np}(\mathrm{TV})+\mathrm{Np}(\mathrm{V})+\mathrm{O}_{2} \\
& \mathrm{~Np}(\mathrm{~V})+\mathrm{O}^{+}+\mathrm{H}_{2} \mathrm{O} \rightarrow \mathrm{Np}(\mathrm{VI})+2 \mathrm{OH}^{-} \\
& \mathrm{O}^{+}+\mathrm{HO}_{\mathrm{S}} \rightarrow \mathrm{OH}^{*}+\mathrm{O}_{\mathrm{s}} \\
& \mathrm{C}_{4}^{+}+\mathrm{HO}_{7} \rightarrow \mathrm{OH}^{-}+\mathrm{O}^{-} \\
& \mathrm{Np}(\mathrm{TV})+\mathrm{Np}(\mathrm{VI}) \rightarrow 2 \mathrm{~Np}(\mathrm{~V}) \\
& \mathrm{O}_{2}+\mathrm{HO}_{2} \rightarrow \mathrm{O}_{2}+\mathrm{HO}_{2} \\
& \theta^{r}+\phi_{2}+\phi_{5} \\
& \mathrm{NP}(\mathrm{IV})+\mathrm{O}^{-}+\mathrm{H}_{2} \mathrm{O}+\mathrm{Np}(\mathrm{N})+\mathbf{2} \mathrm{OH} \\
& \mathrm{Np}(\mathrm{TV})+\mathrm{O}_{j}+\mathrm{H}_{\mathrm{p}} \mathrm{O} \rightarrow \mathrm{Np}(\mathrm{V})+\mathrm{O}_{2}+2 \mathrm{OH}^{-} \\
& \mathrm{NP}(\mathrm{V})+\mathrm{O}_{j}+\mathrm{H}_{2} \mathrm{O} \rightarrow \mathrm{Np}(\mathrm{VT})+\mathrm{O}_{7}+2 \mathrm{OH}^{-} \\
& \mathrm{NpN}\left(\mathrm{O}_{3}+\mathrm{O}_{2}^{-}+\mathrm{H}_{2} \mathrm{O} \rightarrow \mathrm{Np}(\mathrm{Nll})+\mathrm{O}_{2}+2 \mathrm{OH}^{*}\right. \\
& \mathrm{O}_{2}+\mathrm{Np}(\mathrm{VII}) \rightarrow \mathrm{O}_{2}+\mathrm{Np}(\mathrm{VI}) \\
& \mathrm{HO}_{2}+\mathrm{Np}(\mathrm{VD})-\mathrm{HO}_{2}+\mathrm{Np}(\mathrm{VI}) \\
& N_{p}(V)+N_{p}(V)+N_{p}(V)+N_{p}(V t) \\
& N p(V)+N p(V T)-2 N p(V) \\
& \mathrm{Np}(\mathrm{VI})+\mathrm{O}+\mathrm{H}_{2} \mathrm{O} \rightarrow \mathrm{Np}(\mathrm{VI})+2 \mathrm{OH}^{\circ}
\end{aligned}
$$

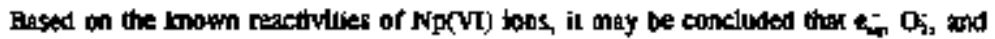
hydrogen peroxdde reduce Hp(VI) ioos (Piloev et al. 1993, Peretruithin el il. 1995, and Gopolev et al 1996). Note that $k_{10}$ and $k_{11}$, the rake constanis of Reactions 10 and II, respectively, dpcrase with increassing alkali concentration. In I M LiOH, they sre 140 and

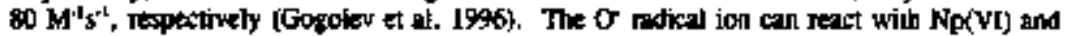

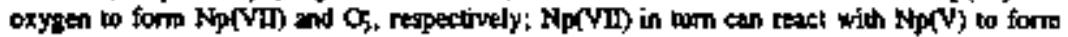

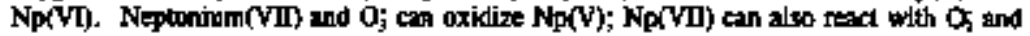

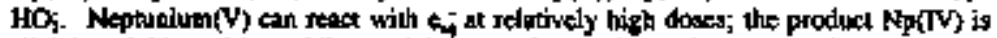
slighuly solnble and ts mopidly procipitaied to form a finely disperied solid phase. Because the oxddexion of Np(IV) th the solit phate is relatively glow, NP(TV) solid phage nocumulates a high dose on $\gamma$-ridiolysis of alloline aquecous NP(VI) solutions. 
Al bow dosea, Np(V) it rodoced to Np(N) by Rtechons 8, 10, and II In Reactrons 23 and

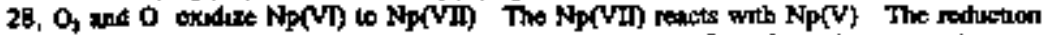
of Np(V) a Np(IV) w not observed under these condibons Therefore, the value of Gi Np(V1)! at low doses is descrabed by the following equation

$$
\mathrm{G}[-\mathrm{Np}(\mathrm{V}] \mathrm{)}]=\mathrm{G}_{\mathrm{C}}+\mathrm{G}_{\mathrm{H}}+2 \mathrm{G}_{\mathrm{BO} \mathrm{r}}-\mathrm{G}_{\mathrm{OH}}
$$

where $G$ values on the nom are untal yrelds of pnmary products of waker radiolyss

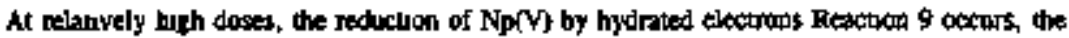
relevini equation for G[-Np(V)] i*

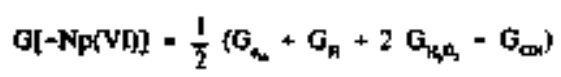

For alloline solutions at pH 12 w 13 , the individual inttal yedds are known $G, 0305$,

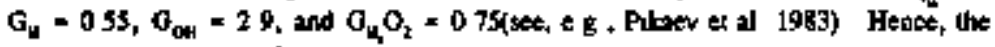
G[-Np(VT)], calculaited from Equagong 29 and 30 for solutions wilb abovl $1 \mathrm{M}$ alkall show]d be 22 and I I ron/100 eV, reipectrvely Howeves, expenmental values for ewen bow doest, shown in Table 3-5, are lower than 22 ion'l00 eV This shortiafl can be explained by the

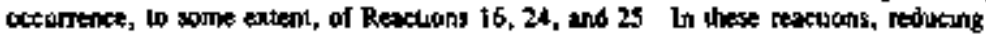
specess are consumited

Bexpuse the G vilnes for the primary products of ridiolysis in concentraled aqueculs alkali

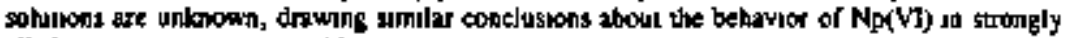
alkine systems is gol posuble

Hydtogen peroude can be expected to actumulak by radolyses If so, the Np(V) peraxo complex moudd be poshlaled al relauvely high doses when most of the $\mathrm{K}_{\mathrm{p}}$ (VI) is neduced However, perono complexes pre pol observed This likely is because hydrogen peroxide

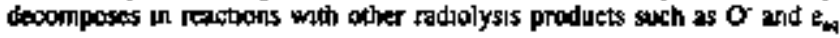

\subsection{GAMMA RADNOLYSTS OF ALKALINE AQUDOUS SOLUTIONS OF NEPTUNIIUM(Y) IN THE PRESENCE OF ADDITVES}

The effects of cabonak, onganc compounds, utuate, and nithte on pamma radklysis of neplumum(VT) were investigatod

\subsubsection{Cortonate}

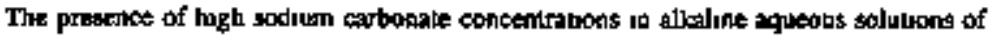
Np(V]) was a redavely small effect on r-rediolysis Fugure 3-8 shows the decreace in 


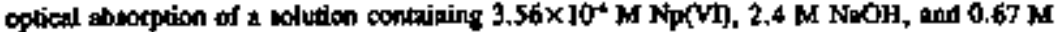

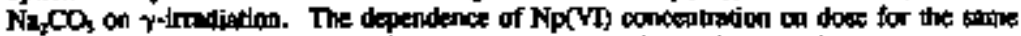
solntion is presented in Figure 3-9. The G[-NP(VT)] value, elikulated from the data pratentad in Figures 3-8 and 3-9, is given in Table 3.1 ond can be oxmpared with the G[Np[Vt)] values found in alkalase soluticn wilsout carbonose.

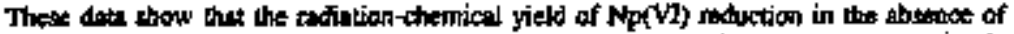
cartonale bo companble with, bux someshat bigher than, that found in the mesarit of carbontte. These resalts indicate lant the radieal ion $\mathrm{CO}$ formed in reactions of carbonate

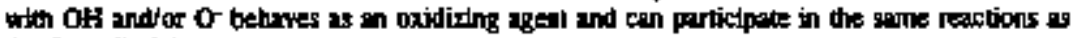
the $\sigma$ radicel tor.

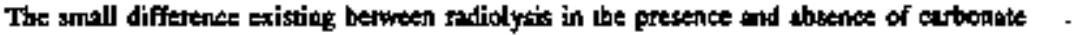
might be explatined by the influence of organic impuntles. However, $\mathrm{CO}_{3}$ only reacts stowly will organic compounds to form oromic free naticals. Therefore, the reduction of NP(VT) by organic free radlcals is improbsble. This deduction is centfimed by the fact that the influenes of organic impurities in eatonate-alkaline solutions is not as signdfieant as it is th dlkatint modia. 
Figure 3-8. Optictot Absorption Spectrs of

$3.56 \times 10^{-} \mathrm{N} \mathrm{Np}(\mathrm{VT}), 0.67 \mathrm{M} \mathrm{N}_{2} \mathrm{CO}_{3}$, and $2.4 \mathrm{M} \mathrm{NaOH}$ as a Funchon of Dose.

Dase, LGy: $1 \cdot 0 ; 2-0.45 ; 3-0.97,4-1.3 ; 5-2$

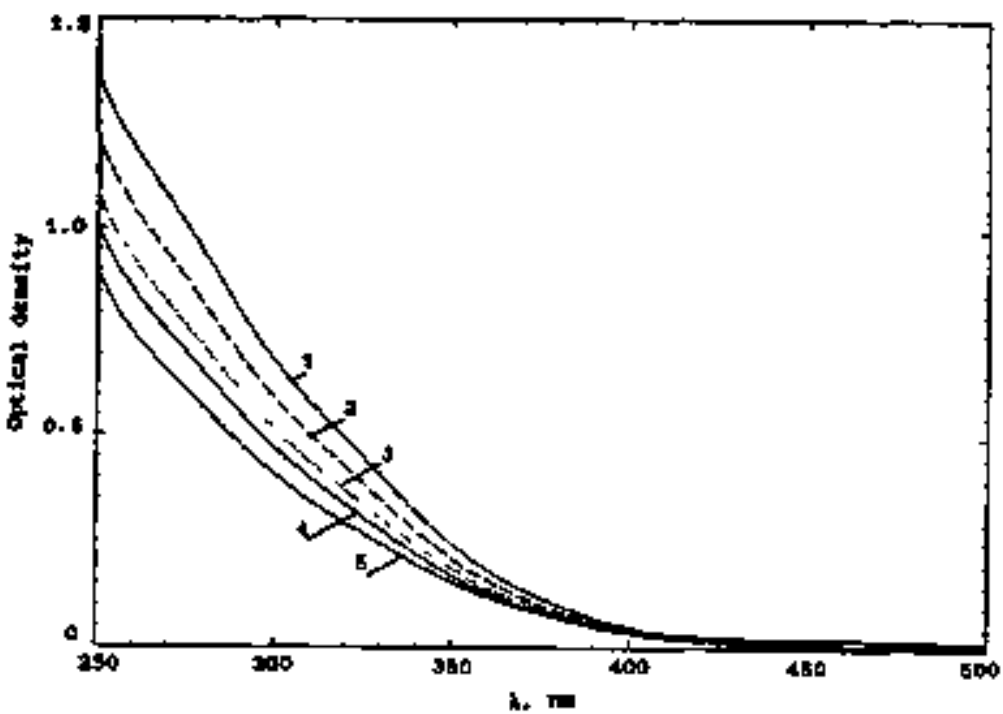


Figure 3-9. Dependence of Np(VT) Coscontration on Dose is $0.67 \mathrm{M} \mathrm{Na}, \mathrm{CO}_{1}$ and $2.4 \mathrm{~N} \mathrm{NaOH}$.

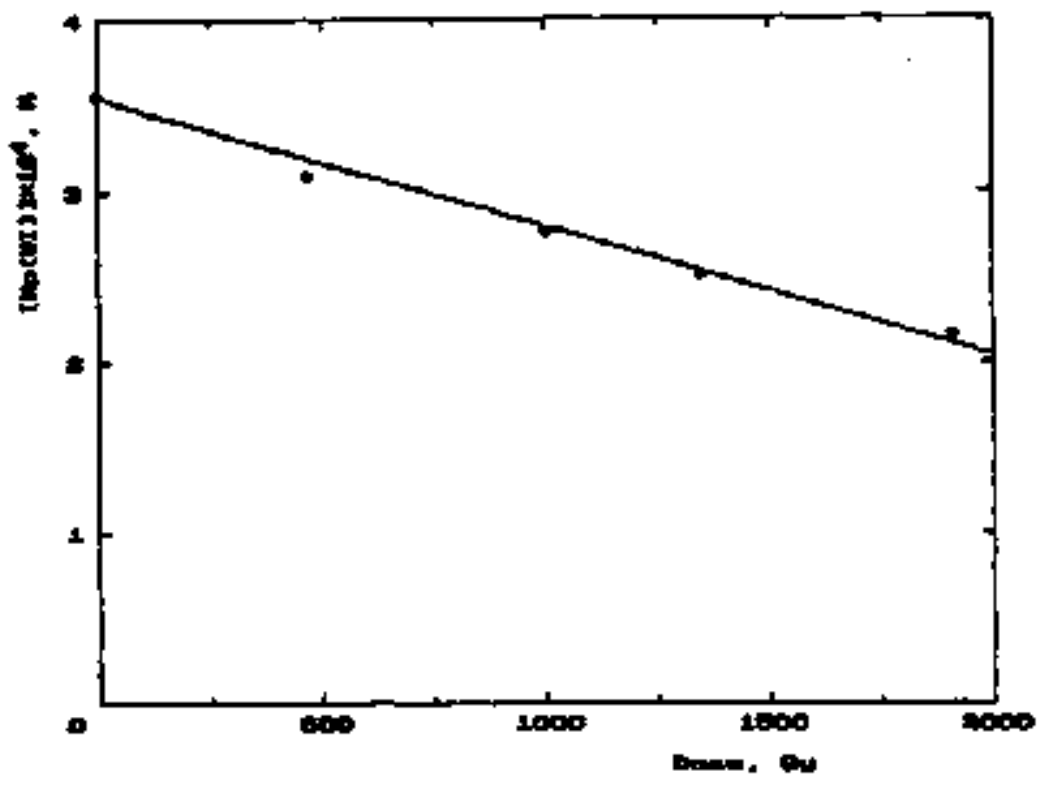




\subsubsection{Oreanc Cemponds}

In peneral, orgare componmts seavenge OH (and O') radicals The products of the

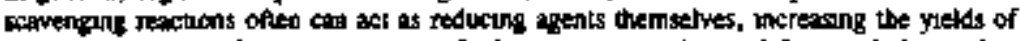

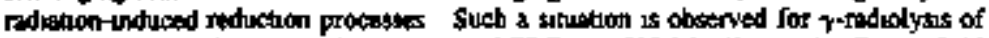

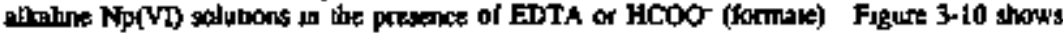

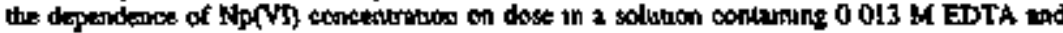
$2 \mathrm{M} \mathrm{KaOH}$

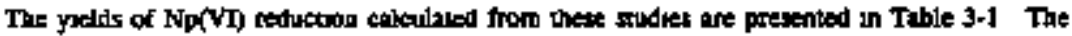
data show tha grelds in the presence of EDTA or HCOO are much hipher then in ther: abeace The folkowisg example, for sortarte, explans the observactong First, the hydroxy] radrcal reactung with $\mathrm{KCOO}-$

$$
\mathrm{HCOO}+\mathrm{OH}(\mathrm{O})+\mathrm{COO}^{-}+\mathrm{H}_{1} \mathrm{O}(\mathrm{OH})
$$

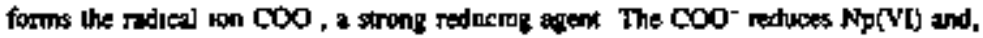
posstily, $\mathrm{Np}(V)$ by the followmi resctions

$$
\begin{aligned}
& \mathrm{Np}(\mathrm{VI})+\mathrm{COO}+\mathrm{Np}(\mathrm{V})+\mathrm{CO}_{2} \\
& \mathrm{~Np}(\mathrm{~V})+\mathrm{COO}-\mathrm{Np}(\mathrm{NV})+\mathrm{CO}_{1}
\end{aligned}
$$

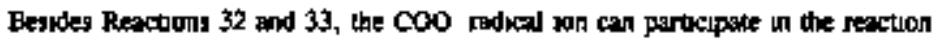

$$
\mathrm{COO}+\mathrm{O}_{2} \rightarrow \mathrm{CO}_{2}+\mathrm{O}_{1}
$$

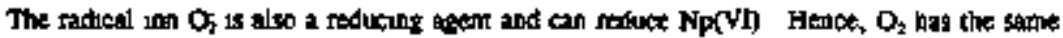

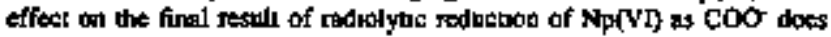

The urechangsm of Np(V) redurctan on solutions contanning EDTA is almosi the same The

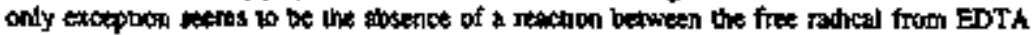
and orygen to form os

At sufficiently low doses, reduction of NP(VT) proceeds only to NP(V) The yeld may be expessed by the aquation

$$
\mathrm{G}[\mathrm{Np}(\mathrm{V})]=\mathrm{G}_{\mathrm{L}}+\mathrm{G}_{\mathrm{H}}+\mathrm{G}_{\mathrm{GH}_{\mathrm{H}}}+2 \mathrm{G}_{\mathrm{H}, \mathrm{L}}
$$

Based on these known $G$ values, the yreld for $1 \mathrm{M} \mathrm{NaOH}$ thould be 8 wn' $100 \mathrm{eV}$ 
Fipure 3-10. Dependence of Np(V]) Concentration on Dose in $0.013 \mathrm{M}$ EDTA and $2 \mathrm{M} \mathrm{NaOH}$.

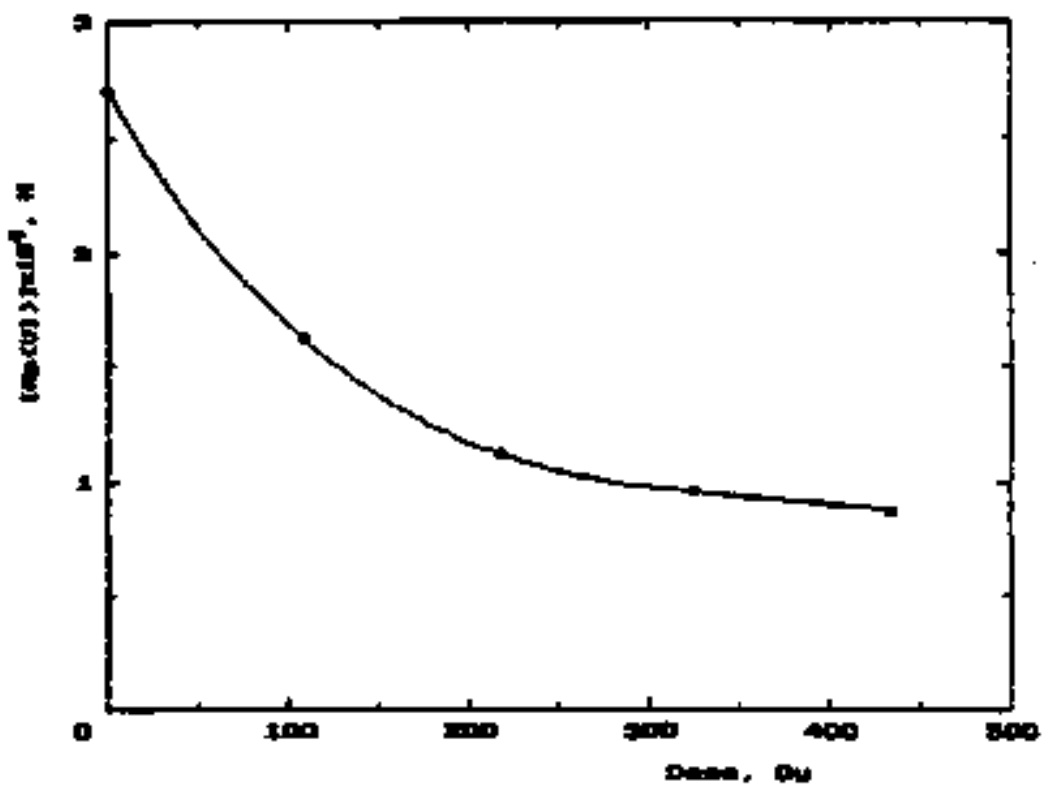


In the cast of reduction to Np(TV), the corregrondang equation is

$$
G[-N p(V T)]=\frac{1}{7}\left(O_{4}+O_{1}+G_{0+1}+2 O_{u, a}\right)
$$

and the ynatd aluould be 4 sod $100 \mathrm{eV}$

The axpenenental yuld for the solution convalue EDTA st low dose is close wo that

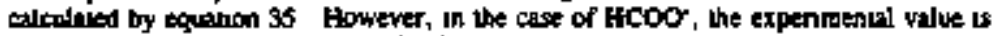
notresably lower The low value for formite cerd be explanned in the same way as for the ratucikn of Np(Y) in the absence of additives, 1 e , Reachons 16, 24, and 25 also occur and can consume reducing ipecies

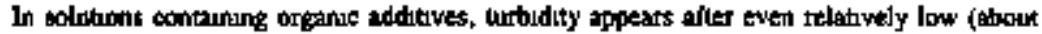

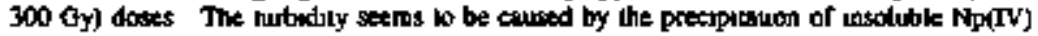

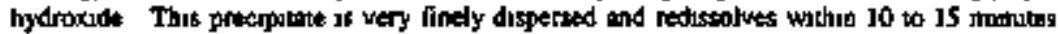
after irtadution withoul suming The redissolution is caused by the oxitauton of ine ND(TV)

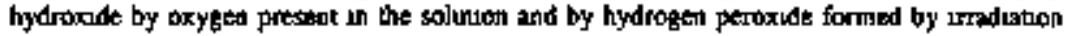

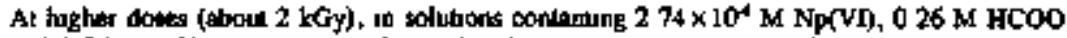

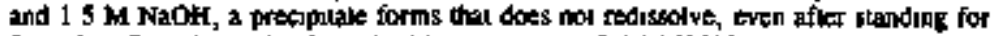

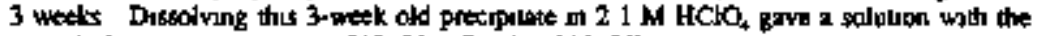

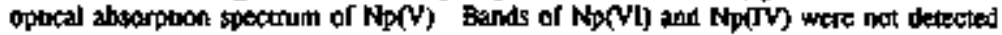
Apparanty, on storage of meb solutrons, Np(TV) is oxudzed by amasphene oxygen to the more soluble $\mathrm{Np}(\mathrm{V})$

\subsubsection{Nltrite and Karate}

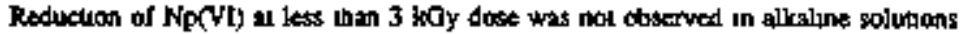

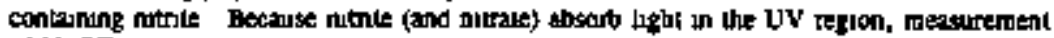
of Np(V) exneentertion changes cannot be monatored through the Np(VI) chatge-trimsfer

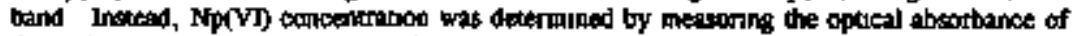

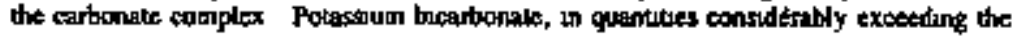

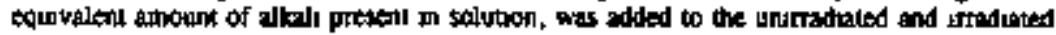

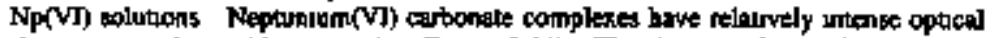

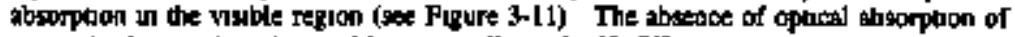

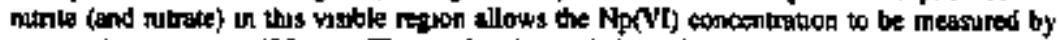
pectrophotometry at $425 \mathrm{~mm}$. The results obtanned showed that both the unuradiaked and

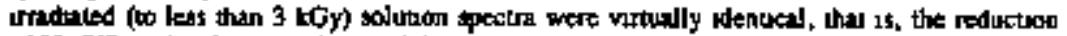
of Np(VD) under these condhbors did not occur

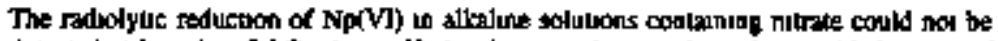
delected at lest than 2 kGy doese Under these conditions, the reduction lwely proceeds osily 


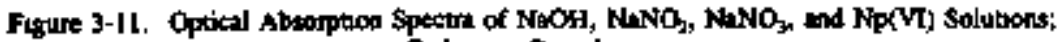
Carbonale Couplezes.

1 - $2 \mathrm{M} \mathrm{KNO}$, and $0.9 \mathrm{M} \mathrm{NaOH;}$

2 - $0.11 \mathrm{M}$ NaNO, and $0.81 \mathrm{M} \mathrm{NaOH;}$

3 - $2.74 \times 10^{*} \mathrm{M} \mathrm{Na}(\mathrm{VT}) \mathrm{Np}(\mathrm{V})$ and $2.6 \mathrm{M} \mathrm{NaOH}$;

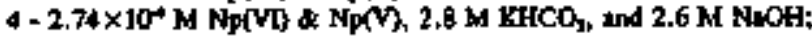

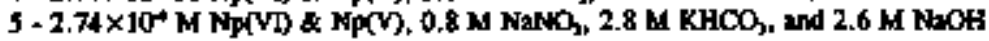
uraduated to 1 KGy

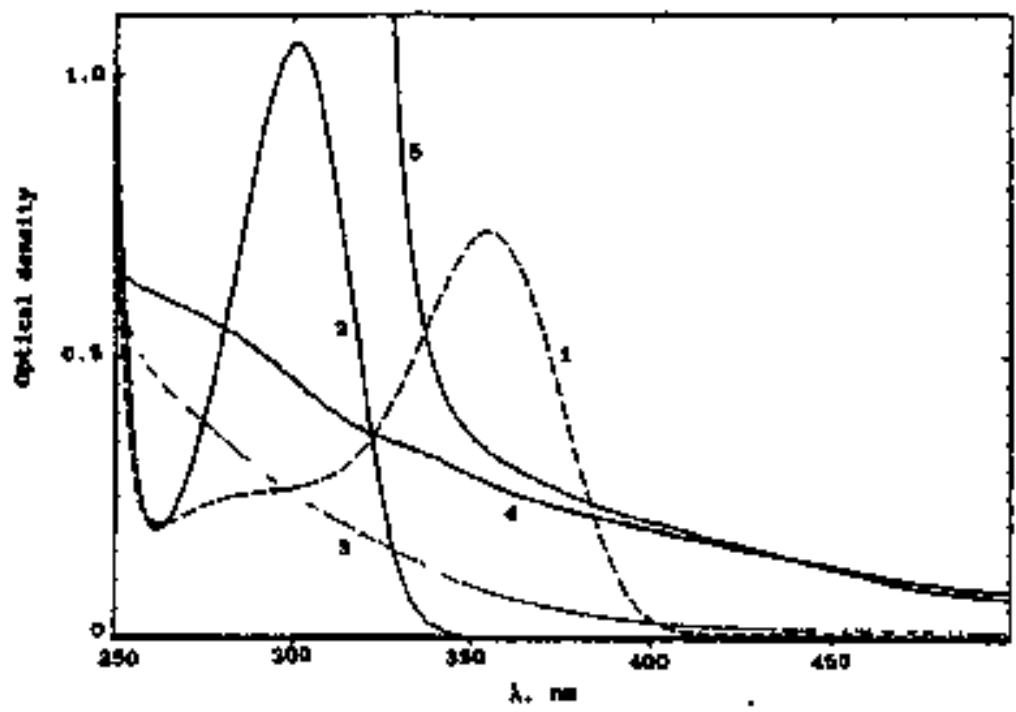


Wh compantavely kow yneld Howtwer, the mechod ustd to andyre Np(VT) is not

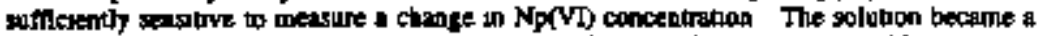

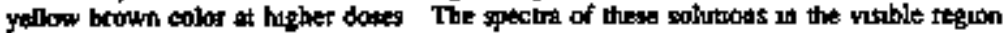

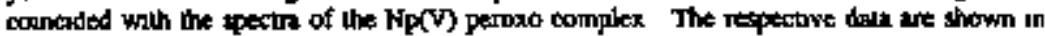

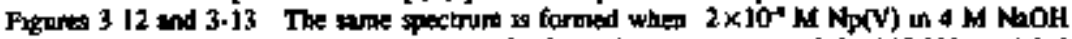

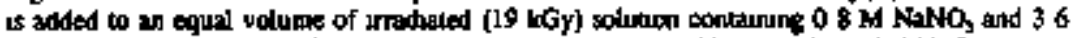

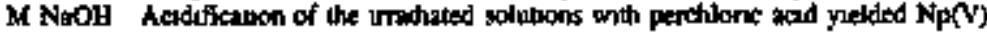
solutiogs Adding EDTh or pumte to the soluton conlmung the NP(V) peroxp complex had

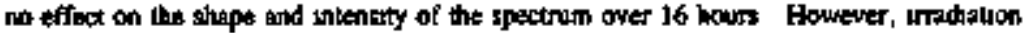

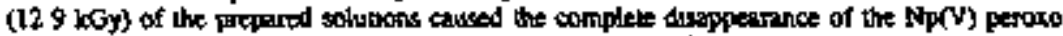
complax Thete effects are allustrabed by Figures 3-14 and 3 IS

The obuerved tesulu tory be explaned qualiatively as follows Firs, the hydrated electron reaces readly with $\mathrm{NO}_{3}$

$$
\mathrm{C}_{\mathrm{m}}+\mathrm{NO}_{1} \rightarrow \mathrm{NO}_{3}^{2}
$$

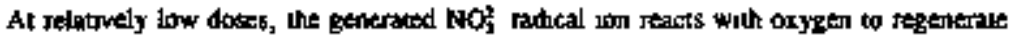
mitralle

$$
\mathrm{O}_{3}+\mathrm{NO}_{\mathrm{Z}} \rightarrow \mathrm{O}_{3}+\mathrm{NO}
$$

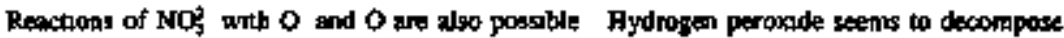

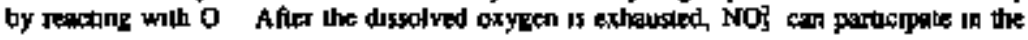
reoction

$$
\mathrm{Np}(\mathrm{VT})+\mathrm{NO}_{2}^{*} \rightarrow \mathrm{Np}(\mathrm{V})+\mathrm{NO}
$$

and the peoduct Np(V) ean react whth hydrogen peroxide to focm the peroxo complex

In solutions contuning nitnte, the hydrated electron partacapies in the reachon

$$
\mathrm{H}_{4}+\mathrm{NO} \rightarrow \mathrm{NO}_{2}^{\mathrm{x}}
$$

The 0 rodkell kon also feracts with antme

$$
\mathrm{O}+\mathrm{NO}+\mathrm{H}_{2} \mathrm{O} \rightarrow \mathrm{NO}_{2}+2 \mathrm{OH}
$$

Apparealy, hydrocen peroxde an be decomposed by rectuons wilh spectes formed in Reactions 40 and 41 
Figure 3-12 Optacal absocptacon Spectra of $\mathrm{NaOH}, \mathrm{NaNO}_{2}, \mathrm{NaNO}_{3}$ and $\mathrm{Np}$ (VI) Soluloons, Formstion of Perosio Complexes

1 - $274 \times 10^{-1} \mathrm{M} N \mathrm{~Np}(\mathrm{VI})$ and $69 \mathrm{M}$ NaOH, unurrathated.

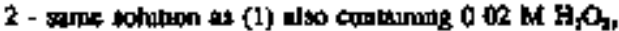

3 - $274 \times 10^{-4} \mathrm{MP}(\mathrm{V})$ and $5 \mathrm{M}$ NaOH, ummedated.

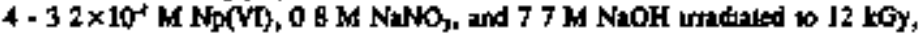

5 - $32 \times 10^{4} \mathrm{M} \mathrm{Np}(\mathrm{VI}) .12 \mathrm{M} \mathrm{NaNO}$, and $77 \mathrm{M} \mathrm{NhOH}$ irradtaled $612 \mathrm{kGy}$

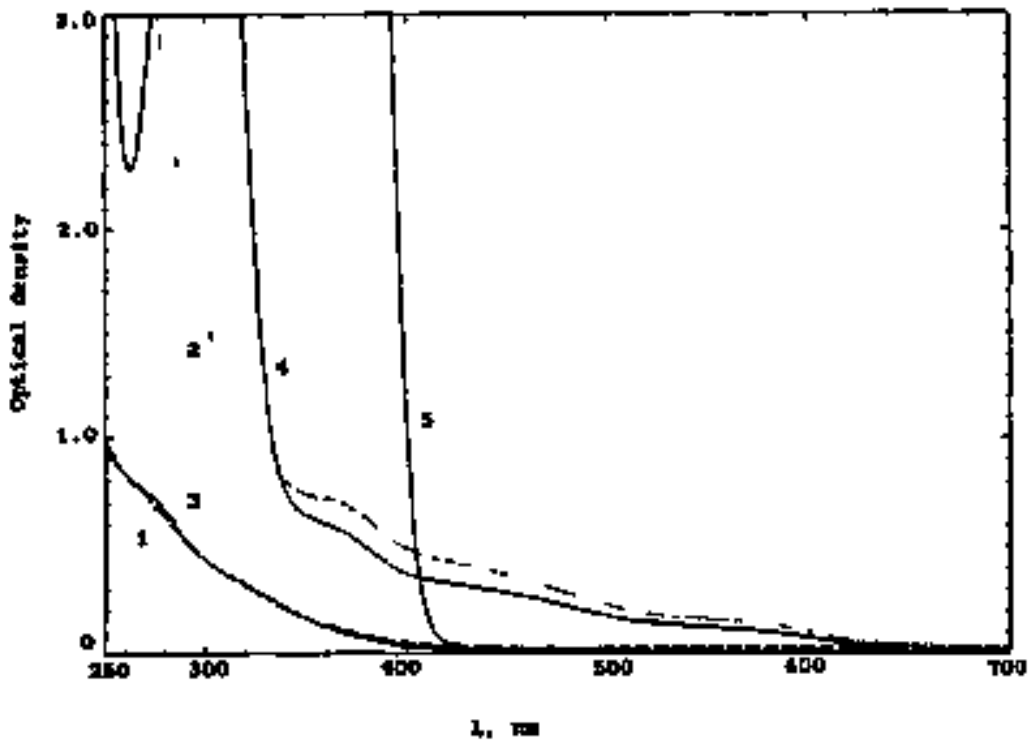


Figure 3-13. Optical Alsorption Spectre of KhOF axt Np(VI) Soluthons.

1 - $2.74 \times 10+\mathrm{M} \mathrm{Np}(\mathrm{VI})$ and $8.5 \mathrm{M} \mathrm{NaOH}$, unimsdinted;

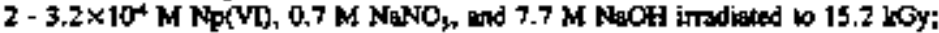

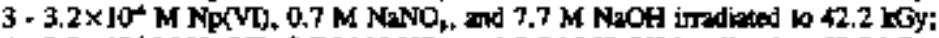

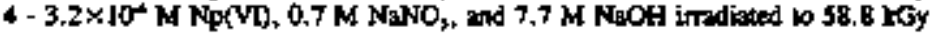

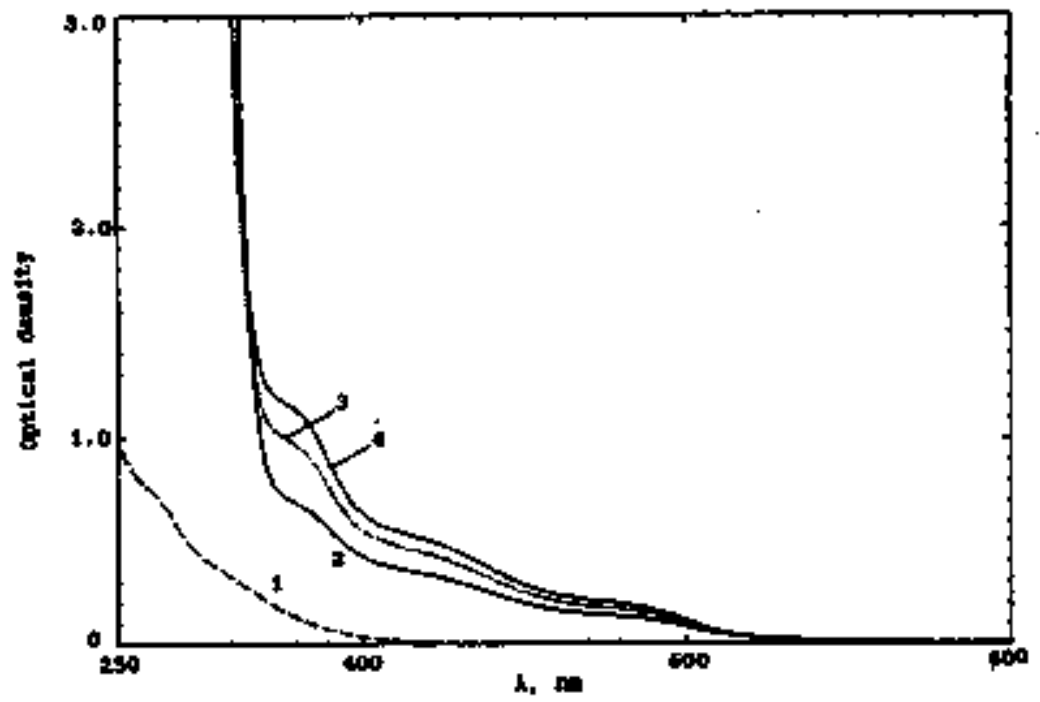


Figure 3-14. Opdcal Abouptlon Spertra of N3OH, NaNO, and Np(VT) Solutions with Adrat Nitrik.

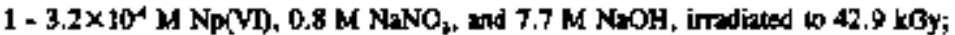

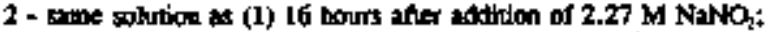

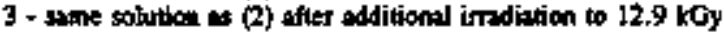

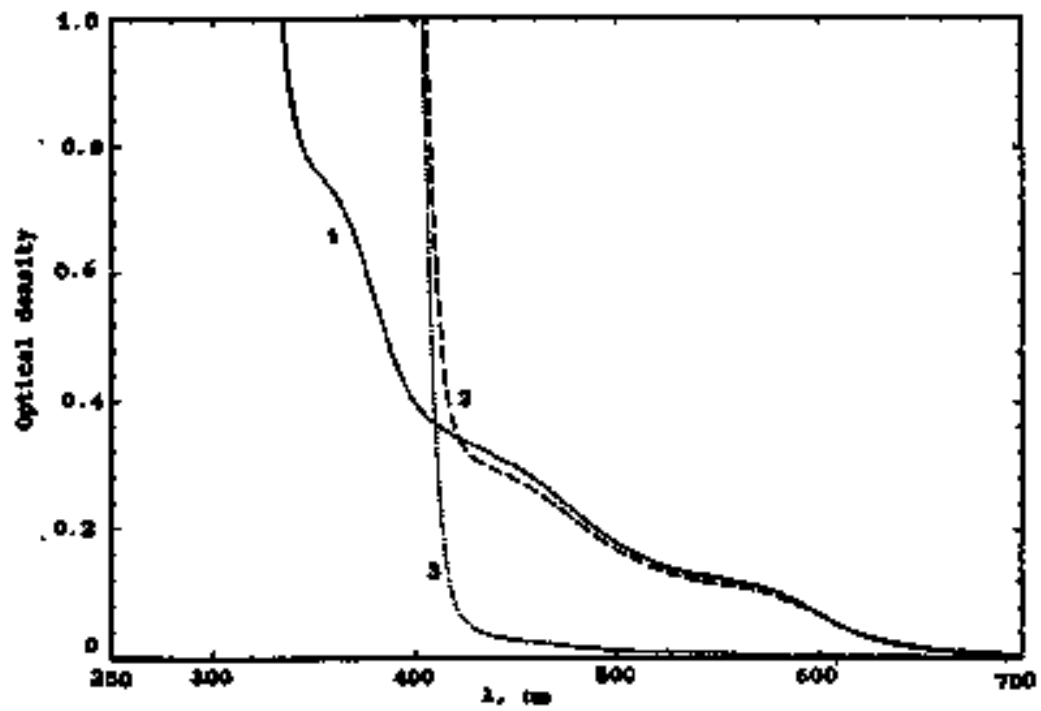




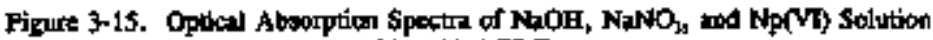
with Added EDTA.

1 - $3.2 \times 10^{-1} \mathrm{M} \mathrm{Np}(\mathrm{VI}), 0.8 \mathrm{M} \mathrm{NaNO}$, and $7.7 \mathrm{M} \mathrm{NaOH}$ irmatiand to $55.8 \mathrm{lOCy}$ :

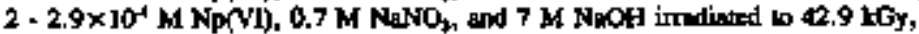

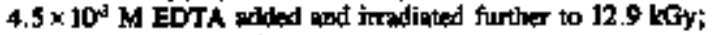

3 - solution (2) anter centrifugation

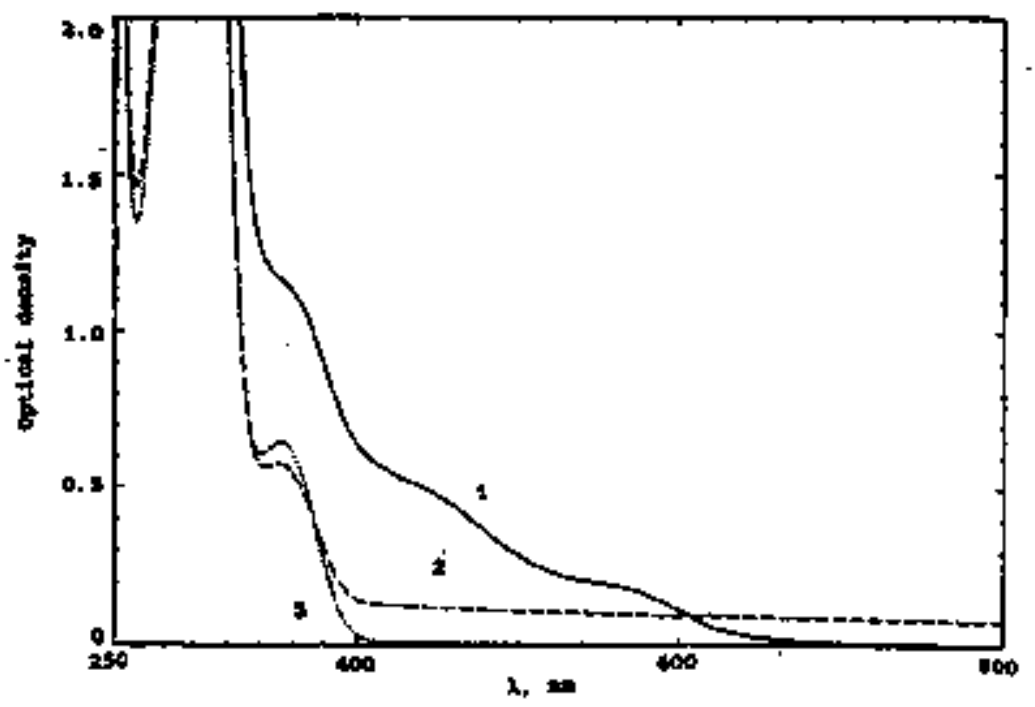




\subsection{GAMMA RADHOLYSIS OF ALKALNE AQHEOUS SOLOTIONS OF NEPTUNIUM(V)}

Neptonlum(V) in alkaline aqueouts solutions is teduced to Np(TV) on $\gamma$-irrediation. This behavior was demonstraled by the funmation, tow ac retatively low doses, of firidy diepersed

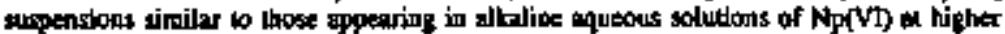
doses. This phenomenon is shawn in Figure 3-16 for alkaline Np(V) salution corallainime a sm:ll amoun of Np(VI). The fagure shows that the optial atsorption of the solntion incresses as a resull of irmdiution (becanse of light semtering on dispersed partictes); on

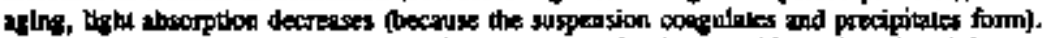
Additionar irratation again increases the light ghorption bectanse $N_{p}(V)$ is reduced further and a finely dispersed suspenston forms. In other woods, as in the cave of radiolytic reduction of Np(V) (see Section 3. I), a peculiar "opcilyation" process is abserved.

The precipitate coraists of predamisantly Np(T) ocompounds. This comclusion is confirmed by Fizure 3-17, ahich shows the optical absorption spectrum of the solvtion obeanined by dissolving the peciptate in $2.1 \mathrm{M} \mathrm{HCO}$. The precipilate was obtpined after cemtrifugation of imettented (dose $21.5 \mathrm{kGy}$ ) solution that oniginally contained $2.7 \times 10^{-4} \mathrm{M} \mathrm{Np}(\mathrm{V}, 0.16 \mathrm{M}$ HCOO and 4.5 M NaCt. In this solution, the ratio [Np(TV))TNP(V)] is 6:1. The presence of $\mathrm{NP}(\mathrm{V})$ seems to be caused by its coppoure as Uhe precipitste forms.

Obriously, NP(V) is reduced by the hydrated electom (Eicaction 9). Note that in the alpiline solntions studied, virmally all $\mathbf{H}$ atoms art converted to hydrated alextrons by way of

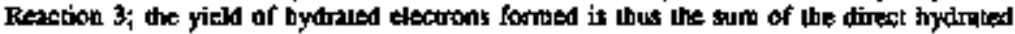
electron yield and the yideld of the $\mathrm{H}$ alom:

$$
G\left(E_{-4}^{-}\right) \cdot G_{4}+G_{x}
$$

Hydrated electrons also react wth axygen (Reaction 6). The fracion $f$ of hydruted electrons perticipating in Reation 91 s:

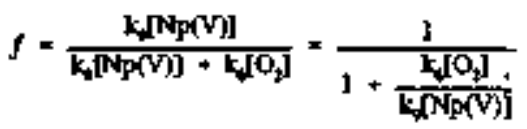

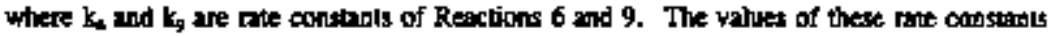

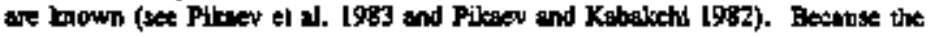

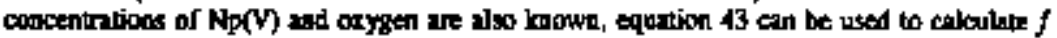

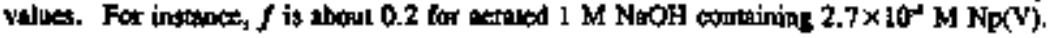


Figurv 3-16. Optical Absorption Spectre of NaOH, Np(V), and NpeVt) Solutions.

I - I.54 $\times 10^{-1} \mathrm{M} \mathrm{Np}(\mathrm{V}), \mathrm{L} .2 \times 10^{-1} \mathrm{M} \mathrm{Np}(\mathrm{VD}$, and $6.9 \mathrm{M} \mathrm{NaOA}$;

2 - sohulion (1) afker intodiation to $13 \mathrm{kOy}$ :

3 - solution (2) afiar standint 17 bours, 10 mintses;

4 - sohution (3) further inmatiated by 13 kOy

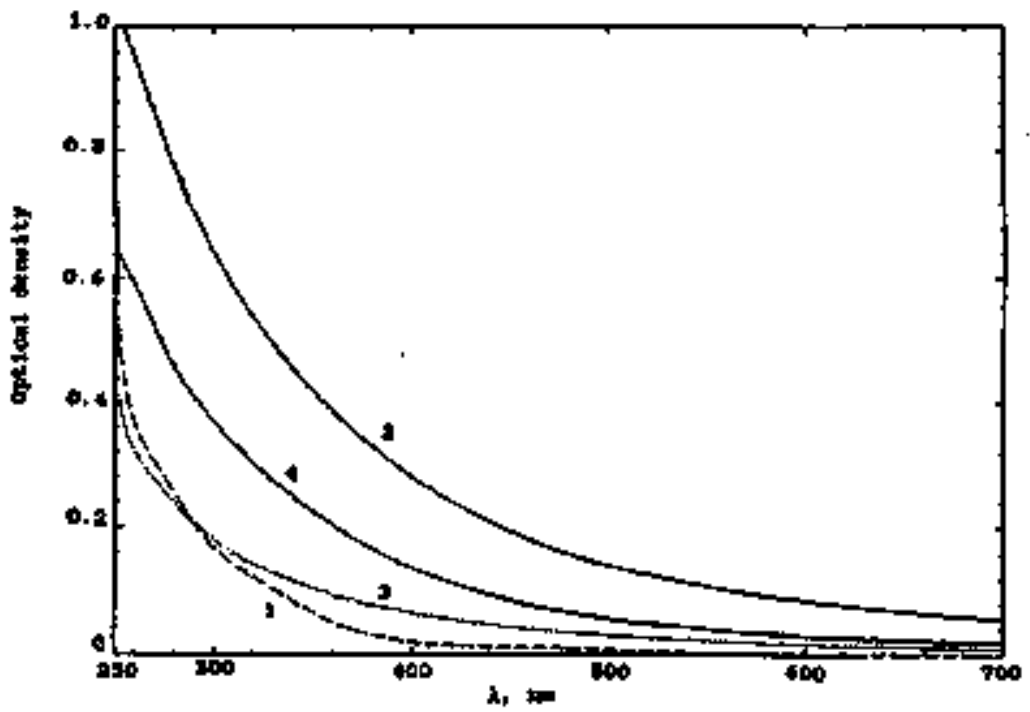


Fiture 3-17. Optical Absorption Spectrum of Dissolved Precipilate from Imadialad $\mathrm{Np}(\mathrm{V})$ Sabutions.

Precipitine ditsolved in $2.1 \mathrm{M} \mathrm{HClO}$; precipinte produced by centrifugation of solution contrining 2.7 $\times 10^{+} \mathrm{M} \mathrm{Np}(\mathrm{V}), 0.16 \mathrm{M} \mathrm{HCOO}$, and $4.5 \mathrm{M} \mathrm{NaOH}$ and intialed to 21.5 kOy.

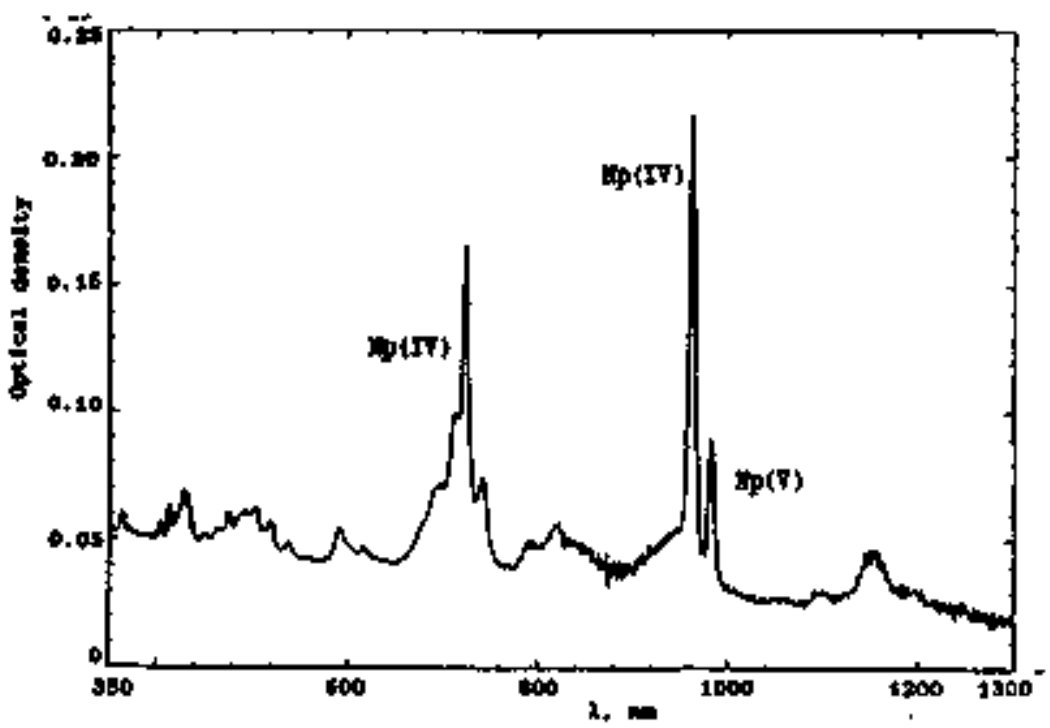




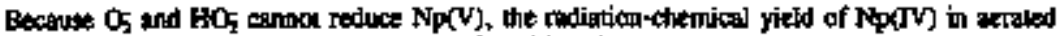
alloline Np(V) solutions in the abseace of additives is expressed by the equation:

$$
\mathrm{G}[\mathrm{Np}(\mathrm{TV})]=f\left(\mathrm{G}_{\mathrm{q}}+\mathrm{G}_{\mathrm{G}}\right)
$$

Radieal ions or and 0 ; (product of Reaction 19) oxitize Np(V) w Np(VI). Neptundum(1V) is shiphly soluble; therefore, the reactions of Np(IV), present in solin phase, whe $\sigma^{-}, \mathrm{O}_{3}$.

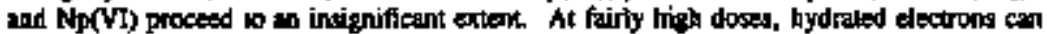
also reduce Np(V). The studies bave shown livt equation $4 \mathbf{A}$ expresses the maximum yalue of the yleld. Experimental yedd values can be described by the fallowing expression:

$$
G\left[N_{p}[\text { IV })\right]<f\left(G_{4}+G_{n}\right)
$$

The presence of formale, HCOO, ansses coO redical ion formstion (Reaction 31). These

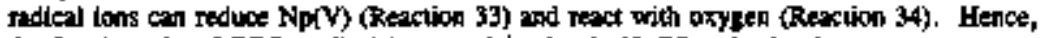
the fraction, $f_{1}$, of COO nedteal ions participating in Npr $(v)$ reduction is:

$$
f_{1}=\frac{k_{y}\left[N_{p}[V]\right.}{k_{y y}\left[N_{p}(V)\right]+k_{y}\left[O_{2}\right]} * \frac{1}{1+\frac{k_{-1}\left[O_{2}\right]}{k_{n}\left[N_{p}(V)\right]}}
$$

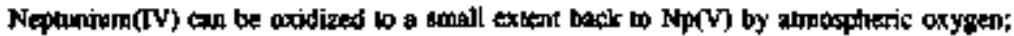

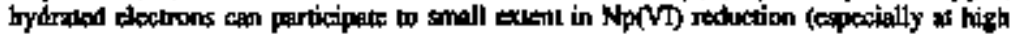

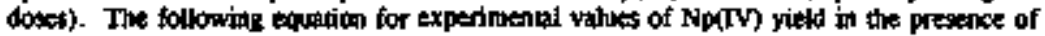
formate topreses these Ielationshipt:

$$
\mathrm{GNpOVI]}<f\left(\mathrm{G}_{\dot{q}}+\mathrm{G}_{\mathbf{H}}\right)+f_{1} \mathrm{G}_{o+1}
$$

Note also that Np(TV) is not alable follewing imatiation and is alow]y oxidized in the imadiated salution lo Np(V) by oxygen and ndidytically produced hydrogen peroxidte.

Gamma radialysis of alkaline aitrak Np(V) solitiong, as for similas Np(VI) solutions, resalts in $\mathrm{Np}(\mathrm{V})$ perous complex kormation. Nitrike has the same influeace for $\mathrm{Np}$ (V) as for $\mathrm{W}$ (VT) alkalipe solutions. The formation of the Np(V) peroxo complex is shown in Figure 3-18; the inhibiting influence of nitrike is shown in Figure 3-19.

These effects are explained by the "protection" of Np(V) by NOS 10 reduction and the reaction of pirrite with hydrogen peroxide. Hydrogen peroxide is decomposed by $\mathrm{NO}_{\text {j- }}$

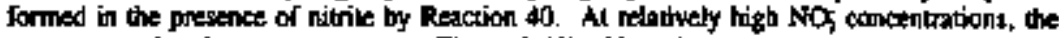

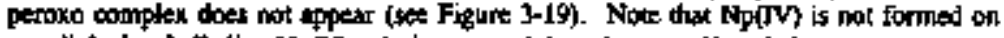
cradiolysis of allaline $\mathrm{Mp}(\mathrm{V})$ solutions containing nitrate and/or nitrik. 
Figure 3-18. Optical Absorption Spectre of $\mathrm{kaOH}, \mathrm{NaNO}$, and $\mathrm{Np}(\mathrm{V})$ Salutions.

1 - $5.8 \times 10^{+} \mathrm{M} \mathrm{Np}(\mathrm{V}), 0.16 \mathrm{M} \mathrm{NaNO}$, and $3 \mathrm{M} \mathrm{NaOH}$;

2 - sodution (1) invadizied to 17.9 LGy

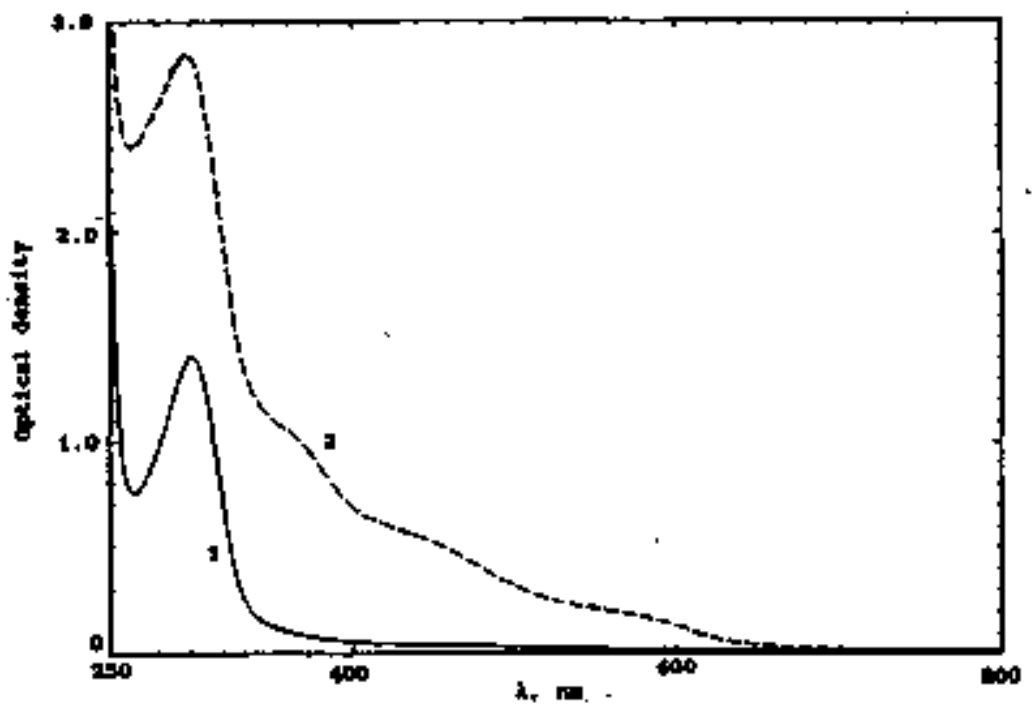


Figare 3-19. Optcal Absometion Spectn of $\mathrm{NaOH}, \mathrm{NaNH}$, $\mathrm{NaNO}_{2}$, $\mathrm{Np}(\mathrm{V})$, and Np(VT) Solvtions.

I. $1.6 \times 10^{-4} \mathrm{M} \mathrm{Np}(\mathrm{NT}) \& \mathrm{~Np}(\mathrm{~V}), 0.7 \mathrm{M} \mathrm{NaNO}$, and $3.6 \mathrm{M} \mathrm{NaOH}$;

2 - solution (l) irmatianed to 25.8 LGy;

3 - $1.8 \times 10^{4} \mathrm{M} \mathrm{Np}(\mathrm{VD}) \mathrm{NP}(\mathrm{V}), 0.7 \mathrm{M} \mathrm{NaNO}, 0.01 \mathrm{M} \mathrm{M} \mathrm{KNO}$, and $3.6 \mathrm{M} \mathrm{NgOH}$ irmilinut to $25.8 \mathrm{kOH}$

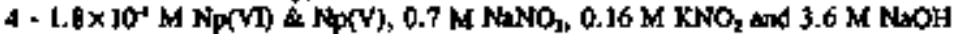
impdiand $1025.8 \mathrm{kgy}$

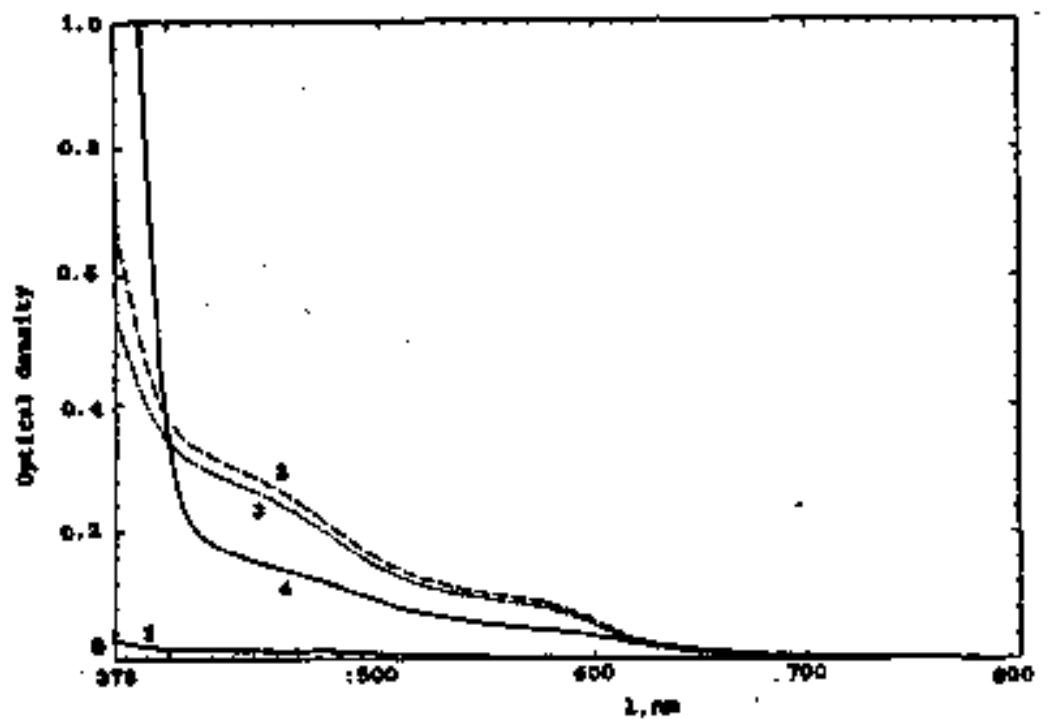




\subsection{GAMMA RADTOLYSS OF ALNALWE AQUEOUS SpLUTIONS OF FLUTONIUM}

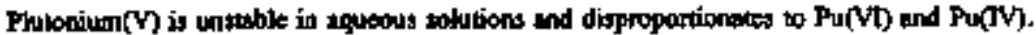

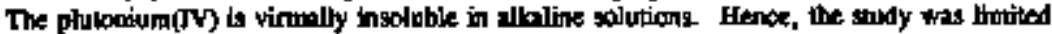

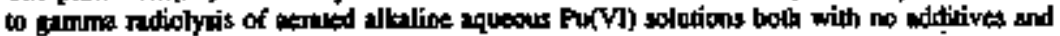
in the presence of same additiryts.

\section{4,1 GAMMA RADIOLYSS OF ALXALINE AQUEOUS SOLUTHONS OF

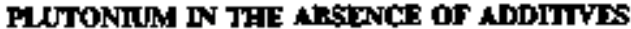

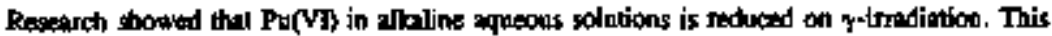

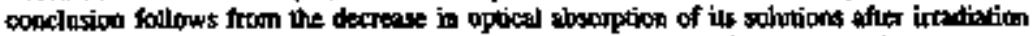
(see Fizune 4-1). At comparatively high doves (over aboux 2 kGy), the solution bexplo signifiently wrid in all solutions studied. Fisure 4-2 showl this effect for the solution of Pu(VI) in I.3 M NaOH. The tolld phatex lommed ts vecy finely dispereed and prelonged centrifugation (over 40 minutes) is sequired for its soparation. The arbidity is especially

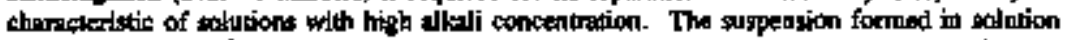
containing $1.9 \times 10^{\circ} \mathrm{M} \mathrm{Pu}(\mathrm{VT})$ and $1.3 \mathrm{M} \mathrm{NrOH}$ iradiated to 4 kGy dose precipizbed sponbareobsly (without centrifupation) after sboul 24 bours. It is noled that at redativity high doses, corplete conversion of Pu(VT) to Pu[lV\} oxcurs.

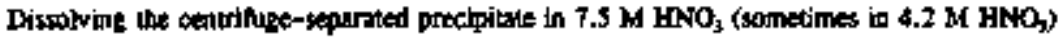

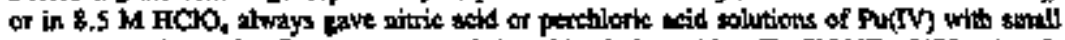

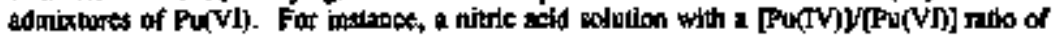
about 12:I was formed after dissolvins the precipitale from the irradialed (dose jo tGy) $1.3 \mathrm{M} \mathrm{NaOH}$ solntion in $7.1 \mathrm{M} \mathrm{HNO}_{3}$ (see Figure 4-3). A solution of the same compotition.

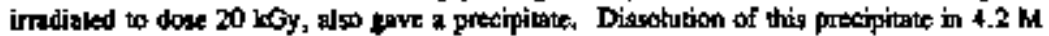
HWO, produced Pu(TV) golution contrining no Pu(V) (ske Floure 4-4).

Radlation-chemient yields of PU(V) reduction were measured at doses of less lhar I rGy for solutions with various concentritions of alkali. The dath obnined are shown in Table $4-1$. Baed on thete data, the allali concestration clearly has thtte efTect in the yield.

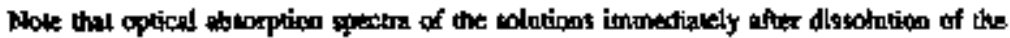
precipitater differed from the spoctur of the sohulions prepared Gona indivitual Pu(TV) compounds. After the solntions were glored for 16 hours, the pectar became identical to hose of indwidunl Pu(IV) compound solutioas (see Figure 4-5). This effect 1thely is cauted by the prevense of colloid colutions of Pu(TV) in the firs stage of presipibte dissolution. 


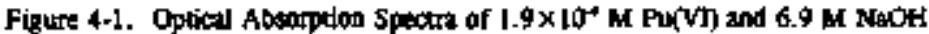
Schthion as a Fupation of Dost.

Dose, kGy: $1-0 ; 2-0.22 ; 3-0.45$

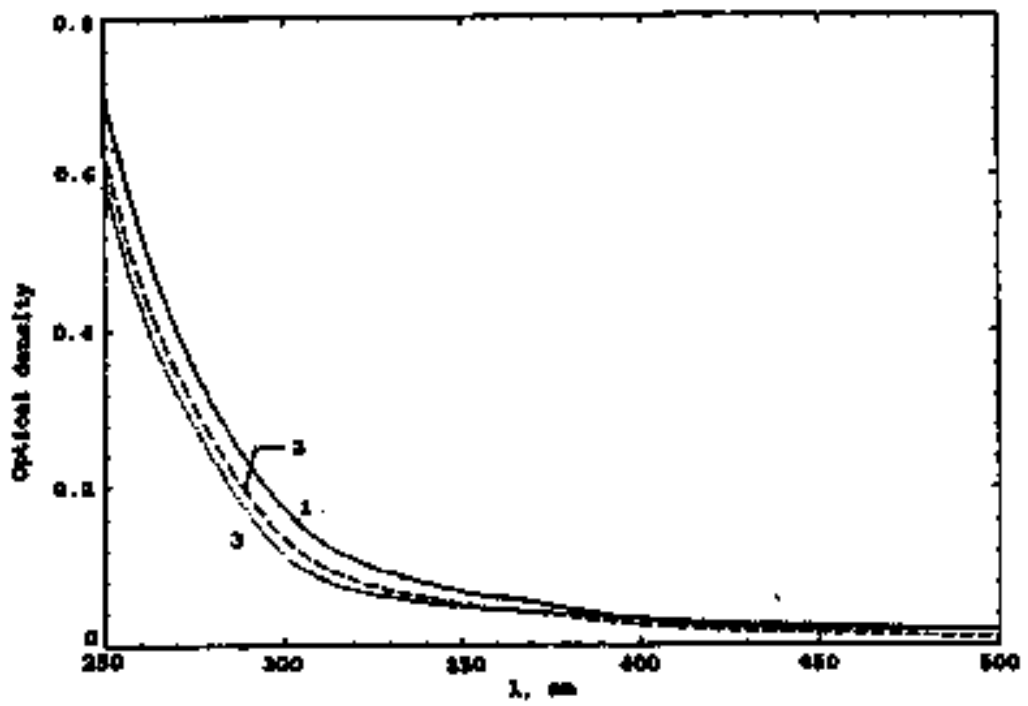




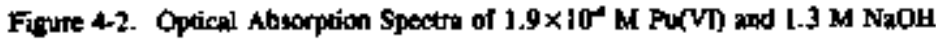
Sidution as a Function of Dose.

Dose, $120 y: 1-0 ; 2+4,3 ; 3-8.6$

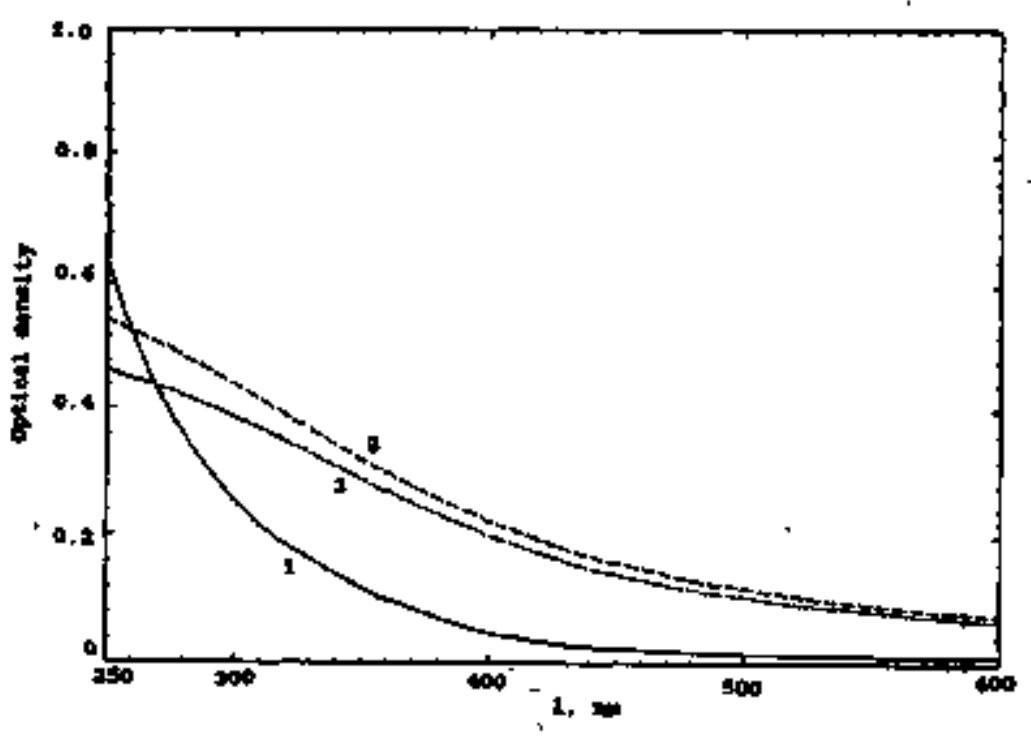


Figure 4-3. Cptical Absorption Spectrum of Dissolwed Precipitates fram IO kGY Irradiated Pu(VT) Solvuon.

Precipitases dissolved in 7.1 M HNO,; precipitates produced by $10 \mathrm{hGy}$ irradlation of solution conteining $1.9 \times 10^{-} \mathrm{M}$ Pu(VT) and $1.3 \mathrm{M}$ NaOH.

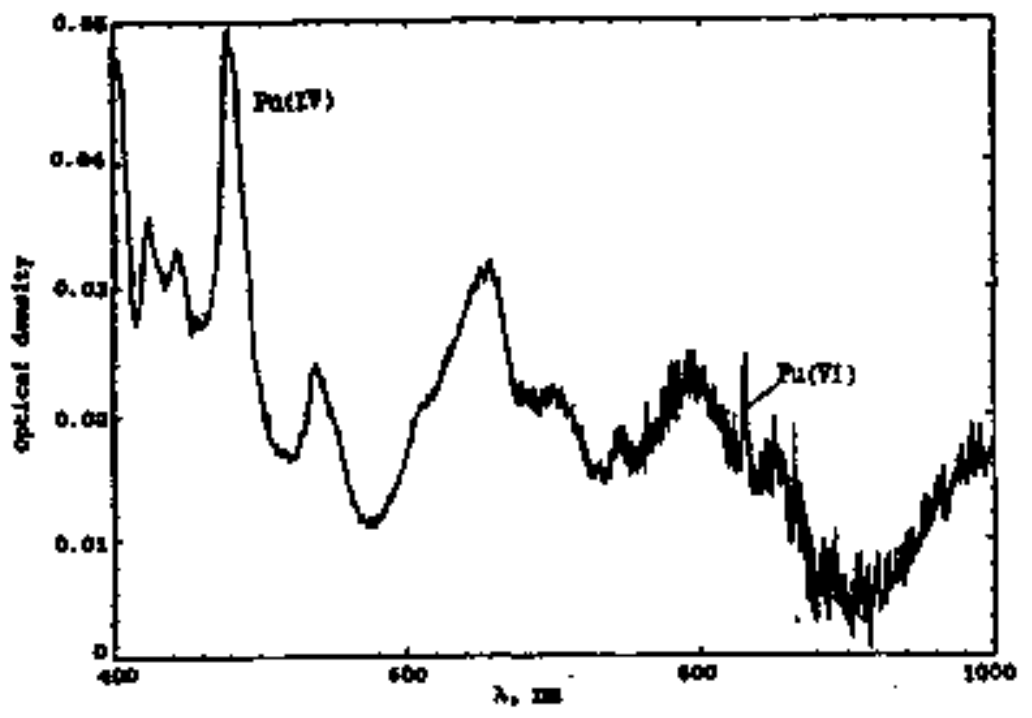


Figure 4-4. Optital Absompion Spectram of Dissolved Precipibites from 20 kGy Jrradiated Pu(VT) Solution.

Preciplanas dissalved in 4,2 M ANO,; procipitates prodeced by $20 \mathrm{kGy}$ irmatiplion of

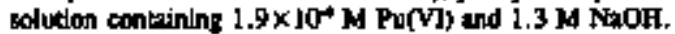

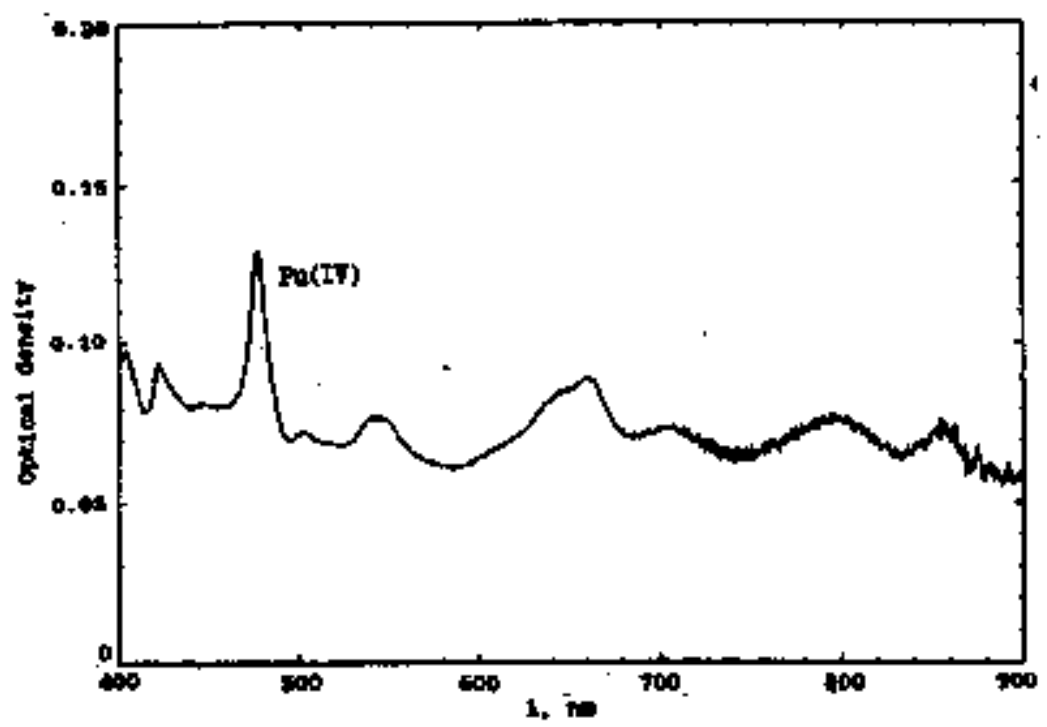


Finule 4-5. Optical Abockion Specter of Dissolved Procipitates form 20 kGy Indiatad Pu(VI) Solution -. Effact of Dissolution Time.

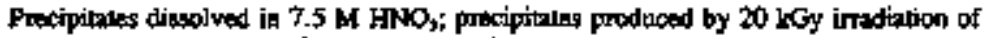
solntion contining I $x$ 10' $\mathrm{N}$ Pu(VI) and $8.5 \mathrm{M}$ NeOH.

Time afle irradiation, hours: I - 0;2 - 16

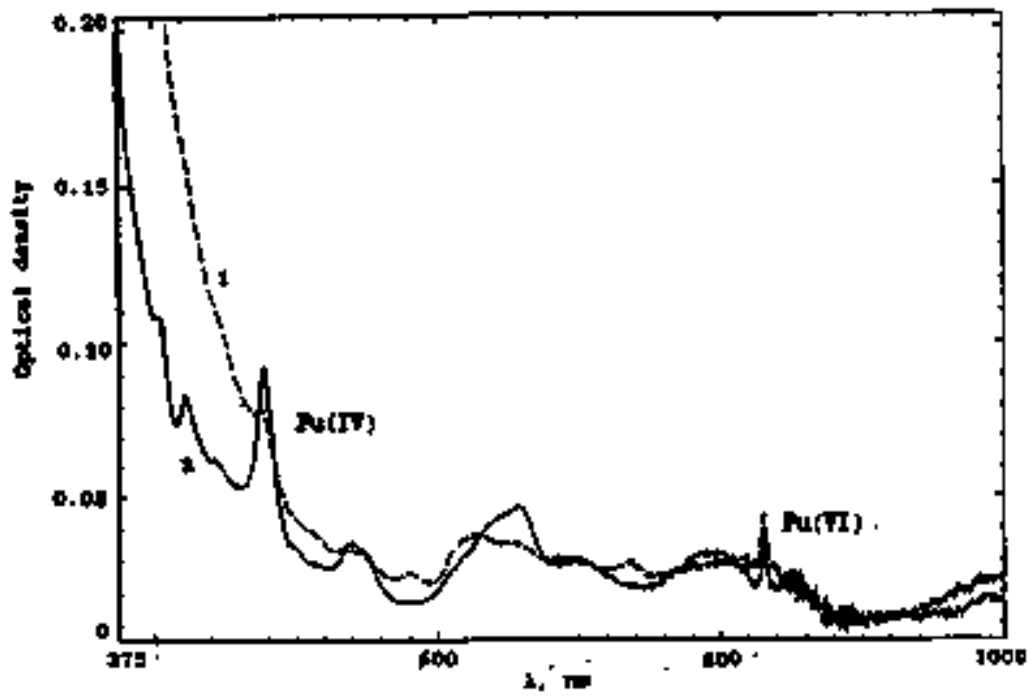

$-$ 


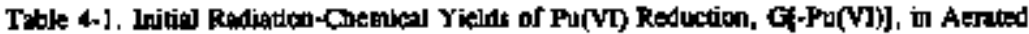
Allutine Aquecus Solutions.

\begin{tabular}{|c|c|c|}
\hline 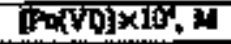 & 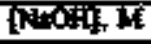 & 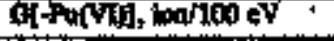 \\
\hline 2.2 & 1.3 & 1.4 \\
\hline 3.3 & 6.3 & 1.3 \\
\hline 2.0 & 6.9 & 1.5 \\
\hline
\end{tabular}

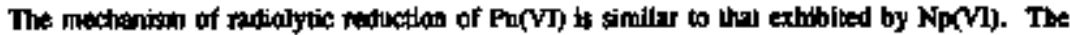
only fifference is that Pre(v) is unstrble and dispospourtionites by the reactios:

$$
2 \mathrm{~Pa}(\mathrm{~V}) \rightarrow \mathrm{Pu} \text { (IV) }+\mathrm{Pu}(\mathrm{VI})
$$

The precipilation of Pu(JV) to form a solid phase restriets ins ractidstion by water radiolysis products. The cediation-chervical yield of Pu(V) may be described by the equation:

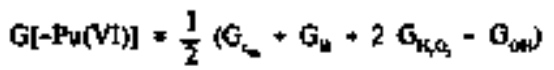

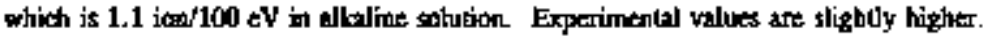

\subsection{GAMMA RADTOLYSS OF ALKALINE AQUEOLS SOLUTIONS OF PLUTONIUM IN THE FRESENCE OF ADDTTYES}

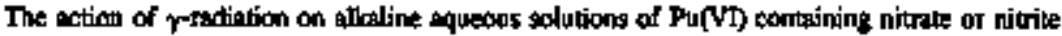
leads to the formation of finely dispersed suspengions. Dissolution of the prectpilates, separated frem intodiated solvtions by centrifugation, in $7.5 \mathrm{M} \mathrm{HNO}$ or B.5 M HClO, gave acid solutions of Pu(TV) wilh sandl admixures of Pu(VT). A simllar phenomenon was observed in the cave of Pu(VI) wolutiont contining EDTA.

In schutions containing nitrate or pitrite, the produced hydrated electrons reacl readily wh NO; or NO; to form the correspowding radical ions. The Pu(V) then is rechuced by reacting with NOt, NOj,; hydrogen peroride, or simikr agents. The Pu(V) peroxo complex identified in the literature (Mosikns 1971) pass box observed in solutions comaining nitrale (possib]y because of dispropontonation of Pu(V) or because of the riporisdly low stability of the complex at room emperinire).

In solucions contrining EDTA, retuctlond of Pa(V) proceds by tetations with the hydrated electros and hydrogen perimcide. Froe molicals from EDTA, produced by its reaction with OH (O), apperently do bol resct with Pu(VT). Unfortunately, the radiation-chenieal yelds of Pu(VT) faduction in soluticas containing the invertigaled wdditives could not be determined becalles, etoh at low doset, a tineby dispersed suspension formed. 


\section{WHC-EP-Q901}

This page tnentrousilly lef blank.

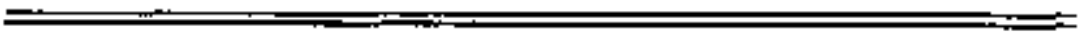




\section{GAMMA RADIOLYST OF ALXALNE AQUTOUS SOLUMONS OF TECENETUM}

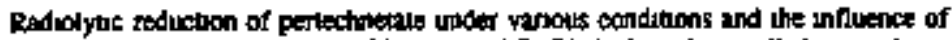

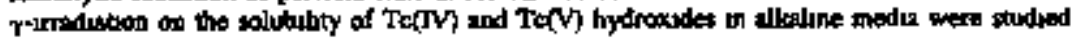
in thes work

\section{S.1 RADIOLYTLC AEHJCTION OF PERTECHNETATE}

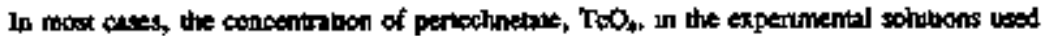
was $5 \times 10^{3} \mathrm{M}$ No net reduction of pertucturetale whs observed an $\gamma$-rodbolysis of its aented

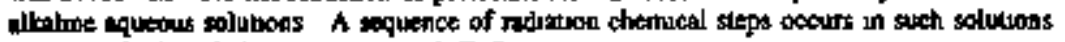
Furst, the hydroted electron reacts with TeO.

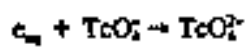

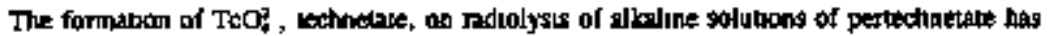

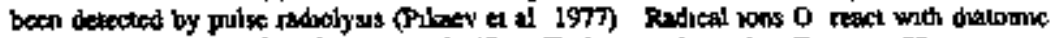

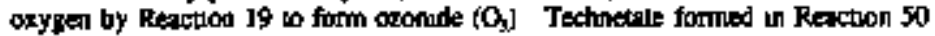
diproportionales and is oxidized by oxbalde

$$
\begin{aligned}
& \mathrm{TcOd}+\mathrm{TcOH}^{2} \rightarrow \mathrm{T}_{\mathrm{O}} \mathrm{O}_{4}+\mathrm{TcO}^{2} \\
& \mathrm{O}_{3}^{2}+\mathrm{TeO}_{4}^{2+}+\mathrm{Br}_{3} \mathrm{O} \rightarrow \mathrm{TeO}_{4}^{+}+2 \mathrm{OH}_{+}+\mathrm{O}_{2}
\end{aligned}
$$

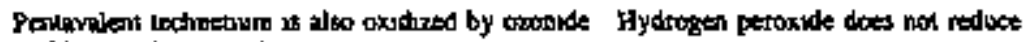
Te(VII) ut alkaline solution

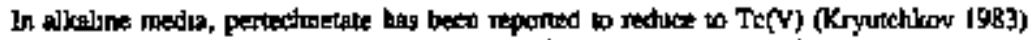
Tbe yield of TCO, reducton, expressed in the following equethon, refiecli the effects of Reaxions 50 to 52

$$
G\left(-T+O_{4}\right) \cdot \frac{1}{2}\left(G_{i} \cdot G_{k}-G_{0 m}\right)
$$

By the caleulabon, the yeld in $1 \mathrm{M}$ NoOR should be 035 ron $100 \mathrm{eV}$ However, the reduction is bor observed Apparently, thus is because reactions with hydmegen peroxide ocete (in addtom to Reictions 50 to 52)

$$
\mathrm{HO}_{2}+\mathrm{TCO}_{2}^{2}+\mathrm{H}_{2} \mathrm{O}+\mathrm{TO} \mathrm{O}_{2}+\mathrm{OH}+2 \mathrm{OH}
$$




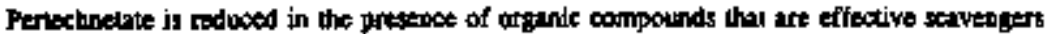

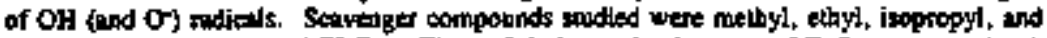

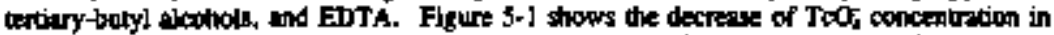

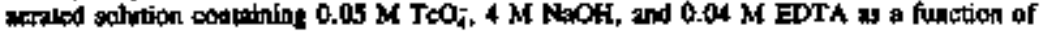

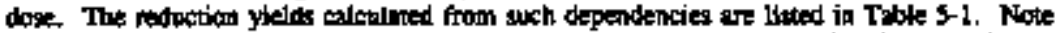
thal the vilues of ylelds are approximake becallse the procigion to dekermine p-radipativity

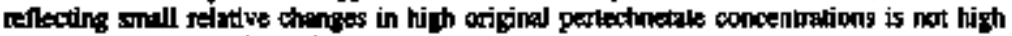
(1.e, not better than 25 to 35 . 
Figure 5-1. Dependanc of ThOי, Combentration on Dase in Aergted Aqueous Solotion Containing $4 \mathrm{MS} \mathrm{NoH}$ and $0.04 \mathrm{M}$ EDTA.

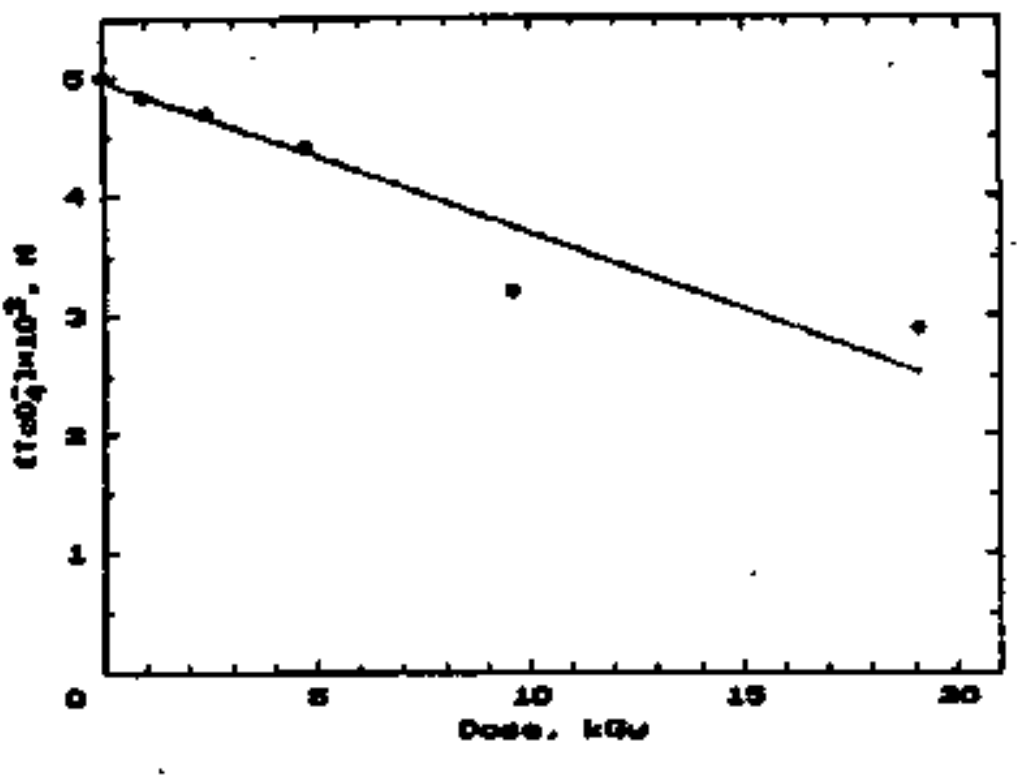


Table 5-1. Radation-Chemicl Yiplds of ToO; Redvetion [G[-TcOS)] in Aerater Aquous Salutions.

$\left[T 00 ; 1=5 \times 10^{-3} \mathrm{M}\right.$

\begin{tabular}{|c|c|c|c|}
\hline 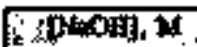 & . 'Y' & Dow boy & 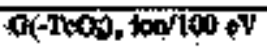 \\
\hline 4 & None & To 20 & 0 \\
\hline$\overline{L 4.6}$ & None & To 20 & $\overline{0}$ \\
\hline 4 & CH,OH, 0.1 MA & $\overline{2.5} \overline{5}$ & $\overline{2.5}$ \\
\hline 14.6 & $\mathrm{CH}_{\mathrm{Y}} \mathrm{OH}, 0.1 \mathrm{M}$ & $2.5-5$ & $\overline{2.8}$ \\
\hline 4 & $\mathrm{C}_{2} \mathrm{H}_{3} \mathrm{OH}, 0.1 \mathrm{M}$ & $1-20$ & 2.7 \\
\hline 14.6 & $\overline{\mathrm{C}_{2} \mathrm{H}_{5} \mathrm{OH}, \mathrm{O} . \mathrm{I} \mathrm{M}}$ & $\overline{5}$ & $\overline{2.6}$ \\
\hline 14.6 & 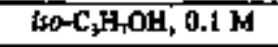 & 5 & 5.5 \\
\hline 4 & Sert-C,H,OH, O.1 M & 1.20 & 1.0 \\
\hline$\overline{14.6}$ & tert-C,H,OH, O.I M & 1.20 & 1,4 \\
\hline 4 & EDTA, 0.04M & $1+20$ & 1.2 \\
\hline 14.6 & EDTA, 0.04M & 10 & 1.1 \\
\hline
\end{tabular}

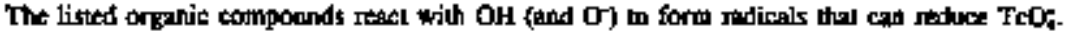

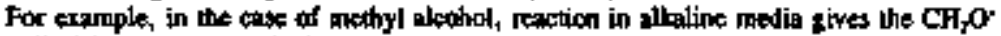
radipal ion, a gorodig reductiong agent:

$$
\begin{gathered}
\mathrm{CH}_{3} \mathrm{OH}+\mathrm{OH}(\mathrm{O}) \rightarrow \mathrm{CH}_{2} \mathrm{OH}+\mathrm{H}_{7} \mathrm{O}\left(\mathrm{OH}^{\prime}\right) \\
\mathrm{CH}_{2} \mathrm{OH}+\mathrm{OH}^{-}+\mathrm{CH}_{2} \mathrm{O}^{-}+\mathrm{H}_{7} \mathrm{O}
\end{gathered}
$$

The aros probable feaction of this radical ion is:

$$
\mathrm{CH}_{2} \mathrm{O}+\mathrm{TeO}_{2} \rightarrow \mathrm{TeO}_{2}^{2}+\mathrm{CH}_{7} \mathrm{O}
$$

Similar acactions occur foc thyl and, pospiby, iscopopyl alcohols.

Oxypem can repet bo form arganic peroxide radicals from the organdc frot raficols under consideration. However, this resction in the test solvotions is unlikely because the

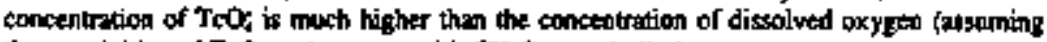
the reactivities of $\mathrm{TeO}_{4}$ and oxysen with $\mathrm{CH}_{2} \mathrm{O}$ are gimilar).

Because hydrogen peroxite dows nol roduse perkechneble, the expected redurtion yield in late preserver of the rested aleohols an be calculated:

$$
G\left(-T c 0_{1}\right)=\frac{1}{2}\left(G_{L}+G_{H}+G_{O N}\right)
$$




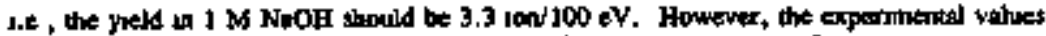

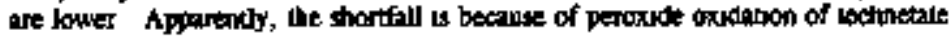
(Reaction 54)

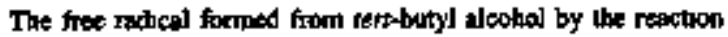

$$
\left(\mathrm{CH}_{3}\right)_{1} \mathrm{COH}+\mathrm{OH}\left(\mathrm{O}^{-}\right) \rightarrow\left(\mathrm{CH}_{2}\right)_{2} \mathrm{CH}_{2} \mathrm{COH}+\mathrm{H}_{3} \mathrm{O}(\mathrm{OH})
$$

If nox a reducang agent. Hence, the praximum yneld of the reduction should be expressed by the equition

$$
\mathrm{G}\left(-\mathrm{TCO}_{\mathrm{H}}\right)=\frac{1}{2}\left(\mathrm{G}_{\mathrm{m}}+\mathrm{G}_{\mathrm{H}}\right)
$$

Thus yeld stould be I 8 josf 100 eV The lower expenmental values abgerved agent linely

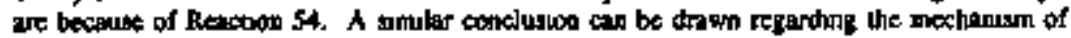
$\gamma$-ramolyst of the solutions contaraing EDTA

\section{S.2 RADIOLYTIC OXWATHON OF TCTV AND TaC EYDROXIDES}

Pentavaleat texhnetum un alkalune mothe is sparngly soluble. It exiss in the form

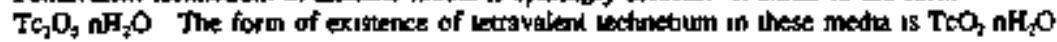

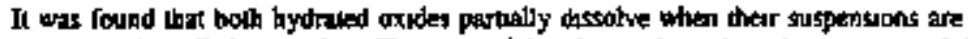
$\gamma$-irradraded in alketine medra The rated of dissolution depend ap the presence of the other

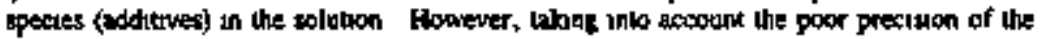

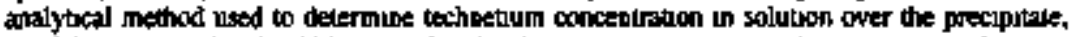

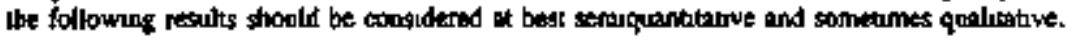

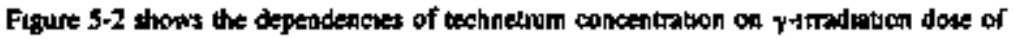
$\mathrm{TCO}_{2} \mathrm{aH}_{2} \mathrm{O}$ slispensioss in solutoons whth varours conoentrations of allsal The dependencies for suppartions of $\mathrm{T} c_{3} \mathrm{O}_{1} \mathrm{nH}_{2} \mathrm{O}$ art represented un Figure 5-3 The examples lllustrating the

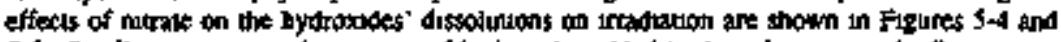
5-5 In all experments, the amount of hydroxides addod to the solution was $4 \mathrm{~g} / \mathrm{L}$

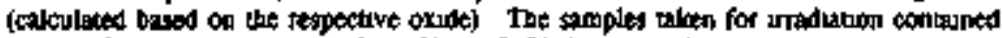

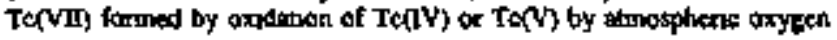


Figure 5-2. Dependence of Techneblum Contentition on Dose for

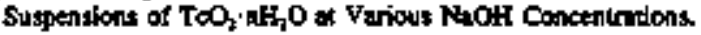

[N2Ot], M: $1-0.5 ; 2-4 ; 3-8 ; 4-15$

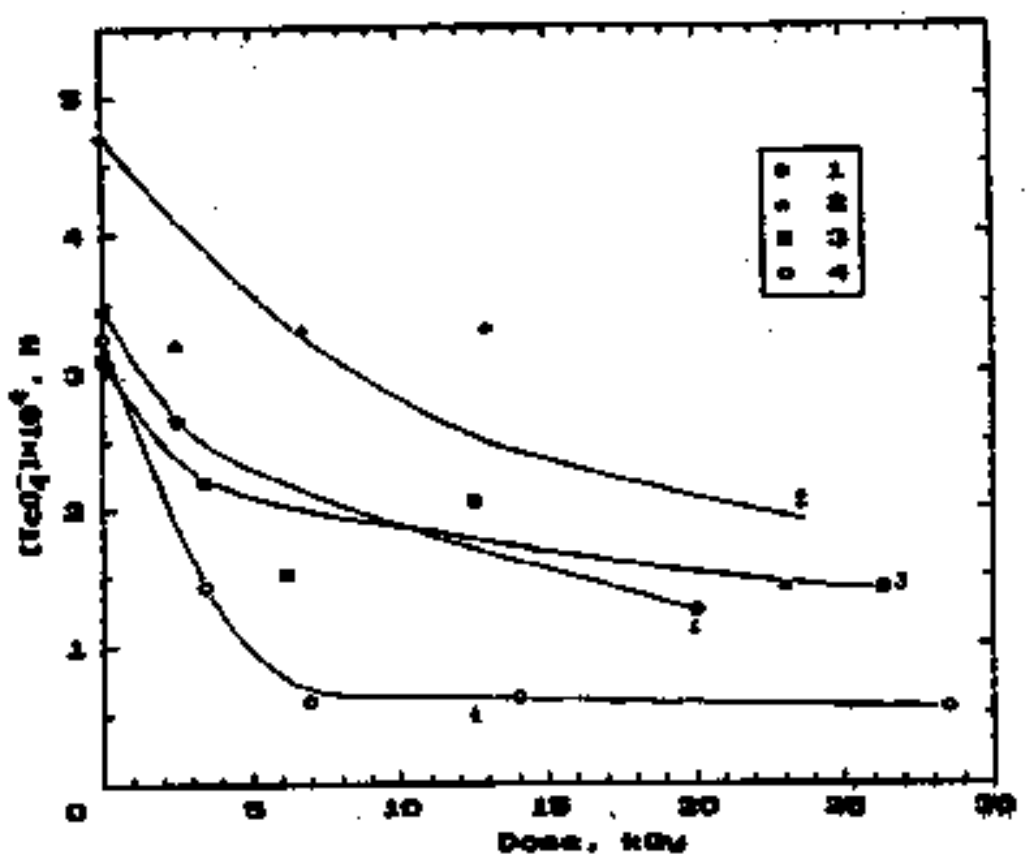




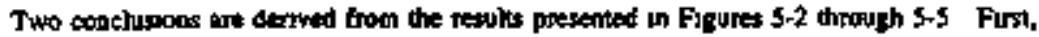

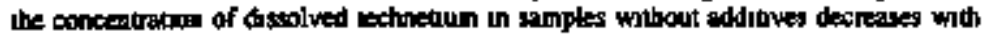

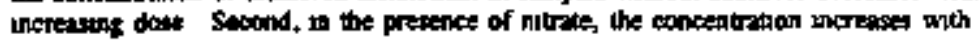

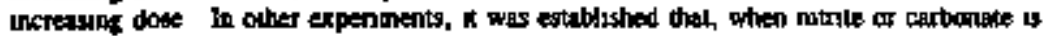
added, the poncentration decreanes wh increasing dose

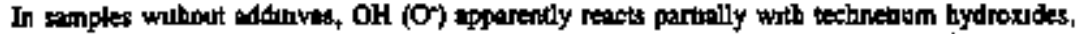

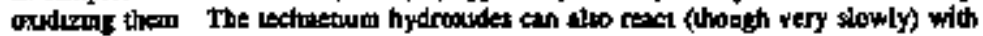

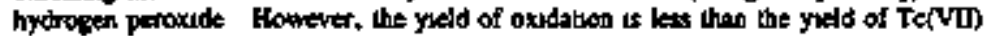
rednction (for example, by bydrind elections) The technenum concentribon dectesses in

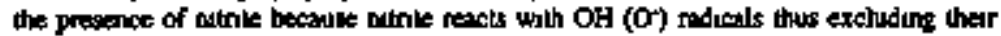

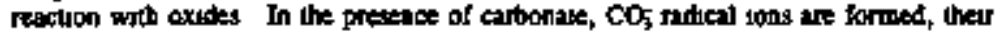

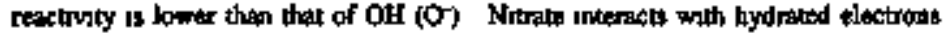

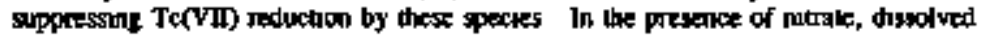
techneuum ucreanes with pacreased dose

In summary, the raphation-andped oxidation of Te(TV) and Te(V) hydraxides unereases th the presence of addrtives thal are scrvengors of hydrated electoons and decreases in the presence of addiuves that are scavengers of OH (O) radicals

The exidation of To(TV) and Te(V) bydroxides contakces after frTadiation This phenomenon

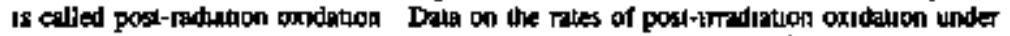
vanous experimentil condibons are shown in Tables 5-2 through 5.9

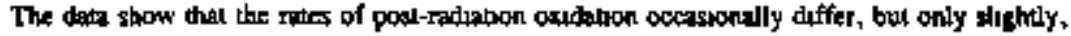
from those obstived un unirrdiated solutions In some cases (expexisily al hiph allall

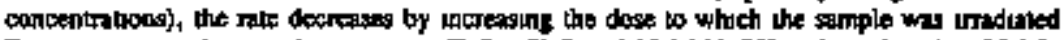

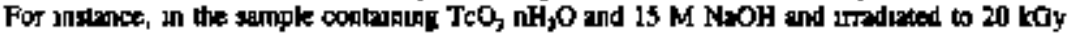

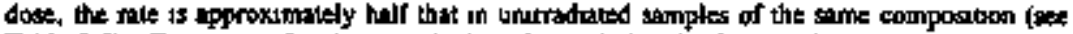
Table 5-2) Reactions of technebum bydroxides with thesolved atmolpheris oxyger and with

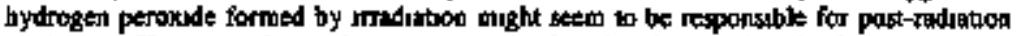

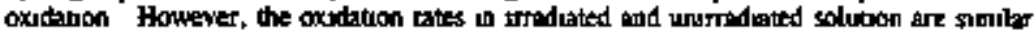
On thus basis, il appears that hydroffen permende does nod play an important role This may be because of low tadubiot-chendical yiths of hydrogen peroxide, or becouse of its fast

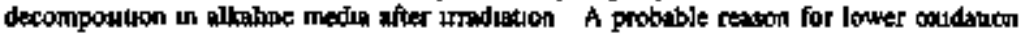
rikes in highly concentralod alkpl soluhion is the kover solubility of ur in such modua

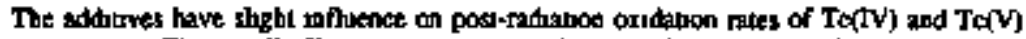
hydroxides This smill effect may only be a Ieflectron of thear smali iafluence on the

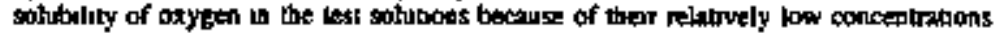


Fiqure S-3. Depeadence of Texhetium Concentribion on Doce for Supentions of $\mathrm{Te}_{2} \mathrm{O}_{3}, \mathrm{nH}_{j} \mathrm{O}$ a Varlous $\mathrm{NaOH}$ Concentrations.

(NaOH), B: $1-0.5 ; 2-4 ; 3-8 ; 4 \cdot 15$

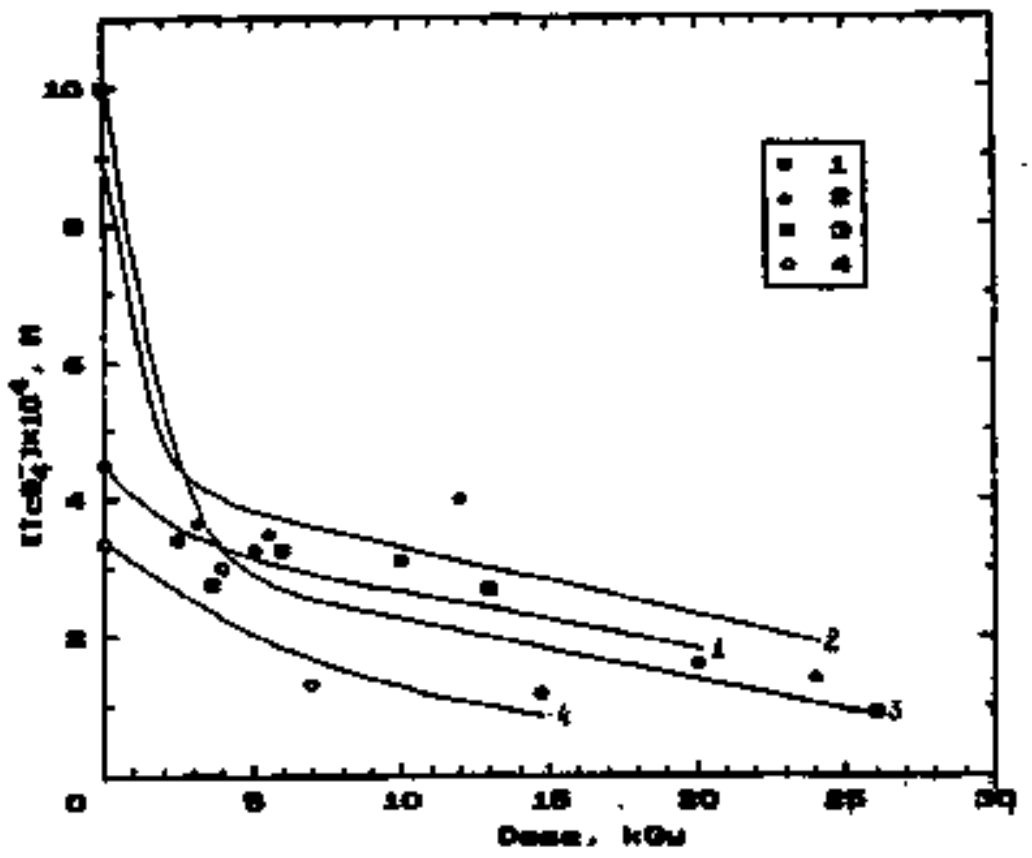




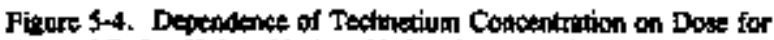

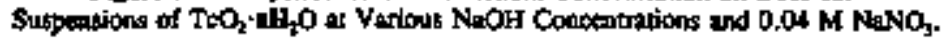

[NeOR], M: I - 0.5;2-4;3-8;4- 15

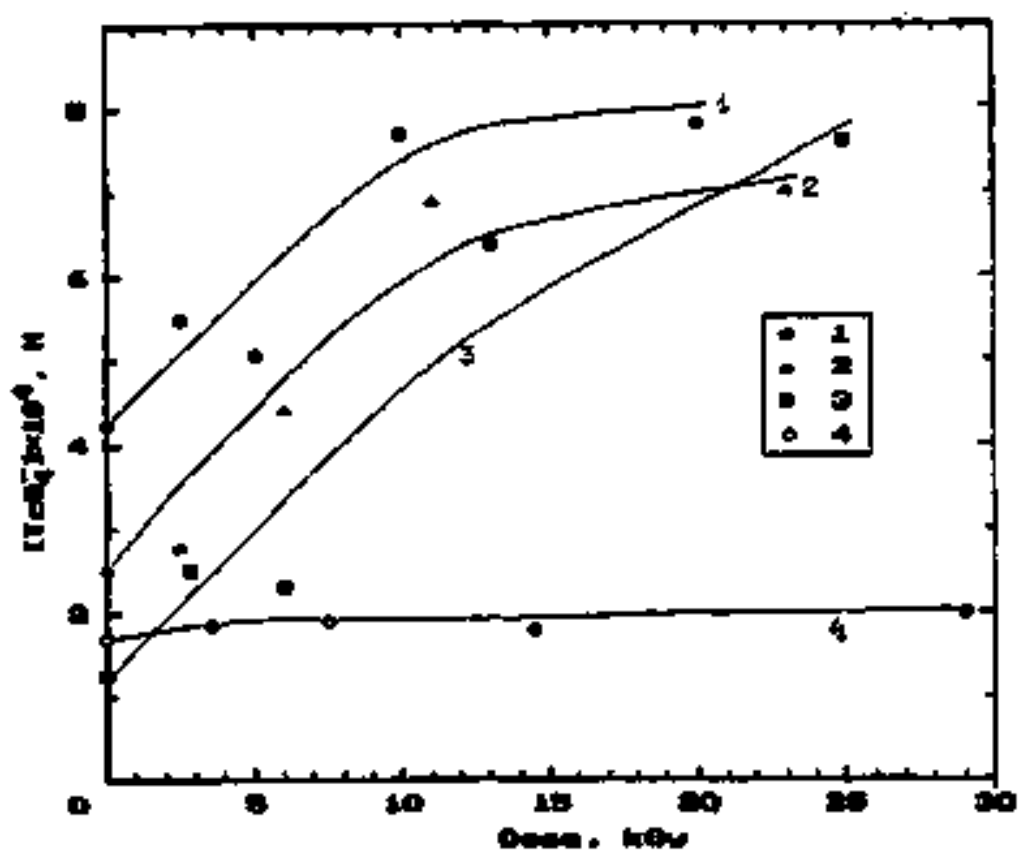


Figure 5-5. Deperdedoe of Testretiom Concentration on Dose for $\$ n$ spensions of $\mathrm{Tc}_{2} \mathrm{O}_{4} \cdot \mathrm{nH}_{2} \mathrm{O}$ al Varlous $\mathrm{NaOH}$ Concencritiont and $0.04 \mathrm{M}$ NaNO.

[NoH], M: I - 0.5; 2 - 4; 3 - B; 4 - I5

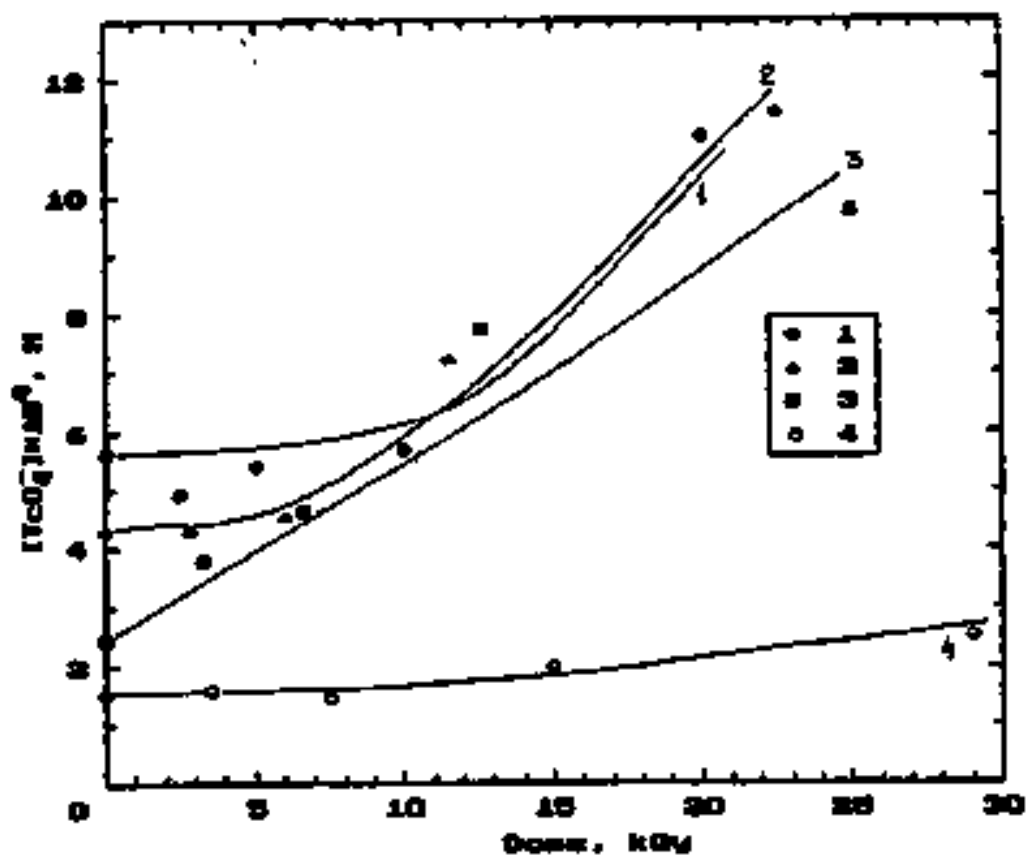


Table 5-2. Rates, $\mathrm{V}$, of $\mathrm{TCO}_{3} \cdot \mathrm{nH}_{2} \mathrm{O}$ Fost-Radiation Oxidation at Vations LbOF Coscenarations and Absoitbed Doses.

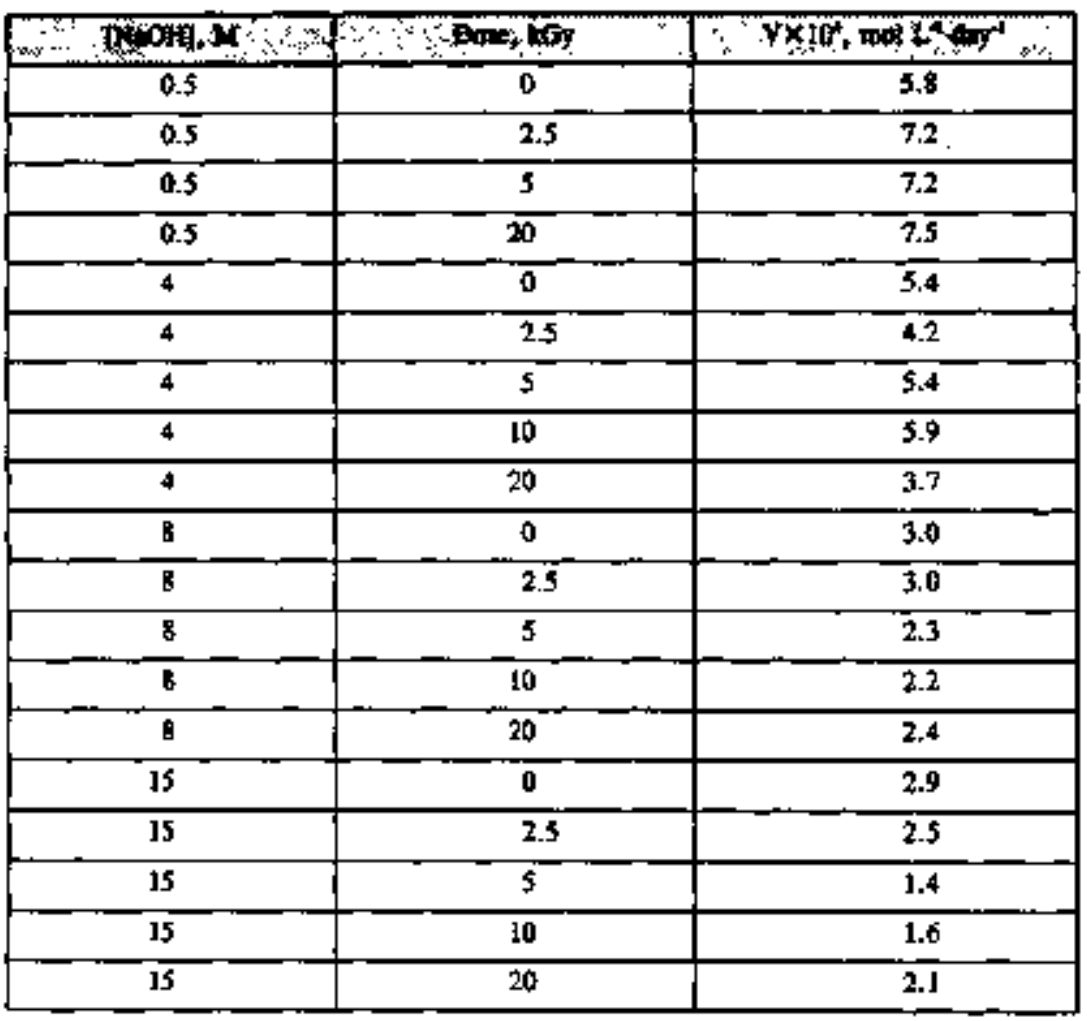


Thble 5-3. Rakes, $\mathrm{V}$, of $\mathrm{Tc}_{2} \mathrm{O}_{3}-\mathrm{nH} \mathrm{H}_{4} \mathrm{O}$ Post-Rodiation Onidation

at Various NaOH Concentrations and Absorted Doses.

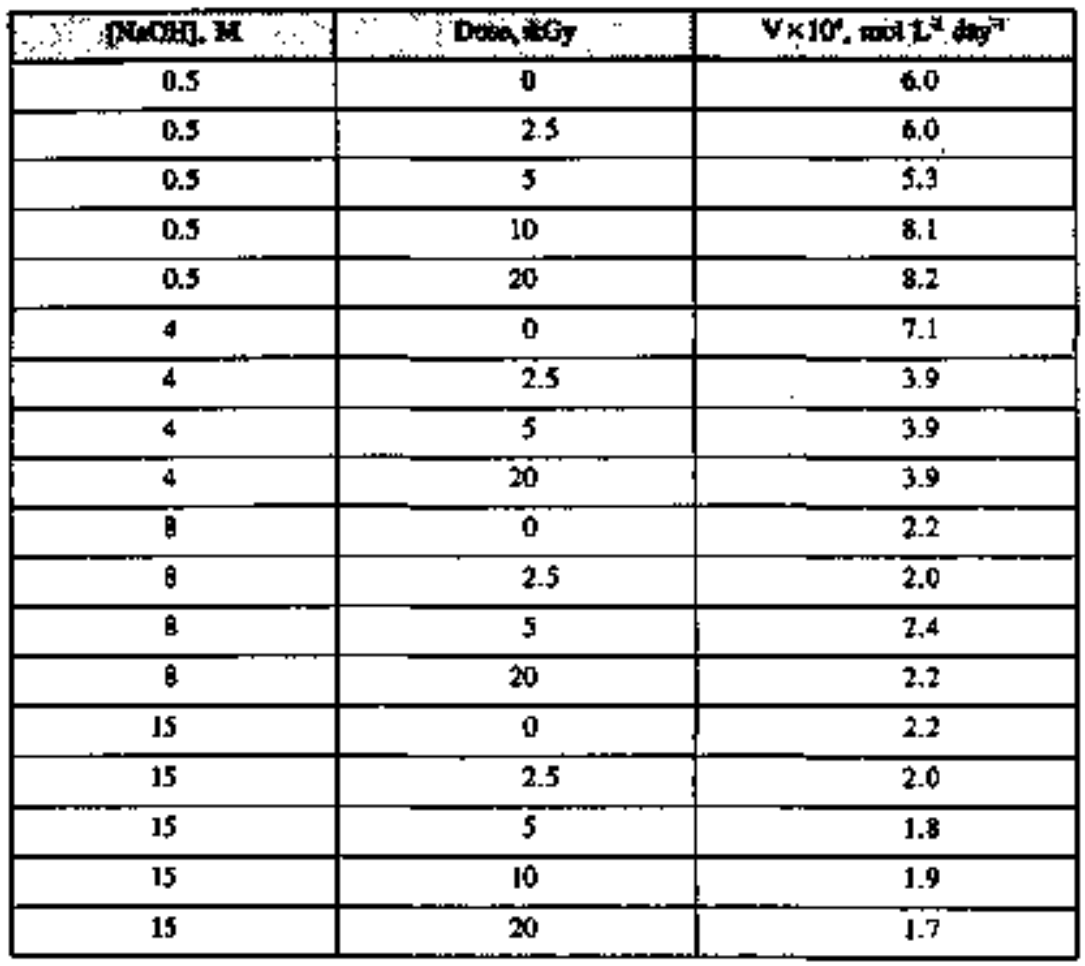


Table 5-4. Rave, $\mathrm{V}$, of $\mathrm{TeO}_{3} \cdot \mathrm{NH}_{2} \mathrm{O}$ Payt-Rediation Oxidation in the Prexence of $\mathrm{O} .04 \mathrm{M}$ NaNO, at Various NaOH concentrationg and Absimbed Dosers.

\begin{tabular}{|c|c|c|}
\hline 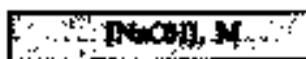 & 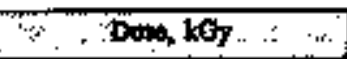 & $\because \quad \times 10^{4}, \tan E^{2} \operatorname{son}^{2}$, \\
\hline 0.5 & 0 & 6.1 \\
\hline 05 & 2.5 & 6.1 \\
\hline 0.5 & 5 & 6.0 \\
\hline 0.5 & 10 & 6.9 \\
\hline 0.5 & 20 & 5.8 \\
\hline 4 & $\overline{0}$ & 3.6 \\
\hline 4 & 5 & 2.5 \\
\hline 4 & 10 & 3.6 \\
\hline 4 & 20 & 2.2 \\
\hline 8 & 0 & 1.8 \\
\hline 8 & 5 & 1.5 \\
\hline 8 & 10 & 1.9 \\
\hline 8 & 20 & I.J \\
\hline 15 & 0 & 2.1 \\
\hline 15 & 2.5 & 4.4 \\
\hline 15 & 5 & 1.0 \\
\hline 15 & $10 \hat{0}$ & 1.0 \\
\hline 15 & 20 & 0.3 \\
\hline
\end{tabular}


Table 5-5. Pans, $\mathrm{V}$, of Te, $\mathrm{O}_{3}+4 \mathrm{H}_{2} \mathrm{O}$ Post-Rafiation Oxdation

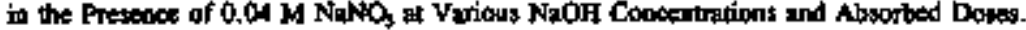

\begin{tabular}{|c|c|c|}
\hline Prow, $\mathbf{M}: \cdots$ & " & $\checkmark \times 19$, bod Lets \\
\hline 0.5 & 2.5 & 5.7 \\
\hline 0.5 & 5 & 5.1 \\
\hline 0.5 & 10 & 5.7 \\
\hline 0.5 & 20 & 5.3 \\
\hline 4 & 0 & 3.9 \\
\hline 4 & 10 & 4.3 \\
\hline B & 0 & 4.0 \\
\hline 8 & 2.5 & 4.9 \\
\hline 8 & 10 & 2.8 \\
\hline 1 & 20 & 4.0 \\
\hline 15 & 0 & 2.4 \\
\hline 15 & 2.5 & 1.6 \\
\hline 15 & 10 & 0.8 \\
\hline
\end{tabular}


Table 5-6. Rettes, $\mathrm{V}$, of $\mathrm{TCO}$, af, $\mathrm{O}$ Post-Radiation Oxidaton in the Presente of $0.05 \mathrm{M} \mathrm{NaNO}$ a Various NrOH Concentritions and Absorted Doses.

\begin{tabular}{|c|c|c|}
\hline 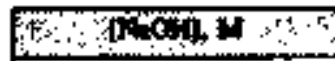 & 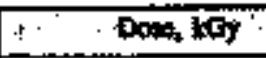 & 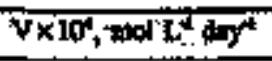 \\
\hline 0.5 & 0 & 5.0 \\
\hline 0.5 & 2.5 & 4.4 \\
\hline 0.5 & 5 & 3.0 \\
\hline 0.5 & 10 & $\$ .4$ \\
\hline 0.5 & 20 & 3.2 \\
\hline 4 & 0 & 3.7 \\
\hline 4 & 2.5 & 3.4 \\
\hline 4 & 5 & 3.2 \\
\hline 4 & 10 & 3.0 \\
\hline 4 & 20 & 2,8 \\
\hline 8 & 0 & 2.9 \\
\hline 8 & 2.5 & 2.8 \\
\hline 8 & 5 & 2.7 \\
\hline 8 & 10 & 2.5 \\
\hline 8 & 20 & 2.1 \\
\hline IS & $\overrightarrow{0}$ & 1.5 \\
\hline 15 & 2.5 & 1.5 \\
\hline 15 & 5 & 1.3 \\
\hline IS & 10 & 1.1 \\
\hline IS & 20 & $0 . \mathrm{B}$ \\
\hline
\end{tabular}




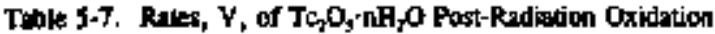
in the Presence of $0.06 \mathrm{~N} \mathrm{NaNO}$ al Vyious $\mathrm{N} 2 \mathrm{OH}$ Concentrations and Aberted Doses.

\begin{tabular}{|c|c|c|}
\hline 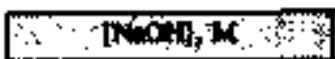 & 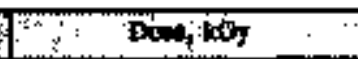 & 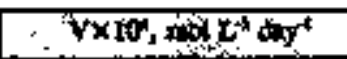 \\
\hline 0.5 & 6 & 4.5 \\
\hline 0.5 & 2.5 & 4.9 \\
\hline 0.5 & 5 & 5.1 \\
\hline 0.5 & 10 & $\$ 9$ \\
\hline 0.5 & 20 & 4,4 \\
\hline 4 & 0 & 4.3 \\
\hline 4 & 2.5 & 4.2 \\
\hline 4 & 5 & 4,0 \\
\hline 4 & 10 & 3.9 \\
\hline 4 & 20 & 3.9 \\
\hline 8 & 0 & 2.8 \\
\hline 8 & 2.5 & 3.0 \\
\hline 8 & 5 & 3.2 \\
\hline 8 & 10 & 3.0 \\
\hline 8 & 20 & 3.0 \\
\hline is & 0 & 1.7 \\
\hline 15 & 2.5 & 1.4 \\
\hline I5 & 5 & 1.0 \\
\hline 15 & 10 & 1.1 \\
\hline 15 & 20 & 0.8 \\
\hline
\end{tabular}




\section{WHC-EP-OQQI}

Toble 5-8. Fates, $V$, of TeO $\cdot \mathrm{nH}_{3} \mathrm{O}$ Post-Redifrion Oxidation

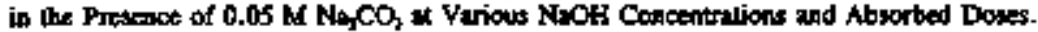

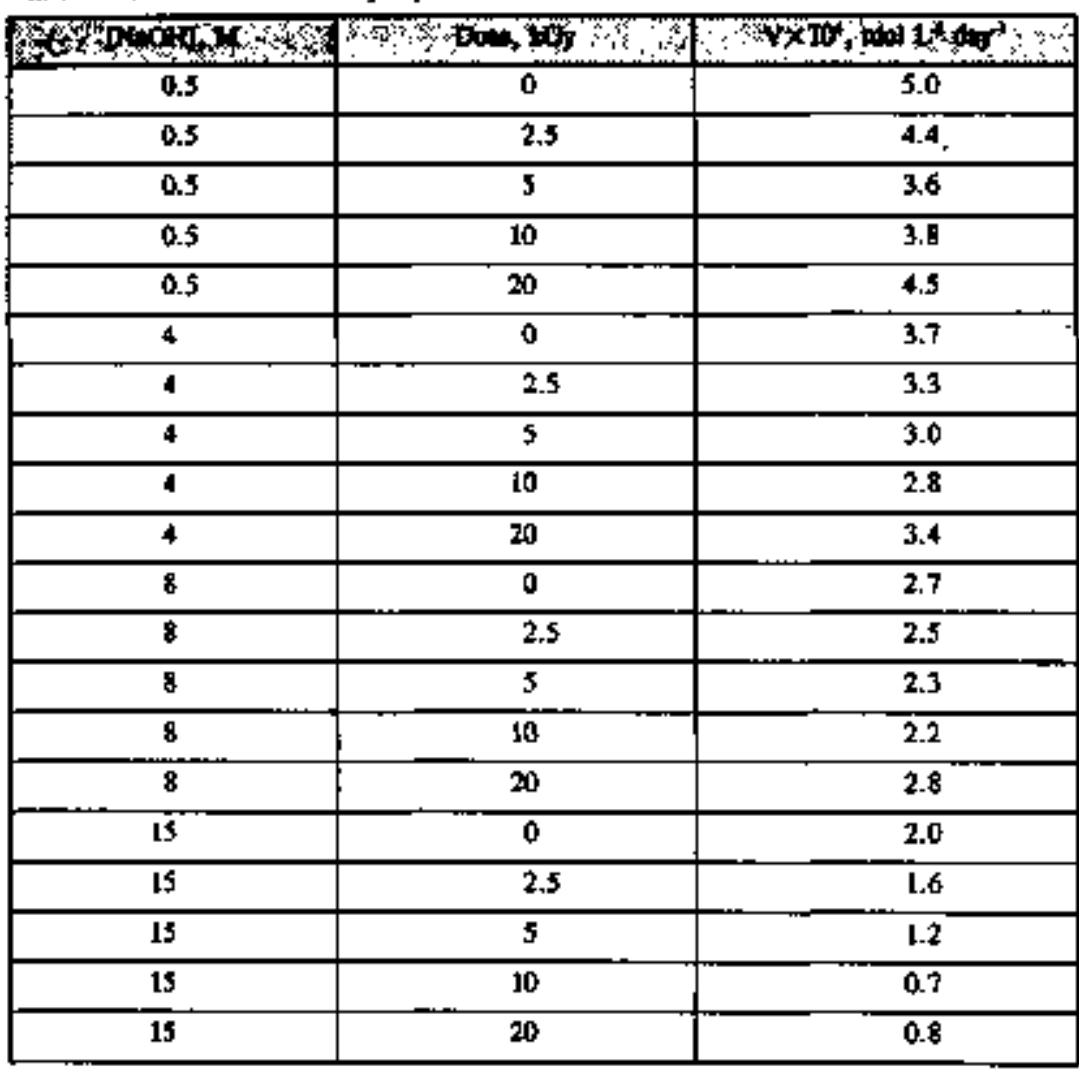


Trable 5-9, Raves, $\mathrm{V}$, of $\mathrm{T}_{\mathrm{C}_{2}} \mathrm{O}_{5}-\mathrm{nH} \mathrm{H}_{2} \mathrm{O}$ Pott-Rediation Oxidation th the Presence of $0.05 \mathrm{M} \mathrm{NgCO}$, at Yariout NoOts Coucentratons and Absorbed Doses.

\begin{tabular}{|c|c|c|}
\hline 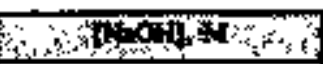 & 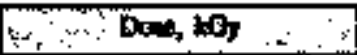 & 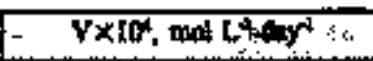 \\
\hline 0.5 & 0 & 5.8 \\
\hline 0.5 & $\overline{2.5}$ & 4.3 \\
\hline 0.5 & 10 & 3.3 \\
\hline 0.5 & 20 & 4.1 \\
\hline 4 & 0 & 4.0 \\
\hline 4 & 2.5 & 3.7 \\
\hline 4 & 5 & 3.2 \\
\hline 4 & 10 & 2.8 \\
\hline 4 & 20 & 3.0 \\
\hline 8 & 0 & 2.5 \\
\hline 8 & 2.5 & 2.3 \\
\hline 8 & 3 & 2.2 \\
\hline 8 & 10 & 2.0 \\
\hline 8 & 20 & 2.0 \\
\hline 15 & $\dot{0}$ & 1.4 \\
\hline$\overline{15}$ & 2.5 & 1.6 \\
\hline I5 & 5 & 1,5 \\
\hline 15 & 10 & 1,0 \\
\hline 15 & 20 & 1.1 \\
\hline
\end{tabular}




\subsection{CONCLUSION}

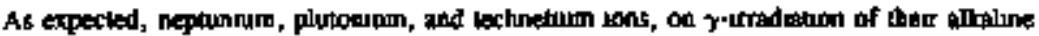

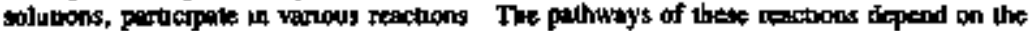

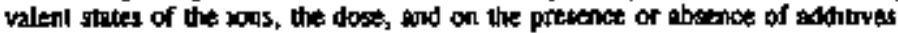

Neptonum(VI) is redued intally to Np(V) and, at lugher dosis, to Np(TV) The reduction

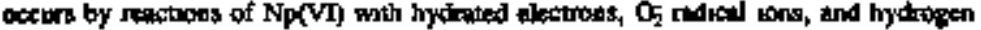
peroude to torm $\mathrm{Np}(\mathrm{V})$ and by contanted tiactoon of $\mathrm{Np}(\mathrm{V})$ wilh hydraled electrons

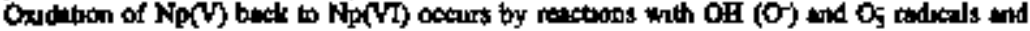

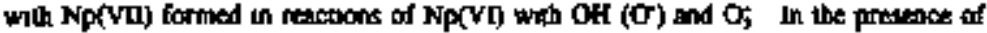

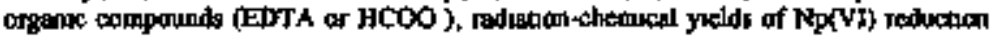
increase conuduably

The Np(TV) generated in these reducloons forms a finely dispersed surpenswon thal coagulates

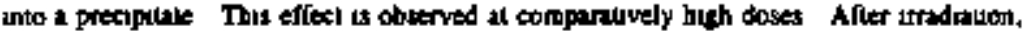
Np(TV) is alowly oxidized to Np(V) by heterogeneous reactons with almosphenc oxygen discolved in solvotion and by hydrogen peroxide accumulated in amall concenurations by irrediation

Lake Np(VD, Np(V) is reduced by irratialion The reductron occurs by tetactom of Np(V) Whih hydrated electrons Suspeasons and precaptaks conkunung No(TV) tue observad at bowts doses than in the case of Np(VI) The Np(V) peroxo coutplex is abservet in the

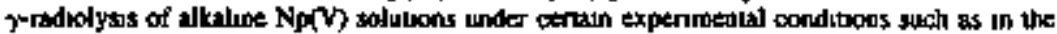
presence of autrite [remarimbly, the Np(V) petono complex is tot observed in the

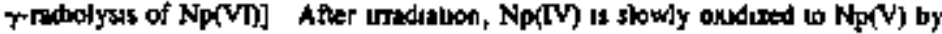
almosphenc oxygen and, postbly, by hydrogen peroxite

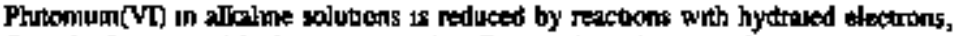
$O_{2}$ radicol wos, and bydrogen peroxide The produci plukndum(V) is upstable. ditproportioneteng to Pu(IV) and Pu(Vl) Bacaute PuhTV' hydrowde is unsoluble, Anely

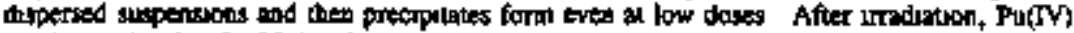

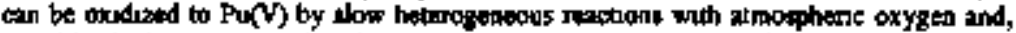

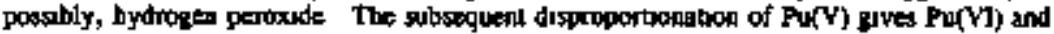
apgin Pri(T)

Techrotrum(VII) in the absence of pectal addiewes is not reduced by y-fatholysus nI alkalunc solutrons Reduction is abserved in the presence of addituves that can scavenge OH (0) rodecals Such scavengers unciude alcohols (E 8 , wrthanod and iertbulanol) and EDTA 


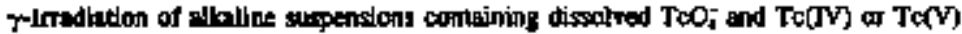
hydroxide solids gives rise to redoction of the To(VII). Oxidations of the Tc(TV) and To(V)

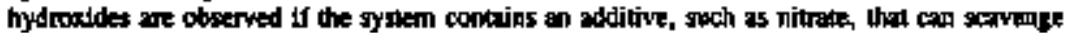

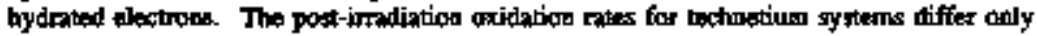
sliginly from the mines observed in unirradialed simples. 
WHC.EP.4901

\subsection{ACKNOWIEDGKMFNTS}

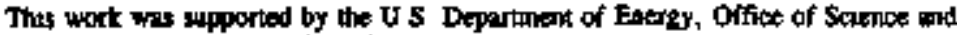

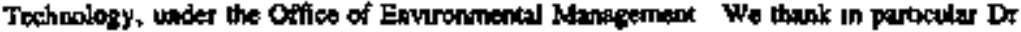

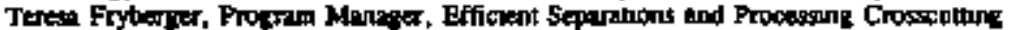

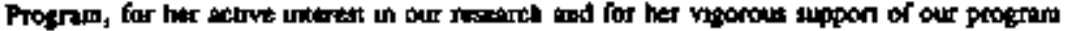
*t the Instante of Phyreal Chemstry, Rution Acadeny of Sciences We also thank Dr

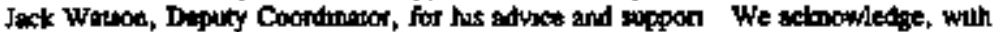

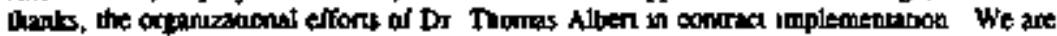

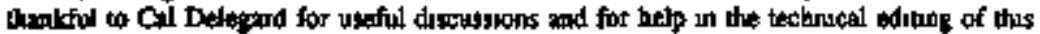
docoinent

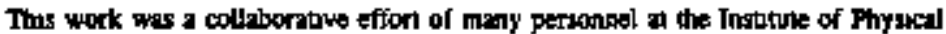
Chemustry Dr $\Lambda \mathrm{V}$ Gogolev lod the stuches of $\gamma$-radoolysas of nepanoum and plutonum

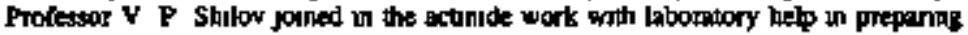

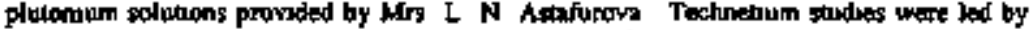
Dr S V Kryukctikg He was jouned by Dr V N Chulkov Mrs L, I Belyatera provided help in prepartion of the wechneaum samptes and it analybcal measureanents The

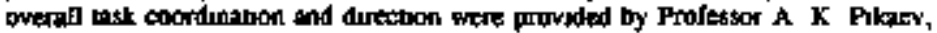
Correspondung Meqniuer of the Russyan Academy of Sciebces 
Thit page intentionedly keft blank. 


\section{M.0 REFERENCES}

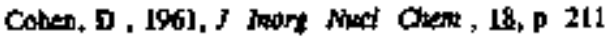

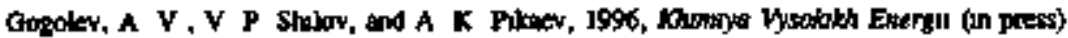

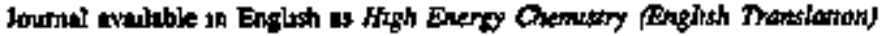

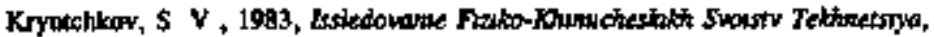

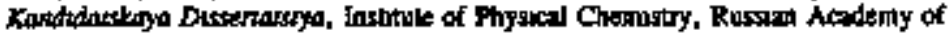
Sevences, Mowow, (in Rustain) Englest Tule The Sady of Physical-Chenacol Properives of Techuenum. AhD Thess

Shalow, V P, N N Krou, S V Knylchion, A Yusov, N Budaniseva, A Gamov,

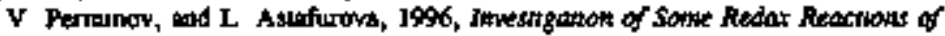

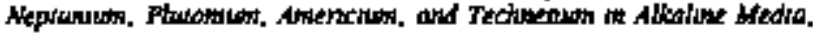
WHC EP-0896, Westunthous: Hanford Company, Ruchland, Wastungion, USA

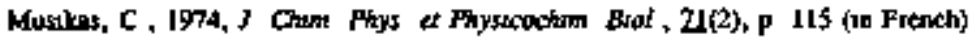

Mustat, C , I971, Radlostien Rodioana' Len , I. P 375 (In French)

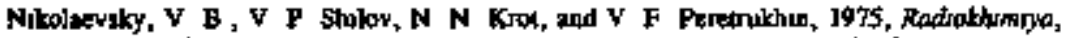

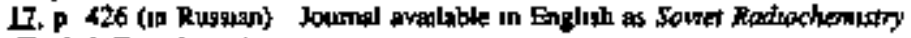
(Englush Thanslanion)

Peretrukhnn, V F, S V Kryutchkov, V I Suln, I G Tananaz, V I Bejyook, $\checkmark$ E Troshna, S I Ushakov, and $M$ S Gngor'ev, 1996, Dexemananon of the

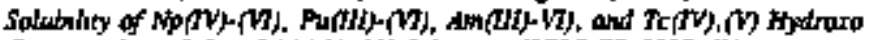

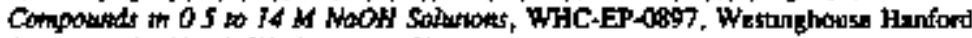

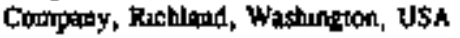

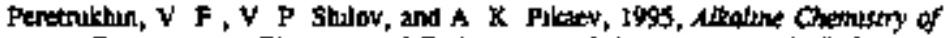

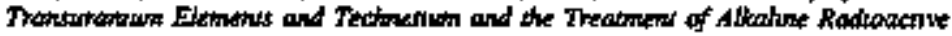

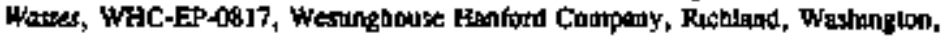
USA

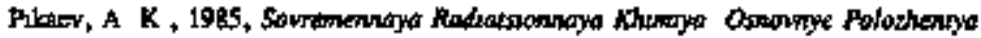

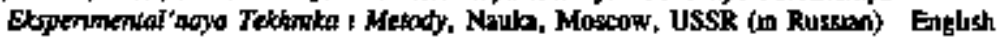

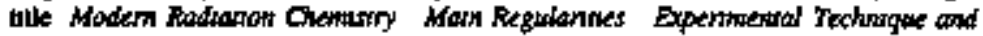
werhads

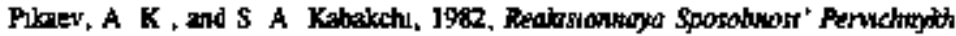

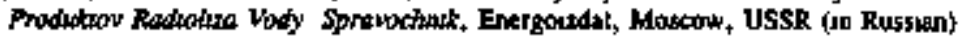

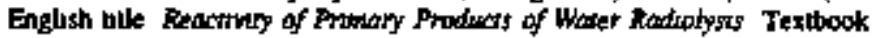




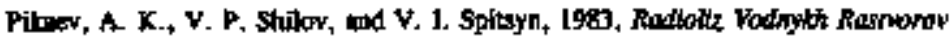
Lantanidov i Atariadov, Nanker Moscow, USSR (th Ression). Avalithle in Englth as

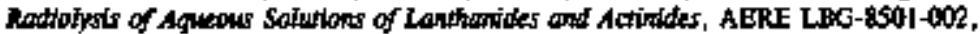
Atomb Energy Reteanch Estublisbmenl, Harwell, UK, $19 \mathrm{gS}$.

Pilonev, A. K., S. V. Kryutchloov, A. F. Kuzine, and V, J. Sphtsyn, t977, Dokd whad. Hapt

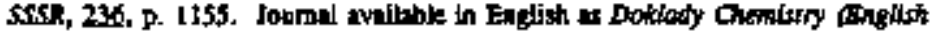
Thensiantond.

Sembort, G., J. Katz, and L. Morss, Eds., 1936, The Choningy of the Actioride Elengers, Chepen and Finll, 1.d., London, UX, New York, New York, USA. 


\section{DLSTRIBUTYON}

Number of Copizer

CEFSIIV

$?$

」

2

2

\section{DOMESTIC}

Amanne Nationgl Labogakncy

9700 S. Coss Ave.

Argome, I. 60439

E. P. Horwitz

K. L. Nagh

D. T. Reed

M. J. Steindler

D. M. Strachen

J. C. Sullivan

Technical Library

Ebrida Sale Undyectily

Department of Chemigtry, B]64

Talkhasiee, FL 32306-I096

G. R. Oroppls

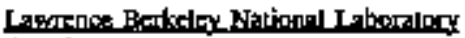

one Cyckolron Roed

University of Calliomia

Berkeley, CA 94720

Technical Libtary

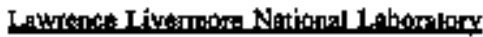

P. O. Box 808

Livturnore, CA 94550

2. Chiba

Techarkal Library 


\section{DISTRIBUTION}

Slombithe of Copies

\section{OFESTE}

4

Los Alamos Nhtional 1 d boratory

P. O. Bor 1669

Los Alamos, NM 87545

N. C. Schroedet

z. V. Svitre

1. A. Wort

Techndeal Library

7

Oak. Ridat Nationd L Laboratory

P. O. Bax 2000

Oal Ridge, TN 37831

J. T. Bell

NS 6223

W. D. Bond

MS 6355

E. Z. Eran

MS 6ats

C. P. McGinnis

L. M. Toth

MS 6268

J. S. Watson

MS 6227

Technical Library

I

SAIC

S\$S Quince Orchard Roed, Suite 500

Gailherstourg, MD 20878

Wiag Rot

2

Sandia National tolboratory

P. 0. Box [66]

Lot Alarnog, NM 87545

\$. F. Narsh

MS ESOI

Technical Libray 


\section{DESRIBUTION}

\section{Number of Copies}

\section{GESIIE}

4

了

2

I

Inizersity of Tonosestes

1

1
Department of Chemaisiry

Knoxville, TN 37996

J. R. Pelersan

Sprongah River Tachmigal Cenutet

P. O. Box 616

Aiken, SC 29108

D. T. Hobby

D. G. Karraker

M. C. Thompson

Techriegl Libraty

Thomps Albert and Asrocizten Ine: 34931 U.S. Highway I9 Noath

Suile 205

Plam Hator, FL 34684

T. E. Albert

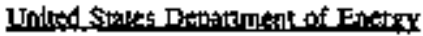

17\$ \$ Middlebarook Road

Trevion I Equilding

Germantown, MD 200874

K. Gerdes

Tectainal Library

Wrate Boliay Instipule

555 Quince Orchard Road, Suike 600

Galthersburtis, MD 20978

Lan Tasker

W. W. Schiul2

5314 Arbuskos Count

Albuqquerçue, NM \&87111
T73-A

$\pi 3-H$ 


\section{DLSTRIBUTTON}

Nimba of ciatits

OESSTTE

1

J. L. Swrinsar

1318 Cotionwood Drive

Rtchloid, WA 9952

OFESTIE

DIIERNATIONAL

1

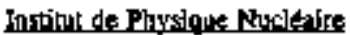

B.P, $\mathbf{N}^{*}$ ]

Orsay Cedex, France F-91406

F. Dayid

I

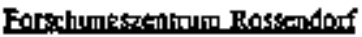

Instipul fut Radiontionte

Postizh 510119

Dresden, Demman D.01314

H. Nisgche

36

Instinute of. Phyteisal Chemistry

Busstan Academs of Selureces

31 Leniniky Prospekt

Mosoow, Russin 117915

L. N, Aslaf:40y4a

V. 1. Belyaeva

A. A, Bessontor

N. Budantseva

I. Chanshnikoya

V. N. Chulkow

A. Getrion

A. V. Gogotev (\$)

N. N. Krol

S. V. Kryukhkor (5)

V. F. Perelrukhin

$\checkmark$. Permines

A. K. Pikney (10) 


\section{DISTRIBUTION}

\section{Whmber of Conpies}

C55Tाए

Insilute of Phystad Chamistry

Buttina Acartcmy of Stivences (Contimsed)

V. P. Shitgy

V. I. Sitin

I. G. Tanaraey

A. Yusoy

E. M, Zatharowa

Texbrical Library

ONSITE

19

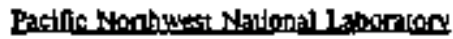

D. L. Blanchard

P7.25

G. N. Brown

P7-25

$Y$. Chen

K2-40

N. G. Collor

K2-40

S. K. Fadelf

Pา-72

K. F. Feignter

B1-II

A. R. Fetimy

K9-77

T. Fryberger

K2-20

T. E. kones

K6-51

B. W. Kultand

PT-75

W. L. Kuhn

K2.21

D. E. Kurath

P?.20

G. J. Lumbetta

P7-25

T. C. Maili

P7-07

D. Rai

KQT

1. Raso

KQT

B. M. Rapto

P7.25

J. L. Byen

P7.25

D. W, Wester

K7.74

PNNL Teebnical Files

K]-1I

Honford Technical Library

PB-S5 


\section{DISTRIBUTION}

\section{Number of Copies}

ONSIIE

1

10

45

\section{SAIC}

D. J. Swatibere

KB-SD

$\mathrm{KB}-\mathrm{St}$

KE-30

KB-50

57.50

A5-52

B4-55

K\&-50

KD-50

K5-51

A. 1.65
63-21

ST-14

T5-12

T5-09

15.22

T609

H6-34

म6. 34

S5-13

R5-49

H5. 61

T6-30

TS-12

T6-0\%

L5.55

T5.12

T6-50

T6-16 


\section{DLSTRIBUTHON}

Number of Orpins

ONSTIT

Whtringhimet Hanfoed commany (Continued)

D. L. Herting

T6-09

B. E. Hey

T6-09

R. C. Foyt

H5. 49

J. R. Jewett

T6 -09

R. A. Kirborite

H5-27

M. J. Kketn

B5-27

M. J. Kupser

B. G. Laurom

H5-27

G. T, MacLean

RI-108

J. C. Person

H5-61

W. I. Powell

T6-09

D. A. Reysolds

H5. 49

I. L. STippern

R2-11

J. P. Sloughter

T6-50

D. J. Washeafeldicr

R2-54

Document Processing Center

HS-27

Central Piks

A3.94

A3-BB 


\section{WHC-EP-0901}

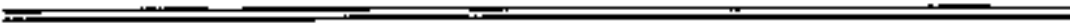

This page intentiondly left blontk.

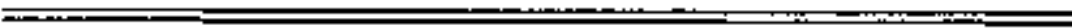

Distr-is 